


\section{WORLD BANK KNOWLEDGE SHARING AND REUSE INCENTIVE FRAMEWORK}




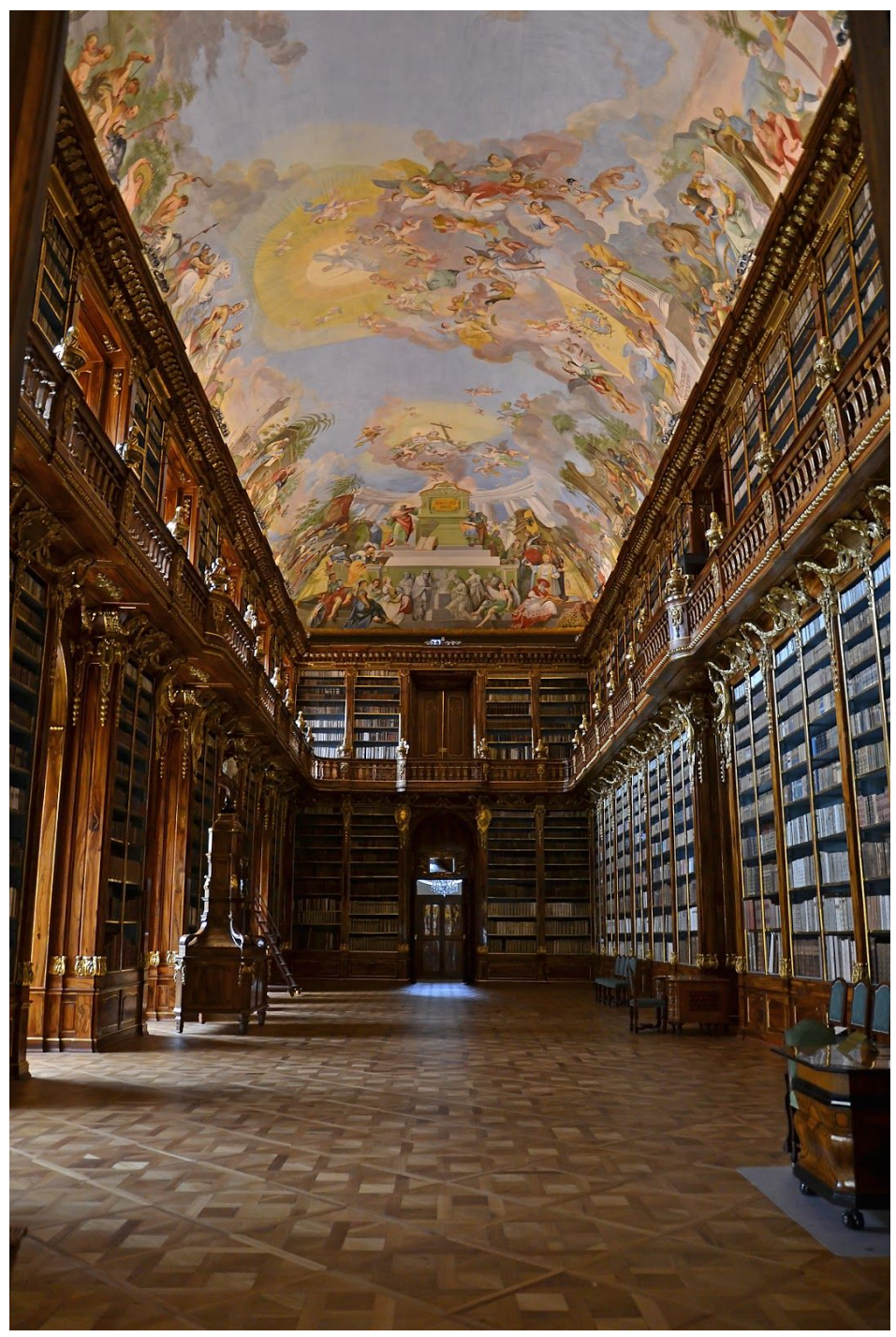

WORLD BANK KNOWLEDGE-SHARING AND REUSE INCENTIVE FRAMEWORK 
(C) 2019 International Bank for Reconstruction and Development / The World Bank

1818 H Street NW

Washington DC 20433

Telephone: $202-473-1000$

Internet: www.worldbank.org

This work is a product of the staff of The World Bank with external contributions. The findings in this study are currently positioned to represent those of the World Bank. While the IFC was involved in this study, this was limited to more consultative capacity as well as some participation in the qualitative and quantitative research streams. This study is therefore currently being positioned to represent only the World Bank, with the option remaining to revisit and refocus the content to reflect that of the IFC either exclusively or as part of a WB solution.

The World Bank does not guarantee the accuracy of the data included in this work. The boundaries, colors, denominations, and other information shown on any map in this work do not imply any judgment on the part of The World Bank concerning the legal status of any territory or the endorsement or acceptance of such boundaries.

\section{Rights and Permissions}

The material in this work is subject to copyright. Because The World Bank encourages dissemination of its knowledge, this work may be reproduced, in whole or in part, for noncommercial purposes as long as full attribution to this work is given.

Any queries on rights and licenses, including subsidiary rights, should be addressed to World Bank Publications, The World Bank, 1818 H Street NW, Washington, DC 20433, USA; fax: 202-522-2625; e-mail: pubrights@worldbank.org.

Cover art: Strahov library in Prague @ diabolique04 on DepositPhotos.com 


\section{Contents}

$\begin{array}{ll}\text { Highlights } & 1\end{array}$

Introduction to the Incentive Framework Toolkit for Behavioral Change 2

Illustrative Example of the Incentive Framework Toolkit in Action 2

$\begin{array}{ll}\text { Key Takeaways } & 7\end{array}$

$\begin{array}{lr}\text { Abbreviations } & 9\end{array}$

1. Introduction to Knowledge Sharing and the Incentive Framework 10

Identifying the Most Impactful Knowledge-Sharing Behaviors 13

A Behavioral Approach to Understanding Knowledge Sharing in the WB Context 15

2. What is Facilitating or Hindering Knowledge Sharing at the Bank? 16

Key Findings: Knowledge sharing overall 16

Key Findings: Key Desired Behaviors (KDBs) 17

$\begin{array}{ll}\text { 3. Theoretical Background-Uncovering the Framework } & 20\end{array}$

Defining the Behavioral Drivers and Incentives $\quad 20$

Driver: Linking knowledge sharing to self-development 20

Incentives:

Desire for confidence $\quad 21$

Desire for accomplishment 21

Desire for personal recognition/visibility 22

Desire for status 23

Desire for individual-group value alignment 24

Driver: Making knowledge sharing more social 25

Incentives:

Desire for inclusion 25

Desire for social support 26

Desire to follow formal norms 26

$\begin{array}{ll}\text { Desire for participation in management } & 27\end{array}$

Desire for consistency with beliefs and actions 28

Driver: Making knowledge sharing easier $\quad 29$

Incentives:

Ease of remembering information 29

Ease of identifying information $\quad 30$

$\begin{array}{ll}\text { Ease of processing information } & 30\end{array}$ 
References

Appendix I: Intervention Examples

Appendix II: Incentive Framework Wheel

Appendix III: Stock-taking - Current Incentives across the WB 


\section{Highlights}

This document presents an Incentive Framework aiming to improve knowledge sharing (KS) and reusing behaviors at the World Bank. Given the nature of the Bank's work, evidence suggests that effective and efficient knowledge sharing might be the biggest predictor of success. To approach KS in a holistic and evidence-based manner, past work was built on by assessing the psychological drivers of and barriers to knowledge sharing. The authors carried out a behavioral diagnostic that included: interviews with 22 external organizations; a qualitative survey with 50 World Bank staff members; a quantitative survey with 256 World Bank employees; and an extensive literature review yielding a list of 225 incentives across 15 different fields. This work confirmed the existence of five key structural barriers to knowledge sharing that had been identified in previous World Bank work:

1. Training: Lack of formal training opportunities [85\% of staff agreed]

2. Performance evaluation: KS unconnected to Overall Performance Evaluations (OPEs) [82\% of staff agreed]

3. Time allocation: Insufficient time to execute KS [80\% of staff agreed]

4. Prioritization: Lack of KS prioritization by managers [80\% of staff agreed]

5. Budgeting: Lack of explicit budgeting to support KS [73\% of staff agreed]

In addition, 5 critical behavioral barriers were identified:

1. Endowment effect: Lack of personal ownership [89\% of staff agreed]

2. Social norms: Insufficient KS norms [85\% of staff agreed]

3. System justification bias: Insufficient peer pressure [85\% of staff agreed]

4. Salience: Lack of KS visibility [80\% of staff agreed]

5. Discounting: Disconnect between KS and career goals [78\% of staff agreed] 
To address these barriers, three drivers of change were defined that are likely to lead to more knowledge sharing in the World Bank. The drivers were identified by leveraging established behavioral science frameworks, reviewing literature, and undertaking a deep dive into incentives at other organizations. The drivers are as follows:
A. Making knowledge sharing more social
B. Making knowledge sharing easier
C. Linking knowledge sharing to self-development

This report presents these drivers, as well as the associated incentives, and readers will learn how to transform these insights into concrete actions to help their teams share knowledge better and more often, and ultimately to use KS to achieve better outcomes for their teams, the Bank, its clients, and partners. While the rest of the report takes a deep dive into the framework, it starts by walking the reader through a simple use case of the Incentive Framework Toolkit.

\section{Introduction to the Incentive Framework Toolkit for Behavioral Change}

This section provides the reader with an example for applying the incentive framework toolkit. The framework outlines three steps to for achieving behavioral drivers, each of which has corresponding incentives found to motivate various behaviors in the World Bank (WB) context. The example draws from specific key desired behaviors (KDBs) related to Knowledge Sharing (i.e. handover package creation, joint mission engagement, creating a list of the top 10 issues to tackle, sharing short relevant punchy (SRP) stories, and proactive sign-ups for trainings). However, the underlying logic in this is that steps taken to encourage these KS behaviors can also be applied to a wide range of other behaviors in the Bank. Readers are provided with the tools to turn desired behavioral goals into actionable plans through the proposed interventions. A guide for implementing and evaluating the interventions is provided in Section 4.

\section{Illustrative Example of the Incentive Framework Toolkit in Action}

The incentive framework leveraged in this scenario is presented visually in Figure 1. At the center of the framework are the three main drivers of change, which summarize the forces that trigger changes in behavior. The thirteen more specific incentives (motivators of behavioral change) are presented in the outer ring of the framework. The framework is structured to work from the middle outward. Each incentive can then be 
matched by a specific intervention which will help activate that desired behavioral change. Such intervention examples are listed in Appendix I.

The first step in designing an intervention is to identify the driver of change.

Each driver has a set of associated incentives which can be leveraged in order to activate the drivers of change. The example situation below the framework wheel will walk the reader through an application of the incentive framework. 


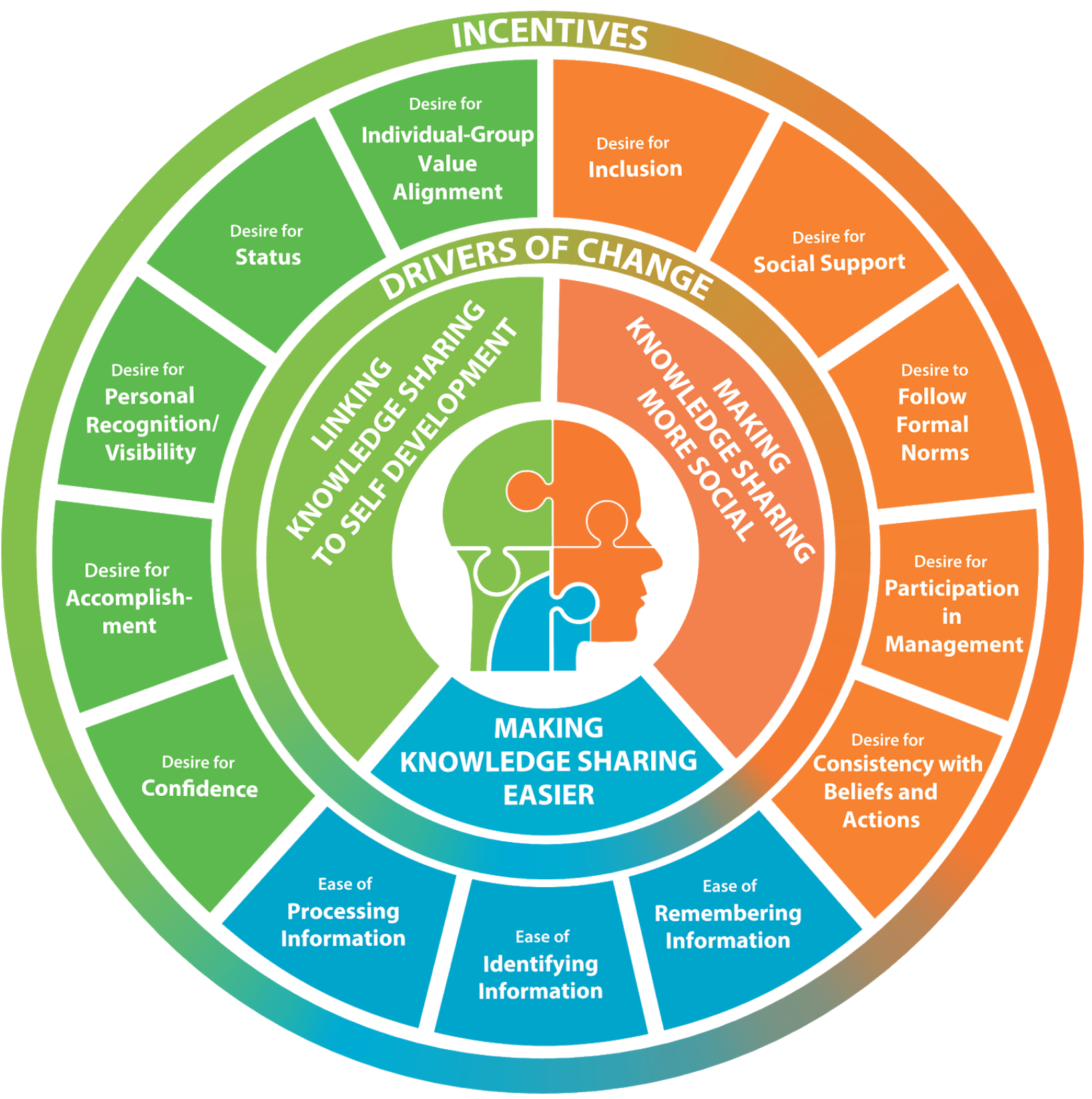

FIGURE 1: Three key drivers of behavioral changes to promote knowledge sharing at the World Bank, and associated incentives. 
xample situation: suppose that a senior staff member (Norma) wants to increase uptake of a useful report about the Bank's micro-financing initiatives and encourage knowledge-sharing efforts more generally within her team. The microfinance report was originally brought to her attention by a more junior staff member, who used the insights from that the report to help solve a key project challenge and thereby helped unlock an additional critical impact that the World Bank had hoped to have on a similar project in Afghanistan.

Using the Incentive Framework Toolkit, what steps might Norma take to increase uptake of the report within the WB, thereby promoting both knowledge sharing and reuse more generally along the way? In the section below, positive behaviors that she could take are outlined; and how they support the three key drivers of the framework are explained.

\section{Step 1: Link Knowledge Sharing to Self-Development}

Self-actualization is a component of self-development and refers to the human desire to develop oneself and realize one's potential. The desire for self-actualization is a powerful force for behavioral change. Users of the incentive framework toolkit can leverage this driver by connecting individual-level values and concerns to the impact that they themselves have on their peers and their work. To accomplish this, individuals need the opportunity to connect their wider goals to their daily actions.

First, by using the Incentive Framework Toolkit, Norma finds that a behavior can be promoted by showing how it delivers value. Specifically, she learns that individuals want to see their skills and efforts reflected in the impacts that they help bring about. Individuals want to recognize themselves in their work and have others recognize them in their work as well.

Accordingly, Norma writes a short e-mail that details: (a) the key insights that the junior team member extracted from the report, (b) the skills and efforts that the junior staffer deployed in translating those insights into the context of the project at hand, and (c) the impacts that these insights unlocked for the project, the team, and the stakeholders. She sends the e-mail to her director, with the junior staff member in $\mathrm{CC}$, and encourages the director to share this message with the wider team by posting it to the unit bulletin board. 
By articulating explicitly how the junior team member's skills and efforts contributed to project impacts, Norma is tapping into the desire for accomplishment. Sending the e-mail to her director and having it posted to the open bulletin board also taps into the desire for personal recognition/visibility. These actions help to promote the use of the report specifically and the sharing of knowledge in general.

\section{Step 2: Make Knowledge Sharing More Social}

A social knowledge-sharing environment is one that facilitates psychosocial belonging. Psychosocial belonging refers to the feeling of inclusion generated by being connected to or participating in something larger than ourselves. In the workplace, individuals can become fixated on the details of their specific projects, in turn losing sight of the greater picture and their role in it. Users of the incentive framework toolkit can instill a sense of inclusion and belonging among their peers by increasing social support and facilitating the creation of inclusive norms and spaces. This example illustrates how a practitioner can promote psychosocial belonging in simple ways.

Soon after promoting the report, Norma notices increased discussion of the report as well as sharing of other materials among her colleagues. Recognizing these signs of early adoption, she wants to take a second step to reinforce these emerging behaviors. Consulting the toolkit, she learns that she can promote the use of the report, along with other knowledge-sharing activities, by making knowledge sharing more social. Individuals want to participate in social groups, which creates a sense of belonging to something larger than themselves.

Drawing on her new understanding of behavior change, Norma presents on the topic at the next unit meeting. She articulates how the junior staff member used the insights from the report to unlock huge impacts, along with some candidate ideas that she herself has developed since then for using the report in future projects. She notes that these candidate ideas are still in development and offer the opportunity to other unit members to help her shape how these ideas will be applied in a high-profile upcoming project.

By showing that she herself is engaging in the same kinds of behaviors that she is promoting - rather than merely talking about their importance-Norma is tapping into the desire for consistency with beliefs and actions. In taking the time to formulate and deliver her presentation, she is communicating that this report and other knowledge-sharing activities are important to the identity of the unit, which will prompt others to follow suit as they seek to satisfy their desire for inclusion in the group. Finally, by offering knowledge sharing as an avenue for shaping a defining piece of work for the group, Norma is tapping into the desire to participate in management. 


\section{Step 3: Make Knowledge Sharing Easier}

Making knowledge sharing easier relies on reducing the cognitive load associated with mental tasks. Cognitive load refers to any amount of working memory resources; it can be used to refer to the resources that an individual has available to them or to the demands that a given cognitive task will require in order to be executed. When information is easier to recall from memory, or the information needed to complete a task is easily available, the cognitive load decreases. The tendency for individuals to seek out mental "shortcuts" to reduce this load can be a powerful source for behavioral change. Practitioners can leverage this incentive by changing things in the environment to reduce the cognitive load of their peers. The key insight here is to make information highly visible, accessible, memorable, and easy to use. In the scenario, these principles are implemented in simple ways.

With the microfinance report now often coming up in conversation, along with other key insights from other knowledge-sharing activities, Norma wants to cement these new behaviors into the new normal practice within the unit. Drawing once again from the Incentive Framework Toolkit, she learns that she can promote these new practices by making knowledge sharing easier to use. Individuals will draw on the information that promises value at a low cognitive cost.

Norma summarizes the microfinancing report in five key bullets, highlighting one key term in each bullet by applying a bold style and an eye-catching color, and building these five key terms into a catchy acronym-POWER. She stores the summary and acronym in the digital knowledge database for her team, tagging her entry with key terms ("development," "microfinance", etc.) with the titles of projects in which it has been applied, and sends an e-mail to her colleagues that includes the summary as well as a link to the entry in the unit's portal.

By summarizing the key points for her colleagues in plain language, Norma increases the ease of contextual processing of information. The use of bold style and color makes the key messages visually evident at a glance in the summary, and the storage of the summary in the online system with relevant metadata tagging makes it easy to retrieve with relevant searches, all of which increase the ease of cognitive processing of information. Finally, the simple and catchy acronym increases the ease of retrieval of information. 


\section{Key Takeaways}

The hypothetical case outlined above presents one possible way in which WB staff could use insights gleaned from the Incentive Framework Toolkit to achieve behavioral change within knowledge-sharing contexts. The rest of this report will describe the framework in more detail, providing background information on the process undertaken to create it, the three key drivers identified as most impactful, and the associated framework of knowledge-sharing incentives (Figure 1) generated based on these findings. The intention is that future work will build on these recommendations, designing real-world interventions grounded in both the structural and behavioral reality at hand, to enable the WB to improve its knowledge-sharing activities and ultimately increase the organization's impact.

\section{Acknowledgments}

This report was co-authored by Jakob Rusinek (DECKM), Patrick Burkhalter (DECKM), Sekoul Krastev (The Decision Lab), Jayden Rae (The Decision Lab), Brooke Struck (The Decision Lab) \& Dan Pilat (The Decision Lab), with close support by Macha Petronella Kemperman (DECKM), Marielle Montenegro (The Decision Lab), and Edmond Dizon (The Decision Lab). Sincere gratitude is extended to the Working Group members for their contribution to the development of the framework including: Zeina Afif (EMBED), Angela Armstrong (SLCEN), Manfred Cowan (HRDPA), Abigail Dalton (EMBED), Camino Hurtado (DECCE), Brett Libresco (OPSRA), Shalindra Mylvaganam (SCCFM), Neesham Spitzberg (CIRCT), Liudmila Uvarova (EFIPM), and Ingo Wiederhofer (SEAS1). Oversight and overall support were provided by the Steering Committee including World Bank Group members: Margot Brown (DECKS), Varun Gauri (EMBED), Maria Gonzalez de Asis (SLCSO), Valerie Hickey (SLCEN), Emily Kay Hutton (HRDPA), Chiyo Kanda (OPSRA), Sebastian-A Molineus (Country Director), David Rosenblatt (DECKS), Marc Sadler (SCCFM), Susan Shen (SEAS1), Renos Vakis (EMBED), and Kelly Widelska (IFC).

The additional WB staff are recognized for having contributed to the research in this report (alphabetically by surname): Cristian Aedo, Anna Akhalkatsi, Arusyak Alaverdyan, Ousman Abdulahi Ali, Ghassan N. Alkhoja, Khalid Bin Anjum, Elmas Arisoy, Angela G. Armstrong, Oscar Avalle, Federico E. Baechli, Siaka Bakayoko, Oleksii Balabushko, Raul Antonio Barrios, Harold Bedoya, Robert C. M Beyer, Kristyna Bishop, Charles Victor Blanco, Christian Bodewig, Matilde Bordon, Javier Botero Alvarez, Chadi Bou Habib, Kamel Braham, Alejandro Cedeno, Yang Chen, Samuel Thomas Clark, Nestor Coffi, Adrian 
Howard Cutler, Upulee Iresha Dasanayake, Sebastien C. Dessus, Ioannis Dimitropoulos, Ousmane Dione, Avani Dixit, Aletheia Amalia Donald, Jesse Jon Gerome Doyle, David Duarte, Mark Andrew Dutz, Sameh El-Saharty, Mourad Ezzine, Marcelo Jorge Fabre, Siosaia Tupou Faletau, Homa-Zahra Fotouhi, Xavier Furtado, Claire Jeanne Chantal Galpin, Natalija Gelvanovska-Garcia, Ann Glauber, Dmytro Glazkov, Mike Goldberg, Ramesh Govindaraj, Ruth Grove, Rebekka E. Grun, Pankaj Gupta, Sherif Bahig Hamdy, Phillip Matthew Hannam, Inaam Ul Haq, Valerie Hickey, Bert Hofman, Martin Holtmann, Edward Hsu, Ergys Islamaj, Serdar Jepbarov, Hillary C. Johnson, David James Kaczan, Pierre Joseph Kamano, Chrissie Kamwendo, Alain-Desire Karibwami, Asmeen Khan, Ashish Khanna, Kamleshwar Khelawan, Jay-Hyung Kim, Andrew Kircher, Alexander Kremer, Anila Kuka, Gabriel Lara Ibarra, Alessandro Legrottaglie, Zijun Li, Jose R. Lopez Calix, Gladys C. Lopez-Acevedo, Wilfred Lus, Ian Robert Georges Macpherson, Nguyen Mai, Massimo Mastruzzi, Carole Megevand, Snezana Mitrovic, Sebastian Molineus, Mirwais Farooq Mujaddidi, Naveed Naqvi, Mantsebo Moipone Amelia Ndlovu, Zacharie Ngueng, Giang Thi Huong Nguyen, Allan Tobalbal Oliver, Nadege Orlova, Harry Patrinos, Gabriel Penaloza, Sangeeta Carol Pinto, Patrizia Poggi, Bigyan B. Pradhan, Neeraj Prasad, Ellena Rabeson, Martin Raiser, Diego Juan Rodriguez, Carlo Maria Rossotto, Michal Rutkowski, Artessa Saldivar-Sali, Yara Salem, Maryam Salim, Geremie Sawadogo, Steven Schonberger, Ozan Sevimli, Elad Shenfeld, Roberto Ferreira Lima Silva, Janmejay Singh, Gayatri Singh, Viktoriia Siriachenko, Alphonse Soh, Lars M. Sondergaard, Mona Sur, Nobuyuki Tanaka, Jeffery Tanner, Mohammad Muntasim Tanvir, Mar Mar Thwin, Goran Tinjic, Siv Tokle, Robert Johann Utz, Gonzalo J. Varela, Son Thanh Vo, Svetlana Vukanovic, Sonya Woo, Christina A. Wood, Yaya Yedan, Fabrizio Zarcone, and Ming Zhang. 


\section{Abbreviations}

$\begin{array}{ll}\text { ACS } & \text { Administrative and Client Support } \\ \text { ADM } & \text { Accountability and Decision-Making } \\ \text { AI } & \text { Artificial Intelligence } \\ \text { CD } & \text { Country Director } \\ \text { CM } & \text { Country Manager } \\ \text { COM-B } & \text { Capability Opportunity Motivation - Behavior (Framework of } \\ & \text { Behavior Change) } \\ \text { DECKM } & \text { Development Economics Knowledge Management } \\ \text { IEG } & \text { Independent Evaluation Group } \\ \text { IT } & \text { Information Technology } \\ \text { ITS } & \text { Information Technology Systems } \\ \text { KAP } & \text { Knowledge, Attitudes and Practices } \\ \text { KDB } & \text { Key Desired Behavior } \\ \text { KM } & \text { Knowledge Management } \\ \text { KPI } & \text { Key Performance Indicators } \\ \text { KS } & \text { Knowledge Sharing } \\ \text { KSB } & \text { Knowledge Sharer Badge } \\ \text { KTP } & \text { Knowledge Transfer Point } \\ \text { GD } & \text { Global Director } \\ \text { GL } & \text { Global Leads } \\ \text { GP } & \text { Global Practices } \\ \text { GSG } & \text { Global Solutions Group } \\ \text { HR } & \text { Human Resources } \\ \text { HRBP } & \text { Human Resources Business Partner } \\ \text { OKR } & \text { Open Knowledge Repository } \\ \text { OPE } & \text { Overall Performance Evaluation } \\ \text { OPCS } & \text { Operations Policy and Country Services } \\ \text { PM } & \text { Program Manager } \\ \text { QER } & \text { Quality Enhancement Review } \\ \text { SC } & \text { Steering Committee } \\ \text { SD } & \text { Senior Director } \\ \text { SM } & \text { Senior Management } \\ \text { SMS } & \text { Short Message Service } \\ \text { SRP } & \text { Short Relevant Punchy } \\ \text { TDA } & \text { Trade and Development Agency } \\ \text { TTL } & \text { Task Team Leader } \\ \text { ToR } & \text { Terms of Reference } \\ \text { VP } & \text { Vice President } \\ \text { WB } & \text { World Bank } \\ & \end{array}$




\section{INTRODUCTION TO KNOWLEDGE SHARING AND THE INCENTIVE FRAMEWORK}

Identifying the Most Impactful Knowledge-Sharing Behaviors

A Behavioral Approach to Understanding Knowledge Sharing in the WB Context

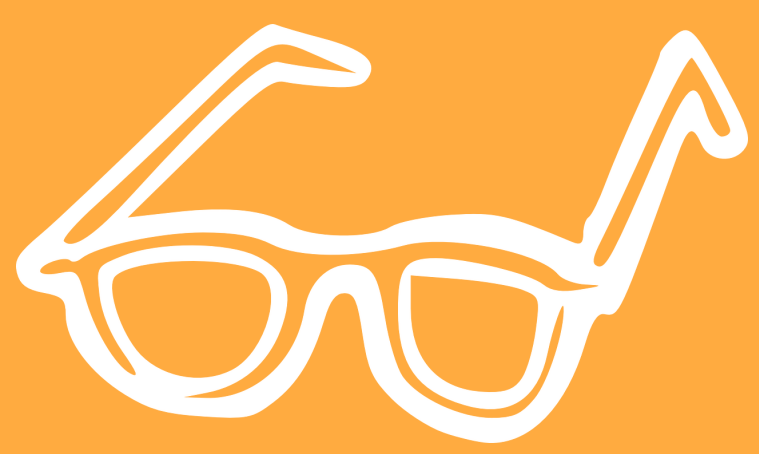




\section{Introduction to Knowledge Sharing and the Incentive Framework}

This report focuses on knowledge sharing (KS) and reuse at the World Bank. Sharing knowledge amongst staff across different contexts is essential to facilitate successful working relationships, staff transitions, and organizational continuity. In organizational cultures where KS is prioritized, individual wisdom can be transferred to others in the institution, which ultimately creating creates a competitive advantage (Figure 2). Knowledge Management (KM) and KS are hyper-sensitive to the daily realities of the organization in which they take place, and must, therefore, be studied closely within their context of implementation. Therefore, any real-world implementation of effective KM must be tailored to the organizational and individual specificities of the World Bank.

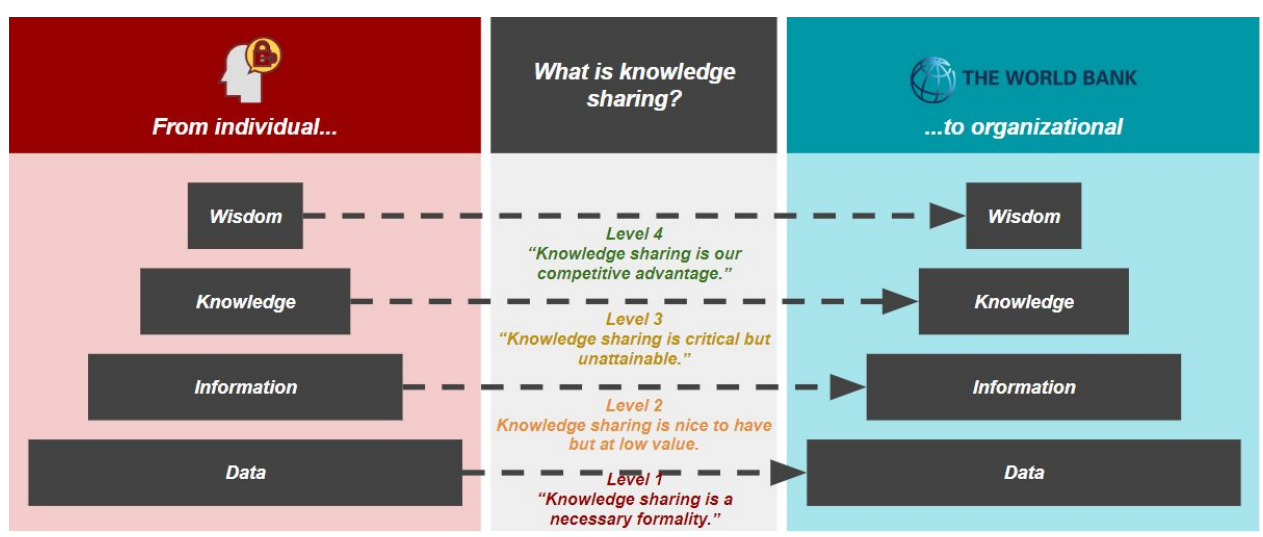

FIGURE 2: In organizations, KS often starts out as a formality. When individuals in the organization are empowered to share their wisdom with their peers, $\mathrm{KS}$ can be transformed into a competitive advantage.

One important component of accomplishing this effectively, which complements and builds on past work (Figure 3), is the creation of interventions that are based on evidence about what motivates people to behave the way they do within the context of the WB. 
Past work focused on ...

Identifying Knowledge Transfer Processes in the WBG: Specifically look at the WB operating model.

Describing Existing Gaps and Offering Recommendations: Focus on mechanisms for working across GPs and among GPs.

Theoretical Overview of Structural Barriers to Knowledge Sharing: Do a macro-level assessment of how well the World Bank's current operating model stimulates knowledge flow.

Analyzing Benefits of Knowledge Exchange for the WBG: Describe and assess the individual and group institutional and systemic implications.
Our work built on this by focusing on ...

Assessing Knowledge Sharing at the Individual Knowledge Transfer Point/Key Desired Behavior Level: Use behavioral diagnostic methodologies.

Tangible Interventions to Address KM Challenges: Employ 20 testable interventions developed to target the KDBs.

50+ In-depth Interviews and 256 Quantitative Surveys with WBG Staff: Uncover specific drivers and barriers through the Quant assessment.

Providing Tools to Realize the Benefits: Use implementation plans based on behavioral analysis tied to interventions.

FIGURE 3: The incentive framework builds on past work by the WB on knowledge sharing incentives. 
The process presented in this report, and the resulting incentive framework toolkit, aims to fill this gap by providing a strong basis for designing behavior-specific knowledge-sharing interventions. In order to accomplish this, the WB partnered with The Decision Lab. Together, desk research and qualitative work (the specific process can be seen in Appendix I) culminated in a quantitative survey that garnered responses from $256 \mathrm{WB}$ employees. The goal of the survey was to uncover the drivers and barriers within the WB for sharing knowledge. Additionally, the survey was designed to assess the beliefs and mindsets within the existing system to uncover potential leverage points for creating shifts in KS norms. Knowledge sharing involves knowledge flows from individuals to their peers. This process requires individuals to have mindsets inclined toward knowledge sharing, which is a process that can transform organizations (Figure 4).

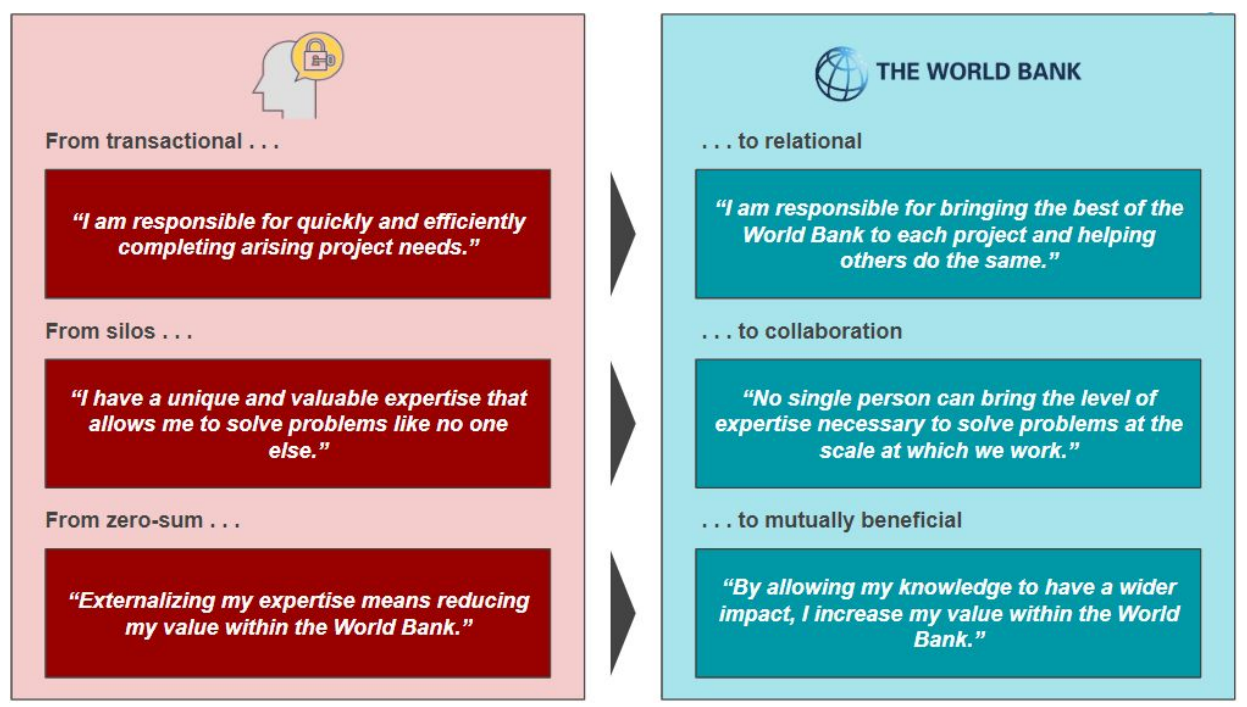

FIGURE 4: KS involves knowledge flowing from individuals to their peers. This process requires individuals to have mindsets inclined toward KS.

Establishing an organizational culture that values KS encourages and relies on a common value system where individual-level and organizational beliefs and mindsets are aligned (Figure 5). This alignment can be facilitated by incentivizing KS mindsets through incentive frameworks described in this report. 


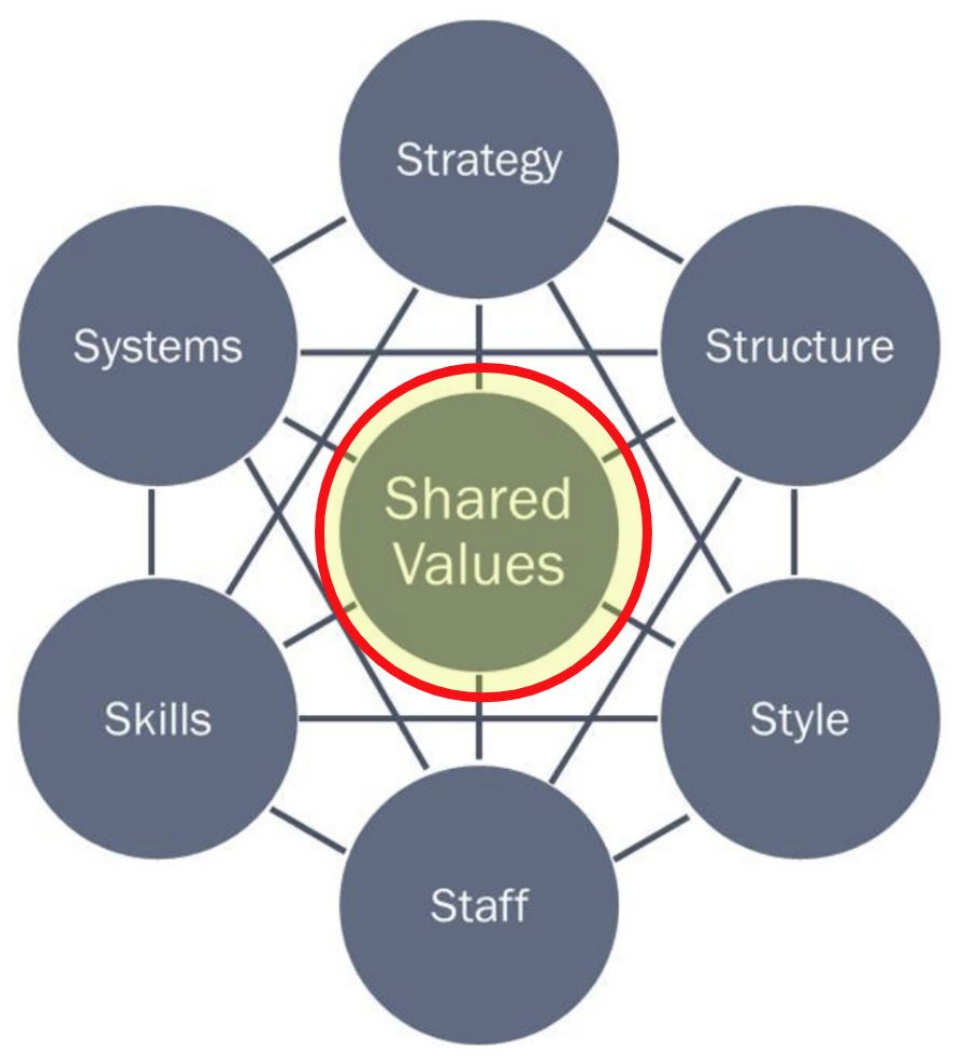

FIGURE 5: Creating organizational shifts begins with establishing a clear common value system that is based on shared beliefs and mindsets.

With these goals in mind, the body of this report is separated into two main sections. The first section assesses the primary barriers and drivers for knowledge sharing within the World Bank (which were the key insights distilled from the survey), broken down into findings regarding KS overall and findings regarding key desired behaviors specifically. The second section presents the framework for the Bank to design and implement interventions. These two main sections are followed by a summative conclusion.

There are also several appendixes to this report. Appendix I provides a more detailed process and methodology to explain in depth how this project was executed. Appendix II provides the interventions in a table format. Appendix III provides a complete list of references for this project.

\section{Identifying the Most Impactful Knowledge-Sharing Behaviors}

Given that knowledge sharing is a complex system of behaviors, a two-pronged approach was used to unravel it within the WB context. First, broad knowledge sharing was focused on and, second, knowledge-sharing behaviors considered particularly impactful by WB staff were identified. The process of analyzing the contextual realities of $\mathrm{KS}$ at the Bank and completing a behavior diagnostic involved 13 phases (Figure 6). 

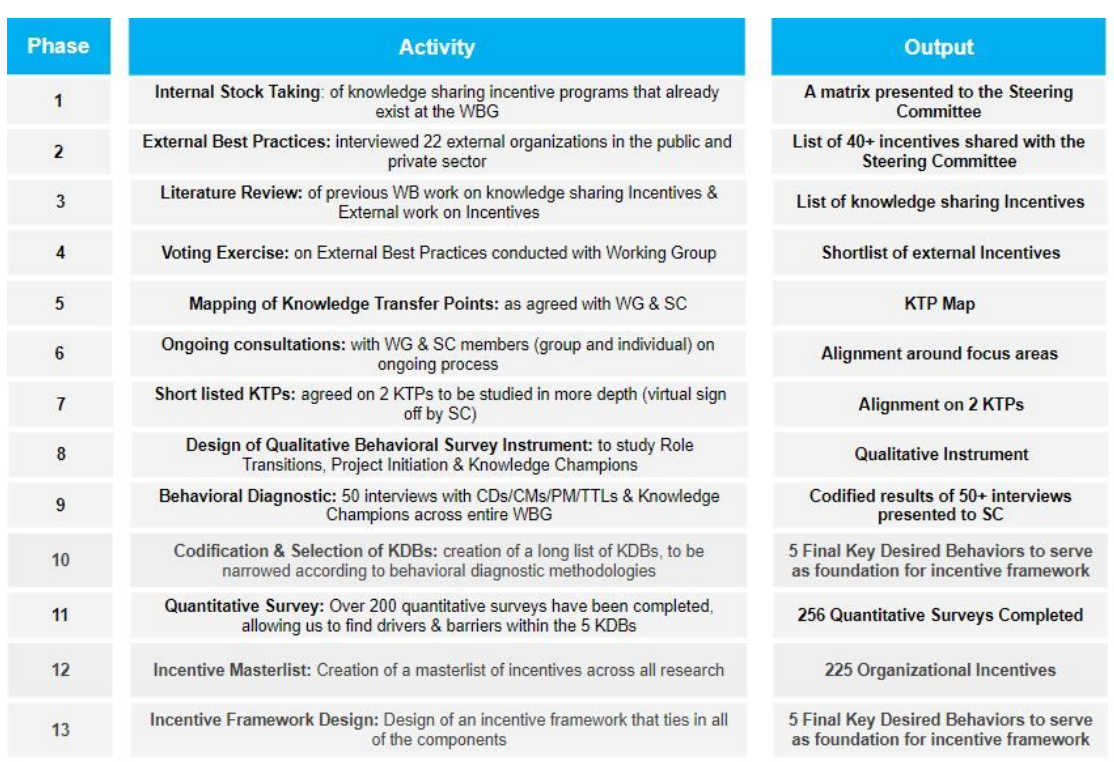

FIGURE 6: The incentive framework is a product of a 13-phase process involving desk and primary research, and quantitative and qualitative data analysis.

The five specific key desired behaviors (KDBs) on which the qualitative and quantitative work focused were:

1. Handover packages - Staff creates an adequate handover package 2. Joint missions - Outgoing Task Team Leader (TTL) goes on joint mission with incoming TTL

3. Top 10 issues to tackle - Staff creates a list of Top 10 issues to tackle during a position handover

4. Sharing short relevant punchy (SRP) pieces - Staff shares engaging content with colleagues

5. Proactive sign-ups for trainings unrelated to TOR - Staff engages in training unrelated to their Terms of Reference (ToR)

These KDBs were selected during an iterative process with input from WB staff members led by the KS Incentives Working Group and Steering Committee. The criteria for selecting these specific KDBs included diversity in the behaviors targeted and the potential impact of the behaviors on the outcome of World Bank operations. 


\section{A Behavioral Approach to Understanding Knowledge Sharing in the WB Context}

To develop the incentive framework toolkit, a study was undertaken to uncover the specific barriers and drivers to knowledge sharing behaviors within the World Bank. A survey was created to discover the psychosocial, behavioral, and structural barriers to effective knowledge sharing. The specific KDBs were used as examples in the survey to provide more generalizable insights for potential entry points into behavioral interventions (a full description of the survey methodology is located in Appendix I).

In summary, the results from the survey allowed for the identification of barriers and drivers for KS around these KDBs, and to measure the extent to which staff members felt these barriers and drivers were having an effect on their work. As shown in Appendix IIV, each barrier or driver was categorized as Physical, Social, Psychological, Automatic, or Reflective based on the behavior Change Wheel (COM-B) from Behavioral Science which is a rigorous method, validated scientifically through peer reviews, for characterizing and designing behavior-change interventions. The behavior change wheel uses the COM-B (capability, opportunity, motivation and behavior) model, which recognizes that behavior is part of an interacting system involving all these components. With the barriers and drivers identified in the survey and characterized according to the behavior Change Wheel, incentives and sample interventions were devised for each of the COM-B categories. 


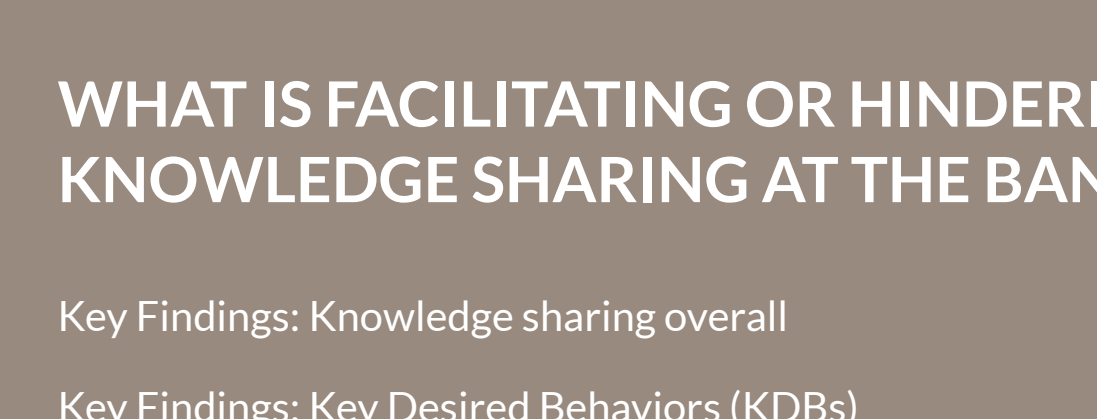

$\theta^{\prime}$ 


\section{What is Facilitating or Hindering Knowledge Sharing at the Bank?}

This section presents the key insights distilled from the survey of 256 respondents working at the WB. These findings are divided into insights about knowledge sharing overall in at the Bank, and targeted insights about the key desired behaviors tested.

\section{Key Findings: Knowledge sharing overall}

\section{Staff members want their project to succeed}

The first finding that stood out from the survey was that the vast majority of survey respondents (about 90\%) agreed ${ }^{[1]}$ that sharing knowledge about one's projects is important because staff members have a desire to see their projects succeed, even if the staff member themselves move on to another role before the project is completed. This sentiment is further confirmed by the weak level of support (less than 20\% agree) for the notion that sharing knowledge brings no personal benefit.

\section{Reciprocity encourages knowledge sharing}

Second, the vast majority of respondents (about 90\%) also agreed that sharing knowledge with colleagues is important, even if those colleagues are not also sharing knowledge in return. Indeed, even if knowledge sharing is viewed as important even in the absence of reciprocal sharing in turn from one's colleagues, most survey respondents $(66 \%)$ still indicated that when colleagues do share their knowledge, this motivates further sharing of knowledge. Apparently, reciprocity encourages knowledge sharing, even if it is not a necessary precondition for it.

\section{Staff are not concerned about the exclusivity of their knowledge}

In terms of structural incentives, only a small share of the respondents $(20 \%)$ felt that "giving knowledge away" was misaligned with one's own career incentives, suggesting that knowledge is not considered to be a resource with exclusive personal ownership. However, a notably larger share (nearly 50\%) felt that the structural incentives for knowledge sharing were aligned toward winning projects for one's own unit - there was significant agreement with the statement of: "mo strong incentive to share knowledge with other units."

[1] "Agreement" refers to those respondents who selected: "somewhat agree," "agree" or "strongly agree"; these responses equate to a 5 or higher on a 1-7 Likert scale. 
Sharing knowledge is challenging despite sufficient resource availability

Lastly, regarding opportunities to share knowledge, a large majority (about 75\%) acknowledged the importance of knowledge sharing but noted that other tasks were higher priorities "given the limited amount of time and budget available to dedicate to their own projects." These were not the only hurdles either; the majority (over 60\%) also agreed that sharing knowledge is challenging "even when sufficient time and budgets are provided." Sufficient time and budget are important structural features to promote knowledge sharing, but other barriers — structural and/or behavioral—also need to be identified and addressed.

\section{Key Findings: Key Desired Behaviors (KDBs)}

\section{Role transitions create unique KS challenges}

Looking across the respondents' assessments of the key desired behaviors, some clear messages emerge. First, survey respondents pointed out that there is no strong cultural convergence around knowledge sharing within the World Bank context. Only $40 \%$ of respondents agreed that they often see WB colleagues engaging in the highlighted KDBs. Engagement with "Top 10 issues" lists [KDB3] and with handover packages [KDB1] were both especially low, with less than $30 \%$ of survey respondents agreeing that they often see colleagues engaging in these behaviors. These findings reflect the existence of a pronounced $\mathrm{KS}$ challenge around role transition. On a more positive note, two-thirds of respondents $(66 \%)$ agreed that they often see WB colleagues engaging in joint missions [KDB2], and over half (52\%) agreed that they often see colleagues posting short, relevant punchy pieces [KDB4] as a mechanism to share knowledge.

\section{Time constraints are a key barrier to $\mathrm{KS}$}

A large share (80\%) of survey respondents agreed that having sufficient time would increase engagement in the KDBs. The value of sufficient time allocation from their manager was especially noteworthy for joint missions [KDB2], for which nearly $90 \%$ of respondents agreed that sufficient time allocation would increase engagement. Handover packages [KDB1] and top-10 issues lists [KDB3] could also be better supported through adequate time allocation, according to the large majority of respondents ( $80 \%$ or above), suggesting that time allocation might be one avenue to address the KS challenge noted above around role transition. 


\section{Technology systems can be an impediment to KS}

Regarding technological systems, more than one-third of respondents (38\%) felt that current WB technological systems himder staff from engaging in the KDBs. This finding was relatively consistent across the individual KDBs, though staff members generally felt less hindered by the WB technological systems for sharing short, relevant, punchy pieces [KDB4] and top 10 issues to tackle [KDB3], and generally felt more hindered in terms of handover packages [KDB1], joint missions [KDB2], and signing up proactively for unrelated trainings [KDB5].

In terms of behavioral approaches to increase engagement, a large majority (just over $85 \%$ ) agreed that "WB staff would be more likely to engage in [the KDB] if others around them engaged in it." This sentiment was especially strong regarding handover packages [KDB1] and posting short, relevant punchy pieces [KDB4], about which $90 \%$ or more of respondents believed that colleagues' engagement in these behaviors would help to increase the prevalence of the behavior overall. Very similar findings were obtained regarding the visibility of one's KS work. A majority (just over $80 \%$ ) agreed that WB staff would be more likely to engage in the KDBs if the output were seen and recognized by more colleagues. Once again, this sentiment was especially strong regarding handover packages [KDB1] and posting short, relevant punchy pieces [KDB4].

Respondents also overwhelmingly agreed (nearly 90\%) that "a positive and useful knowledge transfer experience" would encourage staff members to engage in more KS activity in the future. This sentiment was very pronounced for handover packages [KDB1] and joint missions [KDB2], though support was strong for the other KDBs also.

\section{Social environments can facilitate or hinder KS}

Taking the three previous results together, these findings highlight the strong potential of social factors to promote knowledge sharing within the World Bank. Employees are motivated to share knowledge when they see others around them doing so, when their own KS activities are visible to and recognized by others, and especially when they have had a positive experience sharing knowledge with Bank colleagues in the past. 
Intrinsic rewards motivate $\mathrm{KS}$ behaviors

Survey respondents clearly identified that intrinsic rewards hold key potential to increase engagement in the KDBs. Intrinsic rewards include incentives such as a sense of accomplishment, social recognition, or a feeling of ownership over one's work.

A clear majority (over $80 \%$ ) agreed that intrinsic rewards could be clear motivators, especially for joint missions [KDB2] for which nearly all respondents $(95 \%)$ agreed that intrinsic motivation could play an important role. Asked about two specific internal motivators, there tended to be agreement that a sense of ownership promotes engagement more than a sense of accomplishment.

However, results differed by intrinsic motivator and by KDB, suggesting that an across-the-board approach, using a single intrinsic motivator in all cases to increase engagement, may not produce uniformly successful results. Further experimental testing could be valuable to uncover which incentive would be most powerful to deploy in each area to optimally promote engagement.

\section{Extrinsic rewards complementary to other KS incentives}

When asked about more structural types of incentives (such as performance assessment criteria and monetary bonuses), respondents indicated that extrinsic rewards could also promote engagement. However, the responses are less clear and less consistent than the results for intrinsic rewards, suggesting that extrinsic rewards might be better suited to a complementary role to bolster intrinsic incentives. For example, respondents overwhelmingly agreed (over 90\%) that includes joint missions [KDB2] in performance assessment criteria could promote engagement, but they were divided (less than $45 \%$ agreed) on whether monetary bonuses would promote engagement in that same behavior.

\section{Intrinsic incentives more powerful than extrinsic ones}

Experimental research has demonstrated that the presence of a monetary incentive can crowd out a social norm (Sandel 2013). Accordingly, extrinsic incentives need to be deployed carefully to ensure that they do not displace (and therefore neutralize) intrinsic motivations. The survey results reported here suggest that - in the case of joint missions [KDB2] - the intrinsic motivation from a sense of accomplishment is much more powerful than the extrinsic motivation of a monetary bonus. If the existence of a monetary bonus inhibits WB staff members from feeling a sense of accomplishment in joint missions, the introduction of this extrinsic incentive could actually decrease engagement in the desired behavior. Reemphasizing the call above, well-designed experimental testing would be very important to ensure that behaviors are promoted through the optimal mix of incentives, because there is reason to believe that individual incentives might have interactive rather than summative effects. 


\section{THEORETICAL BACKGROUND-UNCOVERING THE FRAMEWORK}

Defining the Behavioral Drivers and Incentives

Driver: Linking knowledge sharing to self-development

Incentives:

Desire for confidence

Desire for accomplishment

Desire for personal recognition/visibility

Desire for status

Desire for individual-group value alignment

Driver: Making knowledge sharing more social

Incentives:

Desire for inclusion

Desire for social support

Desire to follow formal norms

Desire for participation in management

Desire for consistency with beliefs and actions

Driver: Making knowledge sharing easier

Incentives:

Ease of remembering information

Ease of identifying information

Ease of processing information

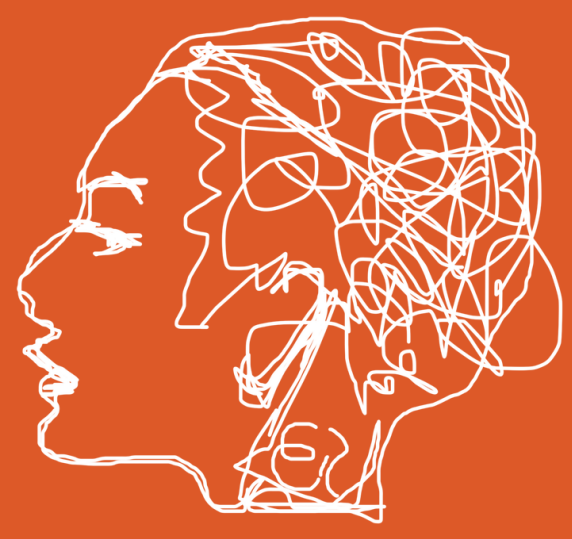




\section{Theoretical Background- Uncovering the Framework}

\section{Defining the Behavioral Drivers and Incentives}

This section defines the drivers of behavior and each individual incentive with supporting examples from the WB context. The individual incentives included in the framework were selected through using a variety of the following inputs: including case studies of external best practices, a comprehensive literature review, behavior change frameworks and qualitative interviews with WB staff (Figure 7).

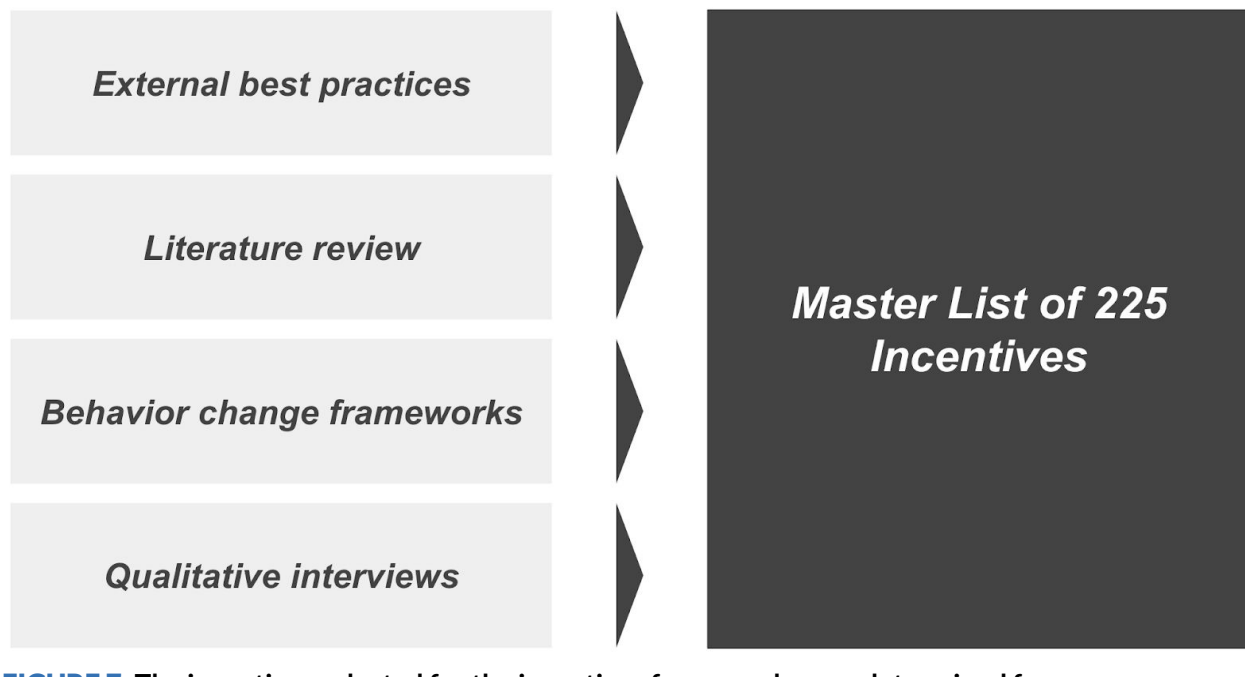

FIGURE 7: The incentives selected for the incentives framework were determined from a Mastermaster list of 225 incentives.

\section{Driver: Linking knowledge sharing to self-development}

The desire to develop oneself relates to realizing one's potential and is sometimes referred to as "self-actualization." Individuals have many ambitions for what they would like to see come to life in the world, and many skills to offer to bring those ideas to life. Two important dimensions to one's potential are: the vision that one has for the world around oneself, and the vision that one has for oneself as the architect and builder of that desired world. Self-actualization relates to both of these dimensions. People wish to see their vision for the world realized, and they wish to participate in that realization by making it their own and seeing themselves reflected in what they build. The desire for self-actualization is a powerful driver of behavior because it taps into a deep-seated sense of personal identity. This driver, which is stable over time, can be used to promote change that will be sustained in the long term. 


\section{Incentive: Desire for confidence}

Definition: Individuals wish to feel empowered and to believe that they can have an impact on the world around them and make a difference. Beyond this, they also seek a sense of control in how they can make the difference that they desire. This combination of both potential and control feed into a sense of confidence, which is the feeling that one's action will lead to the results that one seeks to bring about. This sense of confidence is a critical component in overcoming doubt, which can be an obstacle to one's actions.

WB context: As a global leader in world development, the Bank and its staff must have confidence in the work they do. Confidence in their work (as well as in the Bank's work in the world) means that staff will be able to share their viewpoints and their knowledge, communicating more effectively with their peers.

Example interventions applied to knowledge sharing: Individuals have more confidence when they are in an environment where they feel safe sharing their ideas and opinions. In the context of knowledge sharing, safe spaces are enabling environments where individuals seek out knowledge from others and share their own knowledge. A critical aspect of these safe spaces - which can be physical environments or online communities - is that they are overtly nonjudgmental, allowing Bank employees to openly discuss the gaps or limitations in their knowledge.

This open discussion of gaps or limitations is crucial. For those who are seeking knowledge, these gaps or limitations are an articulation of their needs. For those who are sharing knowledge, these gaps or limitations are an articulation of the extent to which their contributions can respond to those needs - and the extent to which they may require additional knowledge in order to be adequately addressed. If an employee recognizes a desire to increase their knowledge, there must be opportunities for employees to safely explore an avenue to do so. Safe spaces allow for knowledge to be explored and exchanged without threatening confidence (see intervention examples in AppendixI).

\section{Incentive: Desire for accomplishment}

Definition: In addition to having confidence that one's actions will lead to the outcomes one desired, individuals seek a sense of accomplishment. They want to feel that they can do something, and they want to actually deliver that something. Confidence can also be bolstered by accomplishment, because such achievements demonstrate to someone what one they are capable of, and thereby increases the confidence that one they can accomplish more again in the future. An incentive can drive behavioral change by tapping into the individual's desire for a sense of accomplishment: the feeling that they have achieved objectives that they set for themselves. 
WB context: It is a common assumption in an institutional setting that offers opportunities for upward mobility as a reward for strong performance, that a culture may become embedded where external motivations become the overriding drivers of activity, drowning out internal motivators. However, this assumption proves to be too simplistic. In the survey, $82 \%$ of respondents stated that they think other WB staff would be more likely to engage in the target behavior if it were tied to intrinsic rewards, such as a sense of accomplishment, which can act as a significant incentive to drive behavior among staff.

Example interventions applied to knowledge sharing: In institutional settings with a wide range of experience levels among staff, a sense of accomplishment can be instilled by senior staff members acknowledging more junior staff for their contributions to a key outcome. Specifically in the context of knowledge sharing, individual desire for accomplishment can be leveraged by prompting staff members to send "short relevant punchy" (SRP) pieces directly to their Director (with the staff member in $\mathrm{CC}$ ), pointing out the work that was done, the qualities that made this work noteworthy, and the outcomes that it helped to achieve (i.e., the impact), along with the name of the staff member who accomplished this task. Seeing the impact of their knowledge-sharing activities clearly articulated, along with the qualities that made their work so impactful, will help to solidify the sense of accomplishment in the employee's mind, especially because this articulation comes with the endorsement of a more seasoned and experienced colleague whom they respect. That the e-mail was sent to an even more senior colleague will also resonate with desires for personal recognition/visibility, which is the next incentive (see intervention examples in Appendix I).

\section{Incentive: Desire for personal recognition/visibility}

Definition: As noted above, self-actualization includes both the realization of one's vision for the world as well as one's active involvement in realizing that vision. In addition to these, an employee wants to be recognized for his/her contribution to these changes. Individuals want to see themselves reflected in the world around them, and they also want other people to see them reflected in their work. An incentive can drive behavioral change by tapping into the individual's desire for personal visibility: the feeling of being recognized in one's work by others, as one recognizes oneself. 
WB context: In the context of knowledge, behaviors relating to sharing knowledge are closely linked to the visibility an individual receives for engaging in knowledge sharing. This notion was confirmed in a survey delivered to WB staff in the context of knowledge sharing, where $80 \%$ of respondents agreed that other WB staff would be more likely to engage in the behavior if the output would be more visible (i.e., seen and recognized by a larger number of colleagues).

Example interventions applied to knowledge sharing: In the context of knowledge sharing, one potential intervention to leverage the desire for personal recognition/visibility is to provide senior staff with mechanisms for providing public recognition/praise to staff members for engaging in a specific knowledge-sharing behavior. The recognition could be delivered through a quote or comment on an employee profile, or another public forum. This intervention reinforces the notion that simple acts of recognition play an important role in validating desirable behaviors.

This intervention can also be combined with the previous interventions. If more senior staff members are notifying Global Directors about exemplary knowledge sharing activities, the notifications could be aggregated in a publicly visible forum. In brief, the notification e-mails that tap into the desire for accomplishment could constitute the primary feeder into a system that taps into the desire for recognition and visibility (see intervention examples in Appendix I).

\section{Incentive: Desire for status}

Definition: Individuals seek visibility, the recognition of others onto themselves in their work. At a broader level, someone may also hope that their collection of work reflects back on them. Someone may wish to be seen as the person who contributed to an individual achievement, as well as someone who achieved in a greater sense and above any specific piece of work. This is status: the presumption of one's competence by others, and the recognition and respect that comes with it. Status is often encoded in a symbol, such as a title, a certificate, or a medal. An incentive can drive behavioral change by tapping into the individual's desire for status: the feeling of being recognized and respected as someone who is competent.

WB context: Status in an institutional environment relates to one's own sense of identity. In a survey on the topic of knowledge sharing delivered to WB staff, $83 \%$ of respondents agreed that knowledge sharing benefits them personally. This finding suggests that WB staff acknowledge the importance of sharing knowledge to gain and maintain a sense of status in their work environment. 
Example interventions applied to knowledge sharing: An intervention to confer a sense of status on individuals in a working environment provides public recognition for knowledge-sharing activities. An implementation of conferring status could involve a "Knowledge Sharer Badge" displayed on the User Profiles of Staff once they engage in a set number/specific knowledge-sharing activities. Activities can be peer-recognized such as being acknowledged by another staff member (once again tying into SRP accomplishment e-mails), or system-recognized, as the badge can be awarded automatically when an activity takes place. By tying rewards (badges) to key knowledge-sharing behaviors, individuals gain status when they engage in target behaviors that the Bank wishes to promote among its employees (see intervention examples in Appendix I).

\section{Incentive: Desire for individual-group value alignment}

Definition: The desires for visibility and status highlight a critical social aspect to self-actualization: what one wishes to bring about in the world is as much for one's self as for others. The desire for individual-group value alignment is, therefore, crucial - that is, when someone wants collective values to be aligned with the values of those around him/her, as this alignment is an essential element for recognition and status. One wants to be recognized for having contributed to successful projects, and for being generally competent in contributing to overall success - but these must also involve work that is equally appreciated by others. An incentive can drive behavioral change by tapping into the individual's desire for their values to be aligned with the values of those around them: the feeling that one agrees with one's peers about such shared priorities.

WB context: Successful cross-sectoral and collaborative projects rely on team dynamics where individuals feel as though their values align with those of the group. In a survey completed by WB staff on the topic of knowledge sharing, $85 \%$ of respondents agreed that they believe their peer WB staff members would be more likely to engage in sharing knowledge if others around them were also engaging. This finding suggests that individuals are empowered when their actions, and the underlying values of those actions, align with those in the group.

Example interventions applied to knowledge sharing: Knowledge sharing is a process by which the knowledge an individual has acquired is shared and exchanged with their peers. This process is facilitated by the alignment of individual values with those of the group. An intervention to leverage this incentive in the WB setting is to publicly acknowledge the units whose members engaged in key knowledge-sharing behaviors. Whereas the previous interventions focused on the individual staff members, also highlighting success at the group level demonstrates their collective achievements - and thereby the 
value alignment between the groups and the individuals who make up the groups, and converge on knowledge sharing. When the unit as a whole is recognized, in addition to the individual members, it both highlights alignment of group values among members and encourages further alignment. A potential avenue of recognition could be delivered through a friendly ranking system based on specific knowledge-sharing behaviors that would be awarded monthly or quarterly (see intervention examples in Appendix I).

\section{Driver: Making knowledge sharing more social}

One's social activities are driven by the desire for "psychosocial belonging:" the sensation of feeling connected to or participating in something larger than ourselves. Like self-actualization, psychosocial belonging is strongly connected to a sense of identity. The difference is that whereas self-actualization refers primarily to the drive to define one's identity through one's work, psychosocial belonging refers primarily to the drive to define one's identity through one's community. Self-actualization and psychosocial belonging come together where work and community overlap.

Several features characterize the types of relationships with one's community members that support a sense of belonging. The relationships must be based on concern for the well-being of other community members, stable, and reciprocal, and the contact must be sufficiently frequent. The individuals within the group must also hold a shared perception about their group interactions; for instance, the actions must be both fair and seen to be fair, by everyone involved. The desire for knowledge sharing to be more social and psychosocially belonging is a powerful driver of behavior because it taps into a deep-seated sense of personal identity, which is quite stable over time. This driver can be used to promote change that will be sustained in the long term.

\section{Incentive: Desire for inclusion}

Definition: A core ingredient for psychosocial belonging is group membership. Individuals seek to be included as members of a collective group and to sustain their membership. It is their inclusion in the group that forms an important part of their identity as individuals. An incentive can drive behavioral change by tapping into an individual's desire to be a member of the group: the feeling that they are part of something greater than themselves.

Example interventions applied to knowledge sharing: Managers and senior staff play key roles in fostering an inclusive environment. Knowledge-sharing behaviors take place in environments where individuals feel that these behaviors are standard practice, especially among the leaders of the group. An intervention to leverage the desire for inclusion involves senior staff publicly and visibly engaging in knowledge-sharing activities themselves. Senior staff could attend trainings that are not directly related to their role, as a way to 
round out their skill sets. Participating in these trainings amongst less-senior members could demonstrate to the wider body of staff the value of KS, as could testimonials or synopses of learning (delivered at departmental meetings or via e-mail). By setting an example, senior staff demonstrates that KS activities are valuable enough to warrant the attention of the entire organization and everyone in it, regardless of their role or seniority (see full intervention examples in Appendix II).

\section{Incentive: Desire for social support}

Definition: Group membership provides the sense that one is participating in something that exceeds oneself. The effects of this group membership are that members act in the service of the group's collective goals and that the group acts in the service of the goals of each member. In brief, the group provides an important source of support for its members; this support can include both practical and emotional elements. An incentive can drive behavioral change by tapping into an individual's desire to receive that support: the feeling they are supported by the people around them and the group in which they participate.

WB context: Core values of the World Bank include empowering others and respecting differences, which form the basis of strong social support networks. As an organization that relies on effective and open teams, social support is a conduit for facilitating positive and lasting relationships. In a survey delivered to WB staff on the topic of knowledge sharing, $87 \%$ of respondents agreed that those who had a positive and useful knowledge-transfer experience in the past are more likely to engage in a target behavior. This suggests that receiving social support for a behavior creates a sense of validation and makes similar future activities more likely.

Example interventions applied to knowledge sharing: Within the Bank context, resources or mentorship programs specifically focusing on knowledge-sharing activities (such as handover package creation) could be provided. Such an intervention would give staff members - especially the more junior staff members - an opportunity to form positive connections with colleagues at the Bank, connections that can act as social support mechanisms when employees have questions about how to share knowledge. The positive association of social support with knowledge sharing will catalyze a favorable attitude among staff members toward KS activities (see intervention examples in Appendix I).

\section{Incentive: Desire to follow formal norms}

Definition: Group membership comes with certain structures that govern it, usually including both formal and informal norms. Accordingly, one's desire to sustain membership in a group will express itself practically as a desire to follow the norms of the group, especially the more formalized and explicit norms. 
One They will also feel a sense of desire to be seen following the norms of the group; that is, members must demonstrate to themselves and to one another that they are following the norms, as these behaviors are key markers of group membership. An incentive can drive behavioral change by tapping into an individual's desire to follow the formal norms of their group and to be acknowledged as such: the feeling that they are enacting the group's governing paradigm, thereby demonstrating their membership in and support of the group.

WB context: Institutions such as the World Bank are governed by formal norms that allow the behavior of its employees to be, to an extent, orderly and predictable. These formal norms ensure that there is continuity in the organization over time despite the reality of incoming and outgoing personnel. Additionally, formal norms in the World Bank create structures for staff to seek guidance in and familiarity with each other throughout their term - even if they change roles in the organization.

Example interventions applied to knowledge sharing: Each staff member in the WB has pre-established activities they must complete to fulfill the expectations of their role. Creating formal norms around desirable behaviors are is a strong force for those behaviors to be prioritized and exercised by staff. In the context of knowledge sharing, the incentive of desire to follow formal norms can be leveraged by making available a 'Knowledge Sharing Chargeback Code' as a formal process for engaging in activities such as creating handover packages (see full intervention examples in Appendix II).

\section{Incentive: Desire for participation in management}

Definition: As noted above, there are important overlaps between self-actualization and psychosocial belonging; the desire to participate in management is one juncture where this overlap is apparent. One desires to follow the norms that govern the behavior of group members (as this membership is a contributing component to one's identity), and one also desires to shape the norms that govern the behavior of group members (as a site of one's work, and thus a representation of oneself in what is accomplished). The opportunity to participate in shaping those norms is also a reflection of status and personal visibility. An incentive can drive behavioral change by tapping into an individual's desire to participate in managing the group of which they are a member: the feeling that one they have an active role to play in defining the group in which one they participate, and through which one that individual defines one's their own identity.

Example interventions applied to knowledge sharing: Leveraging the desire for participation in management activities is a powerful force for encouraging a range of behaviors. In the context of knowledge sharing, providing an opportunity for former and new management to connect and discuss their portfolios creates an enabling environment for former staff to go on a 
joint mission with succeeding staff. This intervention would empower managers to play an active role in managing relationships between individuals, and potentially among projects (see intervention examples in Appendix I).

Incentive: Desire for consistency with beliefs and actions

Definition: While psychosocial belonging - the sense of membership in a group - is an important contributor to one's sense of identity, it is not the only feature that defines someone's identity. In fact, someone's identity is defined by multiple overlapping and competing facets of their lives. In this context, a key element is the consistency that can be found between these competing elements. A mismatch within one's set of beliefs and actions creates cognitive dissonance, which is a feeling of discomfort that emerges when one notices internal disagreements within what one believes and how one acts. Individuals seek to avoid cognitive dissonance and are drawn to novel beliefs and actions that are consistent with their existing beliefs and actions, therefore avoiding anything that forces them to confront internal inconsistencies. An incentive can drive behavioral change by tapping into an individual's desire for consistency with existing beliefs and actions: the feeling that the new behavior being adopted fits seamlessly with one's existing mental model and way of operating in that world.

WB context: In the World Bank setting, diversity and difference among staff members the greatest strengths of the organization. However, from an individual perspective, maintaining consistency with one's own beliefs and actions increases one's sense of self-identity. For example, in a survey delivered to WB staff, $89 \%$ of respondents agreed that sharing knowledge about a project is important to other WB staff because when they have worked on the project from the beginning they want to see it succeed, even if they are moving on to another role. This finding suggests that individuals are incentivized toward certain behaviors in an effort to maintain a commitment with their prior commitments and actions.

\section{Example interventions applied to knowledge sharing:}

Precommitment devices are voluntary tools that allow individuals to solidify their obligation toward a particular action in the future. These tools have proven successful at increasing the likelihood of an individual following through on their promises. 
Precommitment devices have utility in organization settings - an intervention applied to knowledge sharing would involve creating a precommitment mechanism whereby an old TTL commits to a joint mission with the next TTL before they start their new position (see intervention examples in Appendix I).

\section{Driver: Making knowledge sharing easier}

Cognitive load can be used to refer to either the resources that an individual has available to them or the demands that a given cognitive task will require in order to be executed. Biases and heuristics are often described as cognitive strategies (developed through generations of evolution) that allow us to achieve an approximately correct solution while demanding a substantially smaller cognitive load than would be required to reach the exact correct solution. A fully rational agent would gather all the available information, process it exhaustively, and determine the optimal outcome. However, as humans are semi-rational agents that seek to balance the quality of the outcome with the cognitive resources required to reach that outcome, one departs from that idealized rational model in several ways. The tendency to reduce cognitive load (and thus make knowledge sharing easier) is therefore a powerful driver of behavior; because it taps into a core feature of one's cognitive system, this driver can be used to promote change that will be sustained in the long term.

\section{Incentive: Ease of remembering information}

Definition: The first way in which humans seek to reduce cognitive load is by prioritizing information that is easy to retrieve from memory. Information that is hard to remember may not be considered in making a decision or may receive limited consideration relative to information that is retrieved easily. An incentive can drive behavioral change by tapping into an individual's tendency to prioritize information that is easy to remember: the sense that when they need to choose a course of action, the relevant information is at their fingertips.

WB context: Professional work at the WB requires engaging in complex projects involving many individuals. The scale and scope of this work environment creates significant noise in the decision-making environment. In these noisy environments individuals are inclined toward using information that is easiest to recall, as this reduces the total cognitive load. Recalling information is particularly relevant to knowledge sharing because individuals must remember information from past projects and interactions, and pass that information on to their successors. The easier it is to recall information, the greater the incentive to pass it forward.

Example interventions applied to knowledge sharing: As previously noted, the ease of recalling and retrieving information has implications for how likely that information will be used. An intervention that improves the ease of remembering information involves enhancing access to easily shareable and 
highly practical content. By creating a repository of shareable articles that are relevant to one's work context, there is an increased likelihood that the content will be distributed and circulated among World Bank colleagues (see intervention examples in Appendix I).

\section{Incentive: Ease of identifying information}

Definition: The second way in which humans seek to reduce cognitive load is by prioritizing information that is easy to pick out of their surrounding environment. Information that is visually striking, for instance, will be very salient and occupies an important place in one's decision making. By contrast, information that blends in with its background will play a much smaller role in decision making, even if the information itself is very important. An incentive can drive behavioral change by tapping into an individual's tendency to prioritize information that is easily identified: the feeling that individuals need to make a decision and the information that jumps out from their surroundings.

WB context: Because of working in a large institution, WB staff encounter a significant amount of knowledge and information to filter on a daily basis. With many competing demands for their attention and time, it is rational for staff to seek out easily identifiable information that meets their needs. In a survey delivered to WB staff in the context of knowledge sharing, $73 \%$ of respondents agreed that while sharing knowledge is important, prioritizing other tasks is also important, given the limited amount of time and budgets available to dedicate to their own projects. This finding suggests that any effort to encourage specific behaviors will need to account for the effort required of completing the original activity.

Example interventions applied to knowledge sharing: The saliency of information has implications for how easily it is identified. In the context of knowledge sharing, which requires identifying information from various sources, the ease of identifying information can be enhanced through an intervention of sending out automatic 'nudge' e-mails that encourage staff to engage in knowledge-sharing activities. By making relevant information in an individual's immediate environment highly visible, the key message and takeaways become easier to identify (see intervention examples in Appendix I).

\section{Incentive: Ease of processing information}

Definition: The third way in which humans seek to reduce cognitive load is by prioritizing information that is easy to process and work with. If a process is defined for treating different information types, the information type that doesn't fit into any boxes defined by that process is the information least likely to influence the outcome - not because it is the least relevant, but because it is unclear to individuals what they should do with it. 
Between applying a process to the available information and defining a process to handle the available information, the latter is much more work and will often be avoided in order to reduce cognitive load. As a result, information that is difficult to process is likely to be overlooked, no matter its relevance. An incentive can drive behavioral change by tapping into an individual's tendency to prioritize information that it easy to process (and to prefer simpler processes over more complex ones): the sense that there are no open questions about how the information available ought to be considered and weighed.

WB context: With inputs of information coming from many different sources in the World Bank context, there is a significant cognitive load imparted to employees to process a large quantity of information. This is particularly true when employees are working on complex projects with many stakeholders involved. Increasing the salience of the key facts and information relevant to one's work increases the likelihood that this information will be accounted for.

Example interventions applied to knowledge sharing: An intervention that would improve the ease of processing information would involve senior staff highlighting the characteristics of high-quality work. In the context of knowledge sharing, when individuals are faced with a task such as creating a handover package, providing simplified information on how to complete the process successfully reduces the cognitive load associated with the task. Ultimately, this intervention increases the salience of the information necessary for staff members to fulfill their responsibilities (see intervention examples in Appendix I). 


\section{IMPLEMENTATION THEORY FOR IMPACTFUL BEHAVIORAL INTERVENTIONS}

Illustrative Example of the Implementation Theory Applied

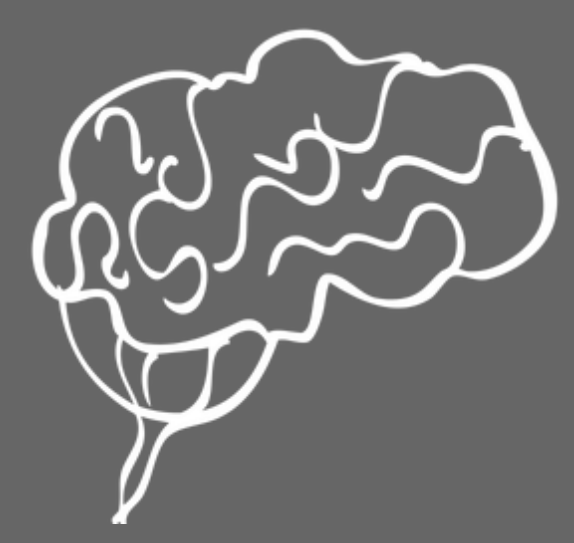




\section{Implementation Theory for Impactful Behavioral Interventions}

\section{Illustrative Example of the Implementation Theory Applied}

Norma, a senior staffer at the Bank, has leveraged the behavioral insights from the incentive framework to determine a pathway for behavioral change and is now ready to implement her behavioral interventions. However, she is evidence-driven and doesn't want to rush into the process without a plan. She wants an approach to test for and measure the impacts of the intervention. She has limited funds and time to test her interventions using a Randomized Control Trial (RCT), so she needs an alternative methodology to evaluate the outcomes on behavioral change. She references the Implementation Theory to develop her evaluation plan. The first step in the evaluation process is revisiting the goal of the intervention itself, which defines the desired behavioral outcome. The second step involves defining the concrete Key Performance Indicators (KPIs). The third step is an iterative assessment to determine if (a) the KPIs are achieved as a result of the intervention, and (b) if there is a long term impact as determined through iterative evaluation. Norma applies this philosophy to the specific context of her interventions.

Norma begins the implementation process with her first intervention. This intervention involves sending out an e-mail to her colleagues, highlighting the valuable insights offered by a report written by a junior team member. First, she revisits the intended behavioral outcome of the intervention-support the self-actualization of her peers by promoting the use of the report specifically and the sharing of knowledge in general. The second step is defining the KPIs for the intervention. She determines the key indicators are (1) the number of report downloads and (2) the number of shares. Finally, she determines that she will assess the impact of the intervention by comparing the number of downloads and shares before and after her intervention.

Following her experiment with the first intervention, Norma feels more confident in her ability to implement interventions. Her second intervention involves socializing the report she promoted in the first intervention. She does so by presenting on the topic of the report at a unit meeting. Before the meeting she identifies her goal: promote the use of the report and reinforce the norms around knowledge-sharing activities by making them more social. Next, she establishes the KPI of the number of participants in the workshop who downloaded the report and put forward ideas for using it in their own work. Her tool for evaluating this KPI is to provide a short survey to unit members before and after the unit meeting. By using two surveys, she can quantify the impact of socializing the report among her unit members on report usage and attitudes toward knowledge sharing more generally. 
After the first two successful interventions, Norma wants to focus on behavioral change relating to knowledge sharing norms at the unit level. Her intervention is intended to make relevant information easy to use by summarizing the key information in the report in key bullet points and using a catchy acronym. Before rolling out her intervention, she reminds herself of the goal-increasing use and understanding of the report while setting an example for her fellow unit members on how information can be presented for ease of processing and identifying information. The KPI she determines for achieving this goal is the increased uptake in use of the report following the e-mail to her colleagues that includes the summary and the link to the entry in the knowledge database. She compares this data to the results from her first intervention to determine if there was a significant effect from her additional behavioral intervention work.

\section{Behavioral Interventions are Necessarily Iterative}

After implementing and evaluating three behavioral interventions, she becomes aware of the importance of testing and iteration. She learns that the first intervention had a much smaller impact on a small number of her peers using the report. She did not observe a noticeable change in the number of downloads of the report before and after her intervention. In her evaluation process she realizes that there was potential for great buy-in around the report if it were socialized within her unit. This leads Norma to the second intervention, which more successfully gained traction. In fact, many of the unit members participated in the unit meeting and offered ideas for how their work was relevant to the report. Norma realized that certain components report resonated with her peers. With this finding, she develops a third intervention that leverages the information most salient to her unit members. She finds that her prior research allowed her to create the most effective intervention. She observed a significant increase in the number of downloads and shares of the report. Ultimately, the iterative process of explicitly defining goals, and determining measurable KPIs and ongoing assessments, allowed Norma to implement successful interventions. 
NEXT STEPS TO MAKE KNOWLEDGE SHARING A REALITY

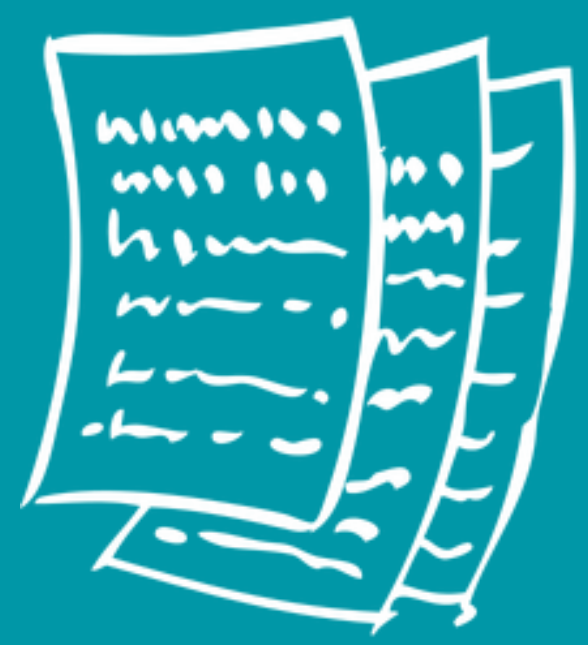




\section{Next Steps to Make Knowledge Sharing a Reality}

Knowledge sharing is due for a redesign. A more human-centered approach to promoting positive knowledge-sharing behaviors is required in order to achieve significant and sustainable change - one based on understanding how people are motivated and grounded in validating frameworks for behavior change. The framework which was presented in this report takes a first step in the direction of creating more evidence-based knowledge-sharing incentives. It is based on a deep dive into WB knowledge-sharing attitudes across $300+$ staff members and provides actionable next steps that tackle the biggest barriers to knowledge sharing. It is the intention that the insights presented in this report, and the framework for applying the insights, can be applied in real-world knowledge-sharing scenarios. While this framework is a great starting point for thinking about how behavioral science tactics can augment knowledge-sharing behaviors, it is meant as a jumpstart and not a complete solution. For this reason, practitioners hoping to apply the Incentive Framework Toolkit should contact jrusinek@worldbank.org in order to discuss possible implementation strategies. 


\section{References}

Ajmal, M., Helo, P., and Kekäle, T. (2010). Critical factors for knowledge management in project business.

Journal of Knowledge Management, 14(1), 156-168. https://doi.org/10.1108/13673271011015633

Avenberg, A., and Sjöblom, A. (n.d.). Gamification in knowledge management: How to score intrinsically in the game of motivation. 98.

Bartol, K. M., and Srivastava, A. (2002). Encouraging Knowledge Sharing: The Role of Organizational Reward Systems. Journal of Leadership \& Organizational Studies, 9(1), 64-76. https://doi.org/10.1177/107179190200900105

Becerra-Fernandez, I., and Sabherwal, R. (2010). Knowledge management: systems and processes. Armonk, N.Y: M.E. Sharpe.

Botha, D. (n.d.). Knowledge Management and the Future of Work. 11.

Dubbeld, W., and Blomme, R. (n.d.). Knowledge Creation in Client-Consultant Interaction: A Case Study. 9.

Fey, C. F., and Furu, P. (2008). Top management incentive compensation and knowledge sharing in multinational corporations. Strategic Management Journal, 29(12), 1301-1323. https://doi.org/10.1002/smj.712

Gold, A. H., Malhotra, A., and Segars, A. H. (2001). Knowledge Management: An Organizational Capabilities Perspective. Journal of Management Information Systems, 18(1), 185-214. https://doi.org/10.1080/07421222.2001.11045669

Huang, L.-S., and Lai, C.-P. (2012). An investigation on critical success factors for knowledge management using structural equation modeling. Procedia-Social and Behavioral Sciences, 40, 24-30. https://doi.org/10.1016/j.sbspro.2012.03.156

Iyer, G. S., and Ravindran, S. (2009). Usefulness, incentives and knowledge management. Journal of Knowledge Management, 13(6), 410-430. https://doi.org/10.1108/13673270910997097

Jahani. (2011). Is Reward System and Leadership Important in Knowledge Sharing Among Academics? American Journal of Economics and Business Administration, 3(1), 87-94. https://doi.org/10.3844/ajebasp.2011.87.94

Jamm, D. (n.d.). Intra-Organizational Knowledge Creation and Sharing in a Principal-Agent Setting. 29. 
Jennex, M. E. (Ed.). (2005). Case studies in knowledge management. Hershey PA: Idea Group Pub.

Khazieva, N., Tomé, E., and Caganova, D. (n.d.). Why Knowledge Management Fails. 13.

Lai, J.-Y. (2009). How reward, computer self-efficacy, and perceived power security affect knowledge management systems success: An empirical investigation in high-tech companies. Journal of the American Society for Information Science and Technology, 60(2), 332-347. https://doi.org/10.1002/asi.20982

Lyu, H., and Zhang, Z. (Justin). (2016). Incentives for knowledge sharing: impact of organisational culture and information technology. Enterprise Information Systems, 1-20. https://doi.org/10.1080/17517575.2016.1273393

Michie, Susan, Maartje M. van Stralen, and Robert West. 2011. "The Behaviour Change Wheel: A New Method for Characterising and Designing Behaviour Change Interventions." Implementation Science 6 (1): 42. https://doi.org/10.1186/1748-5908-6-42.

Nam Nguyen, H., and Mohamed, S. (2011). Leadership behaviors, organizational culture and knowledge management practices: An empirical investigation. Journal of Management

Development, 30(2), 206-221. https://doi.org/10.1108/02621711111105786

Politis, J. D. (2001). The relationship of various leadership styles to knowledge management. Leadership \& Organization Development Journal, 22(8), 354-364. https://doi.org/10.1108/01437730110410071

Šajeva, S. (2014). Encouraging Knowledge Sharing among Employees: How Reward Matters. Procedia-Social and Behavioral Sciences, 156, 130-134. https://doi.org/10.1016/j.sbspro.2014.11.134

Sandel, Michael J. 2013. What Money Can’t Buy: The moral limits of markets. MacMillan.

Semar, D. W. (2004). Incentive systems in knowledge management to support cooperative distributed forms of creating and acquiring knowledge. 6 .

Shin, M. (2004). A framework for evaluating economics of knowledge management systems. Information \& Management, 42(1), 179-196. https://doi.org/10.1016/j.im.2003.06.006 
Singh, M. D., and Kant, R. (2008). Knowledge management barriers: An interpretive structural modeling approach. International Journal of Management Science and Engineering Management, 3(2), 141-150. https://doi.org/10.1080/17509653.2008.10671042

Sung-Ho Yu, Young-Gul Kim, and Min-Yong Kim. (2004). Linking organizational knowledge management drivers to knowledge management performance: an exploratory study. 37th Annual Hawaii International Conference on System Sciences, 2004. Proceedings of The, $10 \mathrm{pp}$. https://doi.org/10.1109/HICSS.2004.1265572

Sutton, M. (2006). Knowledge citizen's approach to knowledge sharing, rewards and incentive. Journal of Information Management, 8(3). https://doi.org/10.4102/sajim.v8i3.224

Venkatraman, S., and Venkatraman, R. (2018). Communities of Practice Approach for Knowledge Management Systems. Systems, 6(4), 36. https://doi.org/10.3390/systems6040036

Wang, S., Noe, R. A., and Wang, Z.-M. (2014). Motivating Knowledge Sharing in Knowledge Management Systems: A Quasi-Field Experiment. Journal of Management, 40(4), 978-1009. https://doi.org/10.1177/0149206311412192

Yang, J. (2010). The knowledge management strategy and its effect on firm performance: A contingency analysis. International Journal of Production Economics, 125(2), 215-223. https://doi.org/10.1016/j.ijpe.2010.03.012

Zhang, L., and Zhang, Z. (2014). The Effects of Incentive Mechanism on Knowledge Management Performance in China: The Moderating Role of Knowledge Attributes. Project Management Journal, 45(2), 34- 47. https://doi.org/10.1002/pmj.21403

Zhang, X., Chen, Z., Vogel, D., Yuan, M., and Guo, C. (2010). Knowledge-sharing reward dynamics in knowledge management systems: Game theory-based empirical validation. Human Factors and Ergonomics in Manufacturing \& Service Industries, 20(2), 103-122. https://doi.org/10.1002/hfm.20203

Zhang, X., Pablos, P. O. de, and Zhou, Z. (2013). Effect of knowledge sharing visibility on incentive-based relationship in Electronic Knowledge Management Systems: An empirical investigation. Computers in Human Behavior, 29(2), 307-313. https://doi.org/10.1016/j.chb.2012.01.029 


\section{Appendix I: Intervention Examples}

\section{TABLE 1: Overview of intervention examples}

\begin{tabular}{|c|c|c|c|c|c|c|c|c|}
\hline \multirow{2}{*}{$\begin{array}{l}\text { Behavioral } \\
\text { Driver }\end{array}$} & \multirow[t]{2}{*}{ Ref. } & \multirow{2}{*}{$\begin{array}{l}\text { Intervention } \\
\text { Name }\end{array}$} & \multirow[t]{2}{*}{ Description } & \multirow[t]{2}{*}{ Incentive } & \multicolumn{3}{|c|}{ Implementation Plan } & \multirow[b]{2}{*}{ KPIs } \\
\hline & & & & & When to use & $\begin{array}{l}\text { Delivery } \\
\text { channels }\end{array}$ & Costs & \\
\hline \multirow[t]{4}{*}{$\begin{array}{l}\text { Making } \\
\text { Knowledge } \\
\text { Sharing } \\
\text { More Social }\end{array}$} & $\mathrm{i}$ & $\begin{array}{l}\text { Introducing } \\
\text { safe spaces }\end{array}$ & $\begin{array}{l}\text { Leverage desire for } \\
\text { inclusion by providing } \\
\text { safe spaces where } \\
\text { staff can discuss } \\
\text { high-impact, but } \\
\text { potentially } \\
\text { stigmatizing topics. }\end{array}$ & $\begin{array}{l}\text { Desire for } \\
\text { inclusion }\end{array}$ & $\begin{array}{l}\text { Whenever team } \\
\text { members } \\
\text { requests via } \\
\text { "time out" or } \\
\text { submits a "safe } \\
\text { space card" }\end{array}$ & $\begin{array}{l}\text { F2F w/online } \\
\text { components for } \\
\text { remote staff } \\
\text { (i.e., webex) }\end{array}$ & $\begin{array}{l}\text { Staff \& } \\
\text { facilitator time }\end{array}$ & $\begin{array}{l}\# \text { of safe space } \\
\text { meetings held }\end{array}$ \\
\hline & ii & $\begin{array}{l}\text { Gaining } \\
\text { precommitme } \\
\text { nts }\end{array}$ & $\begin{array}{l}\text { Leverage desire for } \\
\text { consistency with } \\
\text { beliefs and actions by } \\
\text { using precommitment } \\
\text { mechanisms to boost } \\
\text { joint mission } \\
\text { engagement. }\end{array}$ & $\begin{array}{l}\text { Desire for } \\
\text { consistency } \\
\text { with beliefs and } \\
\text { actions }\end{array}$ & $\begin{array}{l}\text { When } \\
\text { handover } \\
\text { members are } \\
\text { identified, } \\
\text { these can be } \\
\text { automatically } \\
\text { locked in } \\
\text { calendars by } \\
\text { front office } \\
\text { team }\end{array}$ & $\begin{array}{l}\text { Onboarding; } \\
\text { job interview; } \\
\text { letter of } \\
\text { acceptance } \\
\text { (LOA) signing }\end{array}$ & $\begin{array}{l}\text { Cost of joint } \\
\text { mission; LOA } \\
\text { signing }\end{array}$ & $\begin{array}{l}\text { Increased uptake in } \\
\text { staff engaging in } \\
\text { joint missions } \\
\text { Role transition } \\
\text { descriptions and } \\
\text { contracts include a } \\
\text { commitment clause }\end{array}$ \\
\hline & iii & $\begin{array}{l}\text { Enforcing } \\
\text { standardized } \\
\text { handover } \\
\text { guidance }\end{array}$ & $\begin{array}{l}\text { Leverage desire for } \\
\text { immediate feedback } \\
\text { by providing } \\
\text { self-guiding templates } \\
\text { for preparing } \\
\text { handover packages. }\end{array}$ & $\begin{array}{l}\text { Desire for social } \\
\text { support }\end{array}$ & $\begin{array}{l}\text { When team } \\
\text { member is } \\
\text { identified as } \\
\text { rotating out of } \\
\text { a role, prompts } \\
\text { (via multiple } \\
\text { channels) } \\
\text { reminder of } \\
\text { this task (also } \\
\text { applicable for } \\
\text { incoming) }\end{array}$ & $\begin{array}{l}\text { Prompt e-mail; } \\
\text { reminder } \\
\text { e-mails; pop-up } \\
\text { window }\end{array}$ & $\begin{array}{l}\text { Design of } \\
\text { template; } \\
\text { no recurring } \\
\text { cost }\end{array}$ & $\begin{array}{l}\text { \# of handover } \\
\text { packages }\end{array}$ \\
\hline & iv & $\begin{array}{l}\text { Senior staff } \\
\text { mentoring }\end{array}$ & $\begin{array}{l}\text { Leverage desire for } \\
\text { social support and } \\
\text { reduce time pressures } \\
\text { by providing coaching } \\
\text { for handover package } \\
\text { creation. }\end{array}$ & $\begin{array}{l}\text { Desire for social } \\
\text { support }\end{array}$ & $\begin{array}{l}\text { When junior } \\
\text { TTLs are } \\
\text { rotating in or } \\
\text { out of project } \\
\text { lead roles }\end{array}$ & $\begin{array}{l}\text { E-mail; webex; } \\
\text { F2F }\end{array}$ & $\begin{array}{l}1-3 \text { days of staff } \\
\text { time }\end{array}$ & $\begin{array}{l}\text { \# of requests sent } \\
\text { to senior staff } \\
\text { (could be } \\
\text { facilitated by } \\
\text { DECKS) } \\
\text { \# of interactions } \\
\text { between senior \& } \\
\text { junior staff } \\
\text { (monitored by } \\
\text { DECKS or via } \\
\text { webApp) }\end{array}$ \\
\hline
\end{tabular}




\begin{tabular}{|c|c|c|c|c|c|c|c|c|}
\hline & $\mathrm{v}$ & $\begin{array}{l}\text { Introducing } \\
\text { knowledge } \\
\text { sharing } \\
\text { chargeback } \\
\text { codes }\end{array}$ & $\begin{array}{l}\text { Leverage desire to } \\
\text { follow formal norms } \\
\text { for KM activities by } \\
\text { making available a } \\
\text { "KM Chargeback } \\
\text { code" to be used for } \\
\text { all handover activities. }\end{array}$ & $\begin{array}{l}\text { Desire to follow } \\
\text { formal norms }\end{array}$ & $\begin{array}{l}\text { [If charge code } \\
\text { is available] } \\
\text { during } \\
\text { handover } \\
\text { activities, at } \\
\text { unit's } \\
\text { discretion }\end{array}$ & E-mail; intranet & $\begin{array}{l}\text { Cost to establish } \\
\text { mechanism \& } \\
\text { distribution of } \\
\text { messages; KM } \\
\text { activities budget }\end{array}$ & $\begin{array}{l}\text { \# of activities } \\
\text { charged back }\end{array}$ \\
\hline & vi & $\begin{array}{l}\text { Enabling joint } \\
\text { missions }\end{array}$ & $\begin{array}{l}\text { Leverage desire for } \\
\text { participation in } \\
\text { management activities } \\
\text { by enabling managers } \\
\text { to facilitate } \\
\text { collaboration between } \\
\text { incoming and } \\
\text { outgoing staff. }\end{array}$ & $\begin{array}{l}\text { Desire for } \\
\text { participation in } \\
\text { management }\end{array}$ & $\begin{array}{l}\text { At TTL } \\
\text { transition } \\
\text { points }\end{array}$ & Webex; F2F & $\begin{array}{l}\text { Overhead time } \\
\text { spent facilitating } \\
\text { meeting and } \\
\text { spending time } \\
\text { on meeting }\end{array}$ & $\begin{array}{l}\text { \# of management } \\
\text { meetings on this } \\
\text { topic } \\
\text { \# of requests to } \\
\text { meet on this topic }\end{array}$ \\
\hline & vii & $\begin{array}{l}\text { Ensuring } \\
\text { personal } \\
\text { learning } \\
\text { opportunities }\end{array}$ & $\begin{array}{l}\text { Leverage desire for } \\
\text { inclusion and personal } \\
\text { ownership by } \\
\text { encouraging senior } \\
\text { staff to publicly } \\
\text { recognize the value of } \\
\text { non-ToR related } \\
\text { trainings. }\end{array}$ & $\begin{array}{l}\text { Desire for } \\
\text { inclusion }\end{array}$ & $\begin{array}{l}\text { At any } \\
\text { opportunity as } \\
\text { part of } \\
\text { continuous } \\
\text { conversations } \\
\text { related to } \\
\text { and/or separate } \\
\text { from } \\
\text { project-based } \\
\text { interactions. }\end{array}$ & $\begin{array}{l}\text { Departmental } \\
\text { meetings \& } \\
\text { e-mails }\end{array}$ & $\begin{array}{l}\text { Time \& cost of } \\
\text { training }\end{array}$ & $\begin{array}{l}\text { \# of non-TOR } \\
\text { related trainings } \\
\text { taken and } \\
\text { announced } \\
\text { \# of } \\
\text { statements/testimo } \\
\text { nies about } \\
\text { quality/content of } \\
\text { non-TOR trainings } \\
\text { taken (i.e., brief } \\
\text { videos) }\end{array}$ \\
\hline \multirow[t]{2}{*}{$\begin{array}{l}\text { Making } \\
\text { Knowledge } \\
\text { Sharing } \\
\text { Easier }\end{array}$} & viii & $\begin{array}{l}\text { Management } \\
\text { recognizing } \\
\text { outstanding } \\
\text { handover } \\
\text { packages }\end{array}$ & $\begin{array}{l}\text { Leverage } \\
\text { psychological salience } \\
\text { of knowledge sharing } \\
\text { activities by } \\
\text { prompting senior staff } \\
\text { to highlight } \\
\text { high-quality handover } \\
\text { packages. }\end{array}$ & $\begin{array}{l}\text { Ease of } \\
\text { processing } \\
\text { information }\end{array}$ & $\begin{array}{l}\text { Examples } \\
\text { shared within } 1 \\
\text { month of a } \\
\text { staff member's } \\
\text { role transition } \\
\text { by e-mail } \\
\text { and/or during } \\
\text { training for } \\
\text { new roles, } \\
\text { reminder } \\
\text { e-mail } 1 \text { week } \\
\text { before the staff } \\
\text { transition } \\
\text { occurs }\end{array}$ & $\begin{array}{l}\text { Unit e-mails, } \\
\text { town hall } \\
\text { meetings, } \\
\text { newsletters } \\
\text { sent by senior } \\
\text { staff *all } \\
\text { output should } \\
\text { be addressed } \\
\text { by senior staff } \\
\text { members* }\end{array}$ & $\begin{array}{l}\text { Time spent to } \\
\text { create } \\
\text { exemplary } \\
\text { handover } \\
\text { packages and to } \\
\text { send and share } \\
\text { examples }\end{array}$ & $\begin{array}{l}\text { \# of senior staff } \\
\text { disseminating } \\
\text { e-mails, sharing } \\
\text { resources at town } \\
\text { halls, etc. } \\
\text { \# of salient } \\
\text { examples of good } \\
\text { handover packages } \\
\text { sent }\end{array}$ \\
\hline & ix & $\begin{array}{l}\text { Introducing } \\
\text { individualized } \\
\text { knowledge- } \\
\text { sharing } \\
\text { scorecards }\end{array}$ & $\begin{array}{l}\text { Leverage } \\
\text { psychological salience } \\
\text { by making knowledge } \\
\text { sharing and } \\
\text { consumption visible } \\
\text { via updated e-mails. }\end{array}$ & $\begin{array}{l}\text { Ease of } \\
\text { processing } \\
\text { information }\end{array}$ & $\begin{array}{l}\text { Summary } \\
\text { e-mail with } \\
\text { statistics sent } \\
\text { monthly (tbd) }\end{array}$ & E-mail & $\begin{array}{l}\text { Design of } \\
\text { analytical } \\
\text { platform; } \\
\text { maintenance; } \\
\text { time of staff to } \\
\text { post/search }\end{array}$ & $\begin{array}{l}\text { \# of citations to } \\
\text { particular staff } \\
\text { \# of automated } \\
\text { e-mails sent }\end{array}$ \\
\hline
\end{tabular}




\begin{tabular}{|c|c|c|c|c|c|c|c|c|}
\hline & $\mathrm{x}$ & $\begin{array}{l}\text { Triggering } \\
\text { automated } \\
\text { reminders }\end{array}$ & $\begin{array}{l}\text { Leverage contextual } \\
\text { salience by sending } \\
\text { out automatic e-mails } \\
\text { that nudge staff to } \\
\text { engage in } \\
\text { knowledge-sharing } \\
\text { behaviors. }\end{array}$ & $\begin{array}{l}\text { Ease of } \\
\text { identifying } \\
\text { information }\end{array}$ & $\begin{array}{l}\text { Nudge e-mails } \\
\text { sent at strategic } \\
\text { times (e.g., } \\
\text { during role } \\
\text { transitions, at } \\
\text { concept note } \\
\text { stage, etc., this } \\
\text { can be } \\
\text { automated) }\end{array}$ & $\begin{array}{l}\text { E-mail/pop-up/ } \\
\text { SMS }\end{array}$ & $\begin{array}{l}\text { Design and } \\
\text { maintenance of } \\
\text { system, machine } \\
\text { learning/AI }\end{array}$ & $\begin{array}{l}\text { \# of automated } \\
\text { e-mails/SMS sent } \\
\text { \# of specific } \\
\text { knowledge-sharing } \\
\text { behaviors nudged } \\
\text { staff engages in }\end{array}$ \\
\hline & $\mathrm{xi}$ & $\begin{array}{l}\text { Introducing } \\
\text { learning } \\
\text { stories }\end{array}$ & $\begin{array}{l}\text { Leverage cognitive } \\
\text { ease of retrieval by } \\
\text { enhancing shareable } \\
\text { and highly practical } \\
\text { content. }\end{array}$ & $\begin{array}{l}\text { Ease of } \\
\text { remembering } \\
\text { information }\end{array}$ & $\begin{array}{l}\text { Examples } \\
\text { shared within } 1 \\
\text { month of a } \\
\text { staff member's } \\
\text { role transition } \\
\text { by e-mail } \\
\text { and/or during } \\
\text { training for } \\
\text { new roles, } \\
\text { reminder } \\
\text { e-mail } 1 \text { week } \\
\text { before the staff } \\
\text { transition } \\
\text { occurs }\end{array}$ & E-mail; intranet & $\begin{array}{l}\text { Time spent to } \\
\text { build repository } \\
\text { platform }\end{array}$ & $\begin{array}{l}\text { \# of SPR pieces } \\
\text { posted } \\
\text { \# of SPR pieces } \\
\text { read/downloaded }\end{array}$ \\
\hline $\begin{array}{l}\text { Linking } \\
\text { Knowledge } \\
\text { Sharing to } \\
\text { Self-Develop } \\
\text { ment }\end{array}$ & xii & $\begin{array}{l}\text { Establishing } \\
\text { knowledge } \\
\text {-sharing trust } \\
\text { fund } \\
\text { applications }\end{array}$ & $\begin{array}{l}\text { Leverage desire for } \\
\text { visibility and } \\
\text { knowledge-sharing } \\
\text { norms by establishing } \\
\text { a Knowledge Sharing } \\
\text { Trust Fund. }\end{array}$ & $\begin{array}{l}\text { Desire for } \\
\text { personal } \\
\text { recognition/ } \\
\text { visibility }\end{array}$ & $\begin{array}{l}\text { Project design; } \\
\text { project } \\
\text { evaluation; } \\
\text { new research } \\
\text { products } \\
\text { published by } \\
\text { DECK }\end{array}$ & $\begin{array}{l}\text { Regional } \\
\text { workshops, } \\
\text { eModules, } \\
\text { newsletters, } \\
\text { website, joint } \\
\text { research } \\
\text { missions-any } \\
\text { module that } \\
\text { fosters } \\
\text { knowledge } \\
\text { sharing }\end{array}$ & $\begin{array}{l}\text { 10-100 k USD p } \\
\text { engagement }\end{array}$ & 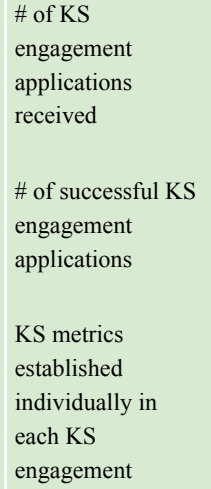 \\
\hline
\end{tabular}




\begin{tabular}{|c|c|c|c|c|c|c|c|}
\hline xiii & $\begin{array}{l}\text { Supporting } \\
\text { social praise }\end{array}$ & $\begin{array}{l}\text { Leverage desire for } \\
\text { confidence by } \\
\text { enabling senior staff } \\
\text { to publicly praise staff } \\
\text { that engaged in a } \\
\text { knowledge-sharing } \\
\text { behavior. }\end{array}$ & $\begin{array}{l}\text { Desire for } \\
\text { confidence }\end{array}$ & $\begin{array}{l}\text { Each time } \\
\text { when staff } \\
\text { engages in } \\
\text { specific } \\
\text { knowledge-sha } \\
\text { ring behavior }\end{array}$ & $\begin{array}{l}\text { Departmental } \\
\text { meetings \& } \\
\text { e-mails \& } \\
\text { internal people } \\
\text { profiles }\end{array}$ & $\begin{array}{l}\text { Time to design } \\
\& \text { implement } \\
\text { mechanism }\end{array}$ & $\begin{array}{l}\text { \# of senior staff } \\
\text { engaging in social } \\
\text { recognition } \\
\text { activities } \\
\text { \# of staff } \\
\text { recognized by } \\
\text { senior staff for } \\
\text { engaging in } \\
\text { knowledge-sharing } \\
\text { behaviors }\end{array}$ \\
\hline xiv & $\begin{array}{l}\text { Salary } \\
\text { Revenue } \\
\text { Increase } \\
\text { (SRI) score } \\
\text { enhancement }\end{array}$ & $\begin{array}{l}\text { Leverage desire for } \\
\text { status by formally } \\
\text { rewarding staff } \\
\text { through SRI } \\
\text { categories for } \\
\text { engaging in } \\
\text { knowledge-sharing } \\
\text { behaviors. }\end{array}$ & Desire for status & $\begin{array}{l}\text { When staff } \\
\text { joins new unit } \\
\text { and } \\
\text { performance } \\
\text { objectives are } \\
\text { set; during } \\
\text { mid-term } \\
\text { review } \\
\text { meetings; } \\
\text { during official } \\
\text { performance } \\
\text { review } \\
\text { meetings }\end{array}$ & $\begin{array}{l}\text { Line } \\
\text { management \& } \\
\text { HRBP (through } \\
\text { onboarding \& } \\
\text { performance } \\
\text { evaluation } \\
\text { conversations) }\end{array}$ & $\begin{array}{l}\text { Time spent to } \\
\text { re-adjust formal } \\
\text { performance } \\
\text { evaluations } \\
\text { standards; time } \\
\text { needed to coach } \\
\text { management } \\
\text { and HR on this } \\
\text { new evaluation } \\
\text { criteria; } \\
\text { monetary cost of } \\
\text { potential } \\
\text { rewards; time } \\
\text { spent to engage } \\
\text { in specific } \\
\text { knowledge-shari } \\
\text { ng behavior }\end{array}$ & $\begin{array}{l}\text { \# of SRIs } \\
\text { successfully } \\
\text { marked with bonus } \\
\text { points } \\
\text { \# of top } 10 \text { lists } \\
\text { circulated within } \\
\text { institution } \\
\\
\text { \# of capacity } \\
\text { building sessions } \\
\text { provided on top } 10 \\
\text { lists (or other } \\
\text { specific } \\
\text { knowledge-sharing } \\
\text { behaviors) }\end{array}$ \\
\hline $\mathrm{xV}$ & $\begin{array}{l}\text { Senior } \\
\text { management } \\
\text { role modeling }\end{array}$ & $\begin{array}{l}\text { Leverage desire for } \\
\text { status by enabling } \\
\text { senior staff to call } \\
\text { attention to staff } \\
\text { engagement with } \\
\text { knowledge-sharing } \\
\text { behaviors. }\end{array}$ & Desire for status & Periodically & $\begin{array}{l}\text { Town halls; } \\
\text { departmental } \\
\text { meetings; team } \\
\text { retreats }\end{array}$ & $\begin{array}{l}\text { Time for sen } \\
\text { mgmt briefing }\end{array}$ & $\begin{array}{l}\text { \# of senior staff } \\
\text { championing the } \\
\text { behavior }\end{array}$ \\
\hline
\end{tabular}




\begin{tabular}{|c|c|c|c|c|c|c|c|}
\hline xvi & $\begin{array}{l}\text { Introducing } \\
\text { Knowledge } \\
\text { Sharer Badge } \\
\text { points }\end{array}$ & $\begin{array}{l}\text { Leverage desire for } \\
\text { status and recognition } \\
\text { for engaging in KM } \\
\text { activities by } \\
\text { displaying } \\
\text { "Knowledge Sharer } \\
\text { Badges" on user } \\
\text { profiles. }\end{array}$ & Desire for status & $\begin{array}{l}\text { Each time a } \\
\text { staff member } \\
\text { recognizes } \\
\text { another as } \\
\text { having } \\
\text { completed a } \\
\text { valuable } \\
\text { knowledge } \\
\text {-sharing } \\
\text { activity }\end{array}$ & $\begin{array}{l}\text { Integrated on } \\
\text { user profiles } \\
\text { (Peoples Page); } \\
\text { in e-mail } \\
\text { signatures; }\end{array}$ & None & $\begin{array}{l}\text { \# of KSBs linked } \\
\text { to profile } \\
\text { \# of KSBs awarded } \\
\text { to others }\end{array}$ \\
\hline xvii & $\begin{array}{l}\text { Establishing } \\
\text { activity } \\
\text { reminders }\end{array}$ & $\begin{array}{l}\text { Leverage individual } \\
\text { desire for status by } \\
\text { providing peer } \\
\text { recognition and } \\
\text { encouragement via } \\
\text { e-mails. }\end{array}$ & $\begin{array}{l}\text { Desire for } \\
\text { personal } \\
\text { recognition/visi } \\
\text { bility }\end{array}$ & $\begin{array}{l}\text { Each time after } \\
\text { someone has } \\
\text { shared a good } \\
\text { piece }\end{array}$ & $\begin{array}{l}\text { E-mail; CISCO } \\
\text { Jabber/ } \\
\text { Yammer } \\
\text { messages }\end{array}$ & $\begin{array}{l}\text { Minimal; } \\
\text { recognition } \\
\text { templates } \\
\text { designed by } \\
\text { DECKS and } \\
\text { distributed to } \\
\text { senior } \\
\text { management } \\
\text { assistants (ACS) }\end{array}$ & $\begin{array}{l}\text { \# of public } \\
\text { recognitions } \\
\text { received (staff); \# } \\
\text { of public } \\
\text { recognitions sent } \\
\text { (management); \# of } \\
\text { public recognitions } \\
\text { published (unit) }\end{array}$ \\
\hline xviii & $\begin{array}{l}\text { Standardizing } \\
\text { overall } \\
\text { performance } \\
\text { evaluation } \\
\text { (OPE) } \\
\text { indicators }\end{array}$ & $\begin{array}{l}\text { Leverage individual } \\
\text { desire for status by } \\
\text { formally recognizing } \\
\text { joint mission } \\
\text { participation within } \\
\text { OPEs. }\end{array}$ & Desire for status & $\begin{array}{l}\text { Linked to OPE } \\
\text { cycle }\end{array}$ & $\begin{array}{l}\text { OPE } \\
\text { conversation }\end{array}$ & $\begin{array}{l}\text { Cost for change } \\
\text { of OPE design } \\
\& \text { capacity } \\
\text { building efforts }\end{array}$ & $\begin{array}{l}\text { \# of OPEs } \\
\text { including "joint } \\
\text { mission" } \\
\text { checkmark } \\
\text { checked }\end{array}$ \\
\hline xix & $\begin{array}{l}\text { Publicly } \\
\text { ranking } \\
\text { knowledge-sh } \\
\text { aring } \\
\text { performances }\end{array}$ & $\begin{array}{l}\text { Leverage desire for } \\
\text { individual-group } \\
\text { value alignment by } \\
\text { publicly ranking and } \\
\text { acknowledging the } \\
\text { units whose members } \\
\text { engage in } \\
\text { knowledge-sharing } \\
\text { behaviors. }\end{array}$ & $\begin{array}{l}\text { Desire for } \\
\text { individual-grou } \\
\mathrm{p} \text { value } \\
\text { alignment }\end{array}$ & $\begin{array}{l}\text { Monthly or } \\
\text { quarterly (tbd) }\end{array}$ & $\begin{array}{l}\text { E-mail; } \\
\text { intranet; } \\
\text { automatized } \\
\text { algorithm }\end{array}$ & $\begin{array}{l}\text { Cost to establish } \\
\text { mechanism } \\
\text { (algorithm for } \\
\text { rankings) \& } \\
\text { distribution of } \\
\text { messages }\end{array}$ & $\begin{array}{l}\text { \# of rankings } \\
\text { published }\end{array}$ \\
\hline $\mathrm{xx}$ & $\begin{array}{l}\text { Management } \\
\text { endorsing } \\
\text { peer } \\
\text { recognition }\end{array}$ & $\begin{array}{l}\text { Leverage desire for } \\
\text { individual } \\
\text { accomplishment by } \\
\text { prompting staff to } \\
\text { send short, relevant, } \\
\text { punchy pieces to } \\
\text { senior directors in } \\
\text { exchange for } \\
\text { recognition and } \\
\text { visibility. }\end{array}$ & $\begin{array}{l}\text { Desire for } \\
\text { individual-grou } \\
\text { p value } \\
\text { alignment }\end{array}$ & Ongoing & $\begin{array}{l}\text { E-mail w } \\
\text { attachment/ } \\
\text { link }\end{array}$ & $\begin{array}{l}\text { Minimal; staff } \\
\text { time }\end{array}$ & $\begin{array}{l}\text { \# of SRP pieces } \\
\text { shared by GD } \\
\text { \# of SRP pieces } \\
\text { submitted to GD } \\
\text { by staff }\end{array}$ \\
\hline
\end{tabular}


TABLE 2: Complete description of knowledge-sharing interventions

\begin{tabular}{|c|c|c|}
\hline $\begin{array}{l}\text { Matrix } \\
\text { Ref. }\end{array}$ & Intervention Name & Description \\
\hline \multicolumn{3}{|c|}{ Making knowledge sharing more social } \\
\hline i & $\begin{array}{l}\text { Introducing safe } \\
\text { spaces-Providing safe spaces } \\
\text { where staff can discuss } \\
\text { high-impact, but potentially } \\
\text { stigmatizing topics. }\end{array}$ & $\begin{array}{l}\text { One of the barriers identified is the lack of strong KS norms, which reduces the social } \\
\text { space for engaging in those activities. Individuals are naturally more confident when they } \\
\text { are in an environment where they can safely share ideas and opinions. A critical aspect of } \\
\text { these safe spaces is that they are overtly nonjudgmental, allowing Bank employees to } \\
\text { openly discuss the gaps or limitations in their knowledge. Safe spaces allow for } \\
\text { knowledge gaps to be explored and knowledge exchanged without threatening } \\
\text { confidence, while creating new social norms. }\end{array}$ \\
\hline ii & $\begin{array}{l}\text { Gaining precommitments-Using } \\
\text { precommitment strategies to boost } \\
\text { joint mission engagement. }\end{array}$ & $\begin{array}{l}\text { When individuals commit to a specific action at a particular time, this tends to motivate } \\
\text { behavior while also reducing procrastination. Commitment also leads to personal } \\
\text { ownership and addresses the barrier of the endowment effect whereby individuals feel } \\
\text { insufficient ownership over their work. Joint missions occur during a transition period } \\
\text { between the old and new staff members. To increase engagement, the outgoing TTL can } \\
\text { pre commit to a joint mission with the incoming TTL at an agreed point in time, in } \\
\text { conjunction with the PM. }\end{array}$ \\
\hline iii & $\begin{array}{l}\text { Enforcing standardized handover } \\
\text { guidance-Leverage the desire for } \\
\text { immediate feedback by providing } \\
\text { self-guiding templates for } \\
\text { preparing handover packages. }\end{array}$ & $\begin{array}{l}\text { Staff members consistently seek out feedback on their work as a source of information } \\
\text { and validation. The desire for immediate feedback can be leveraged by providing staff } \\
\text { with self-guiding templates for preparing handover packages at their own timing and } \\
\text { discretion. This intervention would be applied each time a staff member is preparing to } \\
\text { rotate out of a role. Feedback on the quality of this task simplifies and improves the } \\
\text { process - as well as the experience of the supervisor and incoming staff member (as a } \\
\text { reduced cognitive load). }\end{array}$ \\
\hline iv & $\begin{array}{l}\text { Senior staff mentoring-Leverage } \\
\text { desire for social support by } \\
\text { providing senior coaching during } \\
\text { handover transition. }\end{array}$ & $\begin{array}{l}\text { Personal coaching can motivate and guide staff to improve the quality and delivery of } \\
\text { their work. Additionally, it can address the barrier of insufficient training for KS } \\
\text { activities. An intervention for contextualizing core elements during a handover (often } \\
\text { those insights are not captured or capturable) and improving staff capacity could involve } \\
\text { the provision of coaching services by more senior bank members to less experienced } \\
\text { members, particularly those needing to hand over to others. This intervention would } \\
\text { facilitate handover knowledge transfer while allowing more junior staff to connect to } \\
\text { senior staff for safe guidance. }\end{array}$ \\
\hline $\mathbf{v}$ & $\begin{array}{l}\text { Introducing knowledge-sharing } \\
\text { chargeback codes-By formalizing } \\
\text { KS activities }\end{array}$ & $\begin{array}{l}\text { Tasks that do not make up a staff member's everyday responsibilities (as defined by } \\
\text { project work) are likely to become lower priority, especially if there is no charge code. } \\
\text { Providing a specific charge code for key knowledge-sharing activities, e.g., such as } \\
\text { properly preparing a handover package, can ensure this is done in a timely manner. In } \\
\text { turn, this intervention addresses the barrier of insufficient time by creating an explicit } \\
\text { time commitment for the activity. }\end{array}$ \\
\hline vi & $\begin{array}{l}\text { Enabling joint missions-By } \\
\text { facilitating collaboration between } \\
\text { managers }\end{array}$ & $\begin{array}{l}\text { Participating in management activities creates a sense of pride, which is a strong } \\
\text { motivator for behavior. Additionally, it can address the barrier of the endowment effect } \\
\text { which occurs when a staff member lacks a sense of ownership over the outcomes of their } \\
\text { work. This intervention allows former and new managers to connect and discuss how } \\
\text { they can create an enabling environment for outgoing staff to undertake joint missions } \\
\text { with incoming staff. Facilitating this connection allows knowledge exchange to be a } \\
\text { collaborative process between new and old staff. }\end{array}$ \\
\hline
\end{tabular}




\begin{tabular}{|c|c|c|}
\hline vii & $\begin{array}{l}\text { Ensuring personal learning } \\
\text { opportunities_Facilitating } \\
\text { personal learning opportunities } \\
\text { with senior staff influence }\end{array}$ & $\begin{array}{l}\text { For individuals to realize work and personal ambitions, they may require insights and } \\
\text { guidance from senior staff. Such senior staff members encourage junior staff to deepen } \\
\text { their knowledge and strengthen their skills by publicly recognizing the value of } \\
\text { non-ToR-related trainings via e-mails, meetings, or other channels. This public } \\
\text { recognition by senior staff helps address the barrier of insufficient social norms around } \\
\text { KS for junior staff by creating new ones. }\end{array}$ \\
\hline \multicolumn{3}{|c|}{ Making knowledge sharing easier } \\
\hline viii & $\begin{array}{l}\text { Management recognizing } \\
\text { outstanding handover } \\
\text { packages-Senior staff highlight } \\
\text { high-quality work to prompt } \\
\text { knowledge sharing }\end{array}$ & $\begin{array}{l}\text { One of the key barriers to KS is that information is not salient. This is a challenge } \\
\text { because individuals are more compelled to retrieve information or seek out new } \\
\text { information when it is readily available. This availability reduces the overall cognitive } \\
\text { load. The innate desire to reduce cognitive load can be a powerful driver of behavior. An } \\
\text { intervention to make information accessible involves senior staff highlighting the key } \\
\text { characteristics of high-quality knowledge-sharing activities in catchy and salient ways, } \\
\text { such as by using colors, bullet points, and memorable acronyms - a simple but } \\
\text { meaningful demonstration of 'better practice'. }\end{array}$ \\
\hline ix & $\begin{array}{l}\text { Introducing individualized } \\
\text { knowledge-sharing } \\
\text { scorecards-Making knowledge } \\
\text { sharing and consumption visible } \\
\text { via updated e-mails }\end{array}$ & $\begin{array}{l}\text { Receiving feedback on the value of one's contributions can positively reinforce the } \\
\text { efforts that led to that recognition. Simple acts such as individualized e-mails updating } \\
\text { staff on the number of times their reports or notes have been downloaded/searched for in } \\
\text { a database (if such activities are trackable) can be a salient indicator on how one's } \\
\text { knowledge-sharing initiatives (i.e., sharing content) is tangibly valued by peers. }\end{array}$ \\
\hline $\mathbf{x}$ & $\begin{array}{l}\text { Triggering automated } \\
\text { reminders-To nudge staff to } \\
\text { engage in knowledge-sharing } \\
\text { behaviors }\end{array}$ & $\begin{array}{l}\text { One of the key barriers to KM in the Bank is that the information needed for KS is } \\
\text { insufficiently salient to staff. In the context of knowledge sharing, which requires } \\
\text { identifying information from various sources, the ease of identifying information can be } \\
\text { enhanced through an intervention of sending out automatic 'nudge' e-mails that } \\
\text { encourage staff to engage in knowledge-sharing activities. By making relevant } \\
\text { information in an individual's immediate environment highly visible, the key message } \\
\text { and takeaways become easier to identify. }\end{array}$ \\
\hline $\mathbf{x i}$ & $\begin{array}{l}\text { Introducing learning } \\
\text { stories-Enabling easy } \\
\text { identification of highly practical } \\
\text { content to facilitate KS. }\end{array}$ & $\begin{array}{l}\text { In addition to the cognitive load associated with identifying relevant and meaningful } \\
\text { information is the associated task of retrieving information. The easier it is for one to } \\
\text { recall and retrieve information, the more likely it is to be used. An intervention to } \\
\text { improve the ease of recall and retrieval is enhancing a channel to communicate "short } \\
\text { relevant and punchy" development topics across the team or unit. An automated version } \\
\text { could send out specific resources to targeted staff on a regular basis. }\end{array}$ \\
\hline \multicolumn{3}{|c|}{ Linking knowledge sharing to self-development } \\
\hline xii & $\begin{array}{l}\text { Establishing Knowledge-Sharing } \\
\text { Trust Fund applications-To } \\
\text { leverage desire for visibility and } \\
\text { KS norms }\end{array}$ & $\begin{array}{l}\text { Individuals are drawn to activities seen favorably by their peers, although an identified } \\
\text { barrier to KS is the lack of social norms. Visibility toward KS behaviors can be enhanced } \\
\text { through a 'Knowledge-Sharing Trust'. Researchers can co-apply with operations } \\
\text { counterparts (TTL) to a designated fund for engagements that clearly and visibly foster } \\
\text { knowledge sharing across the WB (and beyond with external partner involvement), } \\
\text { whereby successful applicants to the fund would receive knowledge-sharing coaching } \\
\text { which would focus on making their products applicable to the Bank. }\end{array}$ \\
\hline
\end{tabular}




\begin{tabular}{|c|c|c|}
\hline xiii & $\begin{array}{l}\text { Supporting social praise-To } \\
\text { leverage desire for confidence by } \\
\text { encouraging senior staff to publicly } \\
\text { praise those engaged in KS } \\
\text { behaviors }\end{array}$ & $\begin{array}{l}\text { Managers and senior staff play a key role in fostering an inclusive environment. } \\
\text { Knowledge-sharing behaviors are encouraged in environments where individuals feel } \\
\text { such behaviors are standard practice, especially among the leaders of the group. When } \\
\text { senior staff publicly praise knowledge-sharing activities, they draw attention to specific } \\
\text { actions and demonstrate that KS activities exercised by a staff member warrant the } \\
\text { attention of the entire organization and everyone in it, regardless of their role or seniority. }\end{array}$ \\
\hline xiv & $\begin{array}{l}\text { SRI score enhancement-To } \\
\text { leverage desire for status by } \\
\text { formally rewarding } \\
\text { KS behaviors }\end{array}$ & $\begin{array}{l}\text { While intrinsic motivations play a key role in motivating KS behaviors, extrinsic } \\
\text { motivations can reinforce the intrinsic ones. This was illustrated by a key barrier to } \\
\text { KS-insufficient performance evaluation for KS. The Bank's pre established SRI } \\
\text { categories can serve as a foundation for promoting extrinsic motivations such as status. } \\
\text { An intervention leveraging the status could involve formally rewarding staff through SRI } \\
\text { categories for engaging in knowledge-sharing behaviors. SRI score enhancement signals } \\
\text { to staff that their KS behavior is valued in a material way. }\end{array}$ \\
\hline $\mathrm{xV}$ & $\begin{array}{l}\text { Senior management role } \\
\text { modeling-To leverage desire for } \\
\text { status by enabling senior staff to } \\
\text { call attention to staff engagement } \\
\text { with KS behaviors }\end{array}$ & $\begin{array}{l}\text { One key barrier to KS is a perceived lack of prioritization by senior staff. To address this, } \\
\text { this intervention involves very senior individuals (e.g., VPs or Global/Regional } \\
\text { Directors) discussing specific knowledge-sharing behaviors at retreats or town halls, } \\
\text { conveying that these behaviors are an expectation. Additionally, such senior individual } \\
\text { can use their platforms to draw attention to new templates, pointers, and materials that } \\
\text { will make it easy for their staff to exercise the KS behaviors. }\end{array}$ \\
\hline xvi & $\begin{array}{l}\text { Introducing Knowledge Sharer } \\
\text { Badge points-Leverage desire for } \\
\text { status and recognition for engaging } \\
\text { in KM activities by displaying } \\
\text { "Knowledge Sharing Badges" on } \\
\text { user profiles }\end{array}$ & $\begin{array}{l}\text { Small displays of recognition for one's efforts in the workplace go a long way in } \\
\text { reinforcing future behaviors. Therefore, providing public recognition for } \\
\text { knowledge-sharing activities confers a sense of status to individuals. This } \\
\text { implementation involves a "Knowledge Sharer Badge" displayed on the user profiles of } \\
\text { staff once they engage in a set number/specific Knowledge Sharing activities. Activities } \\
\text { can be peer-based, for example, being acknowledged by another staff member or } \\
\text { system-recognized when an activity takes place online. }\end{array}$ \\
\hline xvii & $\begin{array}{l}\text { Establishing activity } \\
\text { reminders-Leverage individual } \\
\text { desire for status by providing peer } \\
\text { recognition and encouragement via } \\
\text { e-mails. }\end{array}$ & $\begin{array}{l}\text { As previously discussed, insufficient social norms around KS are a key barrier. } \\
\text { Recognition and visibility for positive behaviors is not only important for behavioral } \\
\text { change at the peer-to-peer level, but this recognition should also be displayed at the unit } \\
\text { or departmental level. This intervention involves departmental management sending } \\
\text { friendly encouragements across units/departments recognizing staff devoting time to } \\
\text { creating, finding, and sharing "relevant short punchy pieces." These e-mails of } \\
\text { encouragement can be sent out each time a staff member shares a relevant short punchy } \\
\text { piece. }\end{array}$ \\
\hline xviii & $\begin{array}{l}\text { Standardizing performance } \\
\text { evaluation indicators (OPE)_-To } \\
\text { leverage individual desire for } \\
\text { status by formally recognizing joint } \\
\text { mission participation within OPE. }\end{array}$ & $\begin{array}{l}\text { Formal norms in the workplace aim to ostensibly introduce orderly and predictable ways } \\
\text { of working (behavior). These norms ensure continuity in the organization over time } \\
\text { despite the reality of changes in people. One such norm, Overall Performance } \\
\text { Evaluations (OPEs) play a key role in communicating the types of behaviors that indicate } \\
\text { strong performance. By including a category in OPEs around whether, for example, } \\
\text { TTLs participated in planned joint missions as part of project handovers would signal the } \\
\text { importance of such activities. }\end{array}$ \\
\hline
\end{tabular}




\begin{tabular}{|c|c|c|}
\hline $\mathbf{x x}$ & $\begin{array}{l}\text { Management endorsing peer } \\
\text { recognition-Leverage desire for } \\
\text { individual accomplishment by } \\
\text { prompting staff to send SRP pieces } \\
\text { to senior directors in exchange for } \\
\text { recognition and visibility. }\end{array}$ & $\begin{array}{l}\text { In organizations with a wide range of experience and grades, senior staff members' } \\
\text { acknowledgement of junior staff for knowledge contributions can foster a powerful sense } \\
\text { of accomplishment. An intervention involves prompting staff members to send SRP } \\
\text { pieces directly to their supervisor (PM and above), pointing out the work that was done, } \\
\text { the qualities that made this work noteworthy, and the outcomes that it helped to achieve } \\
\text { (i.e., the impact), along with the name of the staff member who accomplished this task. If } \\
\text { done in an organized manner (e.g., via a monthly submission window), this can be further } \\
\text { enhanced with a competitive component. }\end{array}$ \\
\hline \multicolumn{3}{|c|}{ Beyond the interventions: other potential applications of the framework } \\
\hline $\begin{array}{l}\text { Prov } \\
\text { Ban }\end{array}$ & $\begin{array}{l}\text { ig evidence for the value of World } \\
\text { itiatives using the framework }\end{array}$ & $\begin{array}{l}\text { The framework provides a theoretical foundation for warranting pilot projects and } \\
\text { programs. One such example is the "learning coin"-an existing program in the WB } \\
\text { (initiated by the Independent Evaluation Group) involving a rewards system and teaching } \\
\text { tool to improve idea exchanges on a range of topics including knowledge sharing. The } \\
\text { incentive framework offers a strong foundation to introduce the learning coin and gain } \\
\text { traction with this initiative in the Bank context. Additionally, drawing from behavioral } \\
\text { economic principles of scarcity, the learning coin 'bank' contains a limited number of } \\
\text { coins. This scarcity creates a higher value for each learning coin. Therefore, when staff } \\
\text { members receive a learning coin, it confers a greater sense of achievement. Previous } \\
\text { research on KS in the Bank has illustrated that intrinsic rewards are stronger when tied to } \\
\text { extrinsic rewards - this intervention integrates these two motivators. }\end{array}$ \\
\hline $\begin{array}{l}\operatorname{Imp} \\
\text { doct }\end{array}$ & $\begin{array}{l}\text { ing punctuality and quality of } \\
\text { nt filing }\end{array}$ & $\begin{array}{l}\text { Staff have expressed interest in conducting behavioral diagnostics to address a variety of } \\
\text { operational challenges. An intervention example could involve "nudging' IFC operations } \\
\text { staff to fill out their required documents in a timely fashion. A potential entry point } \\
\text { would involve sending out automated nudges to staff reminding them of their submission } \\
\text { deadlines with a highlighted example of how their work should be completed. }\end{array}$ \\
\hline
\end{tabular}




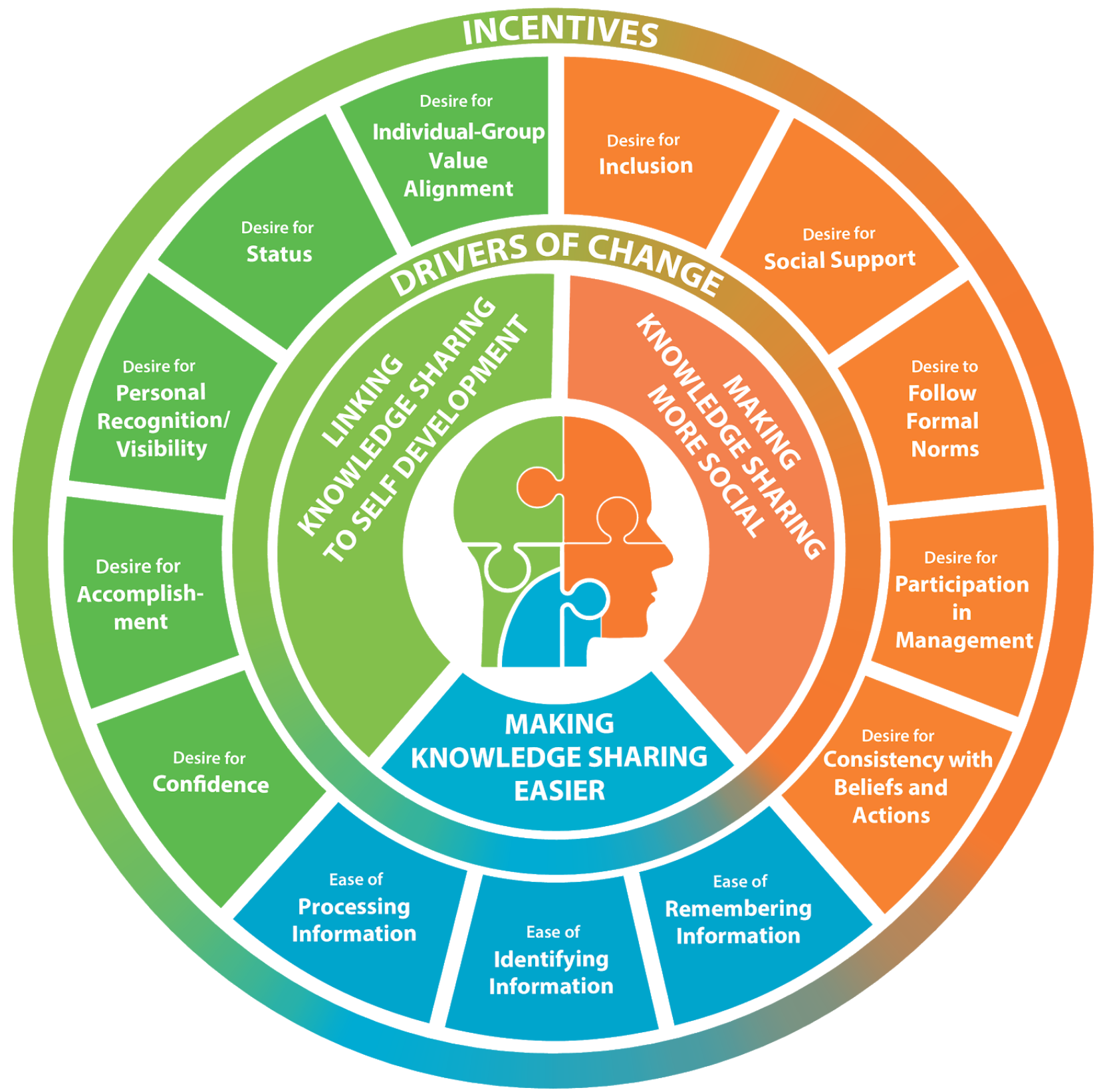

FIGURE 8: Incentive Framework for knowledge sharing-The framework is composed of 3 Drivers of Change, as well as associated incentives that can be used as behavior change tools. For full explanation of the drivers and the incentives, the readers may refer to the full report (available upon request). 


\section{Appendix III: Stock-taking-Current Incentives across the WB}

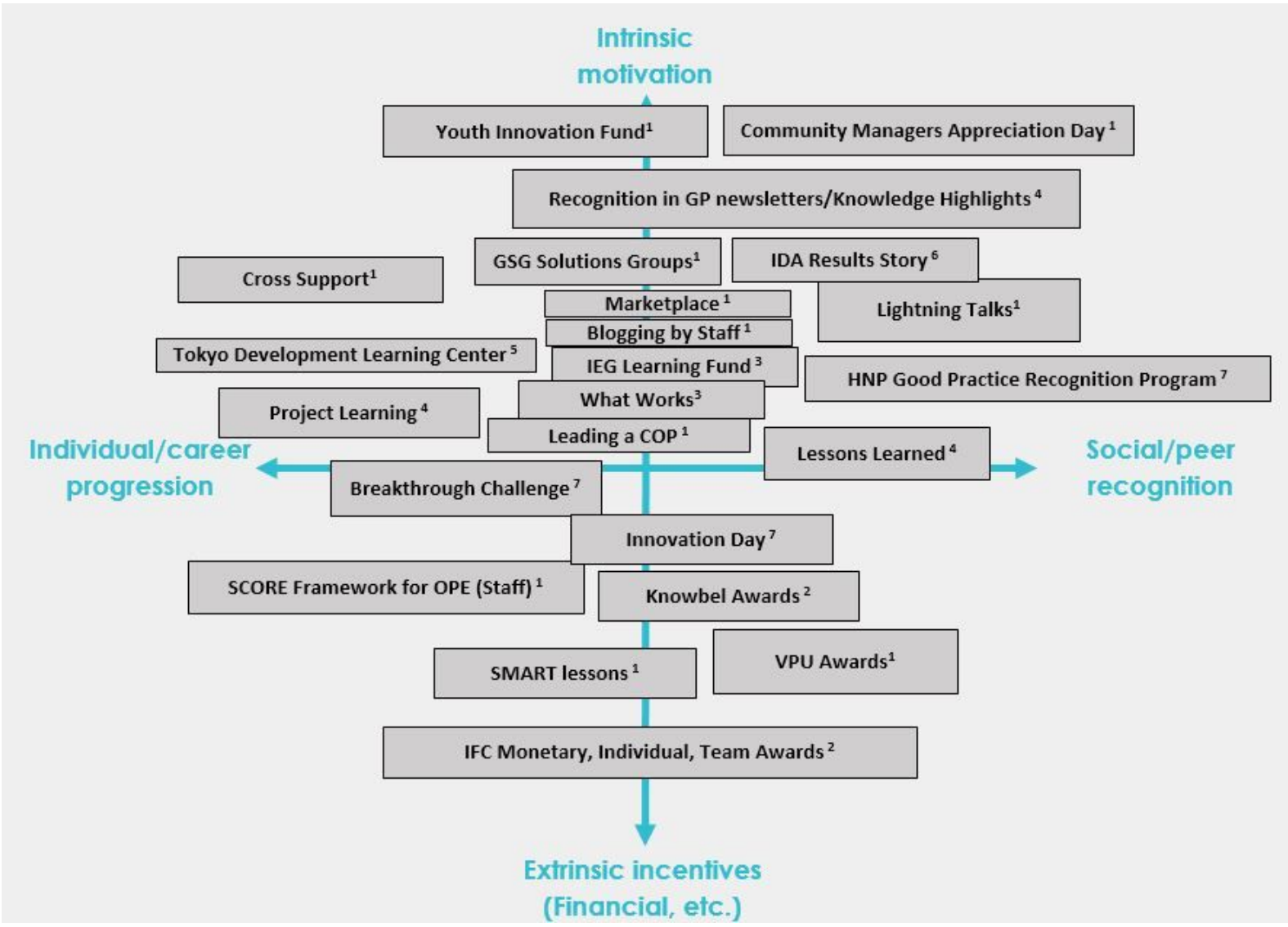

FIGURE 9: Example incentives existing at the WB

TABLE 3: Overview of existing incentives at the WB

\begin{tabular}{|c|c|c|c|c|c|}
\hline Level & Type & Driving Theme & Initiated by & Tarset Audience & Incentive \\
\hline Corporate-wide & Marketplace & Data Fair & $\begin{array}{l}\text { Development Data Council (DEC- } \\
\text { Poverty GP) }\end{array}$ & Development data scientists & Seek opportunity to collaborate \\
\hline Corporate-wide & Lightening Talk & Data Day & $\begin{array}{l}\text { Development Data Council (DEC- } \\
\text { Poverty GP) }\end{array}$ & All poverty staff & Speaker's self-promo and project promo \\
\hline Corporate-wide & Competition & Youth Innovation Fund & President's Office & $\begin{array}{l}\text { Staff and consultants below } \\
35 \text { vrs }\end{array}$ & $\begin{array}{l}\text { Work on Bank project; cross support; project } \\
\text { funding }\end{array}$ \\
\hline Corporate-wide & & $\begin{array}{l}\text { Community Managers } \\
\text { Appreciation Day }\end{array}$ & & & \\
\hline Corporate-wide & & Marketplace & & & \\
\hline Corporate-wide & & Lightning Talk & & & \\
\hline Corporate-wide & Experience & Cross Support & & All staff \& consultants & Experience in area of interest \\
\hline Corporate-wide & Experience & GSG Solutions Groups & & All staff \& consultants & Peer \& management recognition \\
\hline Corporate-wide & Story & Blogging by Staff & ECR & $\begin{array}{l}\text { All WB } \\
\text { staff/consultants/external }\end{array}$ & Peer \& management recognition \\
\hline Corporate-wide & Learning Exchange & Leading a COP & & All WB staff \& consultants & Peer \& management recognition \\
\hline Corporate-Wide & OPE & SCORE Framework for OPE & IFC & All WBG staff & Career progression \\
\hline Corporate-wide & Story & SMART Lessons & & All WBG staff & $\begin{array}{l}\text { Monetary reward; peer \& management } \\
\text { recognition }\end{array}$ \\
\hline Corporate-wide & Learning Exchange & DIME Analytics & DEC & All operations/M\&E staff & Career progression \\
\hline GP & Story & Recognition in GP Newsletters & & All GP staff & Peer recognition \\
\hline GP & Learning Exchange & $\begin{array}{l}\text { Tokyo Development Learning } \\
\text { Center }\end{array}$ & GPSURR & GP staff \& external & Peer recognition; management recognition \\
\hline GP & Story & Blogging by GP thought leaders & Poverty GP Sr. Director & GH level staff & Cultivate in $\mathrm{H}$ level career duty \\
\hline GP & Competition & $\begin{array}{l}\text { Breakthrough Challenge } \\
\text { Initiative }\end{array}$ & Poverty GP Sr. Director & Poverty GP TTLS & Extra funding \\
\hline
\end{tabular}




\begin{tabular}{|c|c|c|c|c|c|}
\hline Level & Type & Driving Theme & Initiated by & Target Audience & Incentive \\
\hline GP & Story & Lessons Learned & & GP staff \& consultants & Peer \& management recognition \\
\hline GP & Award & $\begin{array}{l}\text { HNP Good Practice Recognition } \\
\text { Program }\end{array}$ & HNP GP & GP staff \& consultants & $\begin{array}{l}\text { Award; Management recognition } \\
\text { (knowledge creation one of four categories) }\end{array}$ \\
\hline GP & Learning Exchange & Citywide Inclusive Sanitation & Water GP & $\begin{array}{l}\text { GP staff \& } \\
\text { consultants/external }\end{array}$ & Peer \& external recognition \\
\hline GP & Learning Exchange & Disaster Risk Finance COP & $\mathrm{FCl} \mathrm{GP}$ & $\begin{array}{l}\text { GP staff \& } \\
\text { consultants/external }\end{array}$ & Peer \& external recognition \\
\hline GP & Competition & Innovation Day & Poverty GP Sr. Director & All poverty staff & $\begin{array}{l}\text { Prize (project funding), recognition from GP } \\
\text { management }\end{array}$ \\
\hline GP & Learning Exchange & $\begin{array}{l}\text { Easter Partnership Transport } \\
\text { Panel Community }\end{array}$ & Transport GP & $\begin{array}{l}\text { GP } \\
\text { staff/consultants/external }\end{array}$ & Peer \& external recognition \\
\hline GP & Learning Exchange & $\begin{array}{l}\text { Transit-oriented Development } \\
\text { Community of }\end{array}$ & Transport GP & $\begin{array}{l}\text { GP } \\
\text { staff/consultants/external }\end{array}$ & Peer \& external recognition \\
\hline GP & Learning Exchange & Urbanscapes & GPSURR & $\begin{array}{l}\text { GP } \\
\text { staff/consultants/external }\end{array}$ & Peer \& external recognition \\
\hline EFI cluster & Story & IDA Results Stories & EFIVP & EFI TTLS & Recognition from EFI management \\
\hline EFI cluster & Competition & VPU Award & EFI VP & EFITTLS & $\begin{array}{l}\text { Prize (monetary), recognition from EFI } \\
\text { management (ceremony) }\end{array}$ \\
\hline IEG \& GP & Competition & IEG Learning Fund & IEG & IEG \& GP staff/consultants & Funding; peer recognition; client recognition \\
\hline IEG & Story & What works & IEG & IEG staff \& consultants & Peer recognition; management recognition \\
\hline IFC & Award & Knowbel Awards & IFC & All IFC staff & $\begin{array}{l}\text { Monetary reward; peer \& management } \\
\text { recognition }\end{array}$ \\
\hline IFC & Award & IFC Team \& Individual Awards & IFC & All IFC staff & $\begin{array}{l}\text { Monetary reward; peer \& management } \\
\text { recognition }\end{array}$ \\
\hline HR & Learning Exchange & HR Analytics COP & HR & All HR staff & Peer \& management recognition 3 \\
\hline
\end{tabular}




\section{Appendix IV: Process and Methodology Employed}

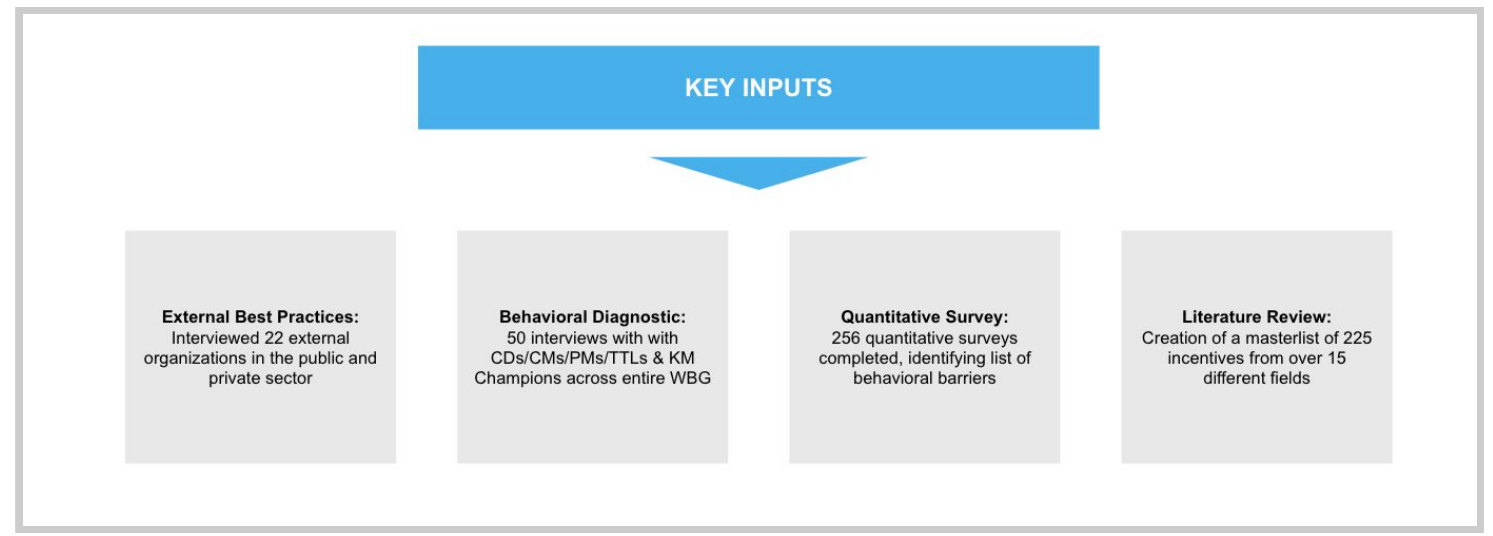

FIGURE 10: Overview of research inputs.

1. External Best Practices: Interviewed 22 external organizations in the public and private sector, which led to a list of $40+$ incentives.

Large organizations incentivize knowledge sharing in distinct ways whereby 40 of the most common Knowledge Sharing Incentives were summed up and categorized by 9 dimensions:

1. Top Down Knowledge Sharing Incentives

2. External Exposure (event participation/publications, etc.)

3. Work Environment Design

4. Official Career Progression

5. Social/Peer Recognition

6. Internal Exposure through formal recognition

7. Technology Enhanced Incentives

8. Direct Rewards

9. Intrinsic Motivation

The external research on incentives was supplemented by a literature review of previous WB work on knowledge sharing, which led to the creation of a comprehensive list of knowledge sharing incentives.

2. Behavioral Diagnostic: Fifty interviews were conducted with $\mathrm{CDs} / \mathrm{CMs} / \mathrm{PMs} / \mathrm{TTLs}$ and Knowledge Champions across the entire WB. The purpose was to gain insights into the various drivers and barriers of behavior to create the quantitative survey. 
3. Quantitative Survey: The purpose of this survey was to understand the relative significance of the key drivers and barriers of behaviors to knowledge-sharing behaviors in the WB context. Part 1 of the survey involved a series of questions related to general drivers and barriers to knowledge sharing at the Bank. Part 2 focused on five key desired behaviors (KDBs). Some of the selected KDBs are related to operational requirements of WB staff, such as completing handover packages. Other KDBs are related to non-operational behaviors, such as signing up for training unrelated to ToR. The survey collected data on both the structural and psychological components of drivers and barriers which had not been identified in the earlier data collection stages of the project.

4. Literature Review: The literature review was focused on creating a master list of over 225 incentives that exist in different industries, to find complementarity with knowledge-sharing initiatives. 


\section{Appendix V: Survey Data Collection Methodology}

The primary research design was a quantitative survey sent by e-mail to $753 \mathrm{WB}$ employees. The response rate was $34 \%$. Employees were requested to voluntarily participate in the survey. There were two versions of the survey provided for each of the five KDBs, resulting in a total of 10 variations of the survey. Links to the 10 variations of the survey were randomly sent out to the WB staff e-mail addresses.

Each of the two versions of the survey contained a different scope. Version 1 was a "Rating" survey which asked respondents to rank how much they agree with a series of statements about behaviors and drivers within the KBDs. The ranking was measured by a Likert Scale ( 1 = 'Strongly Disagree' to $7=$ 'Strongly Agree'). Version 2 was a "Listing" survey which included the same questions and scale as the rating version but contained an additional open-ended component. The open-ended response option allowed respondents to identify drivers and barriers involving both structural (e.g., tech systems) or psychological (e.g., desire to collaborate) realities that make a particular behavior more or less likely to occur.

Information from World Bank employees on key desired behaviors that cover both barriers and drivers was collected. The five KDBs included:

1. Handover packages

2. Joint missions

3. Top 10 issues to tackle

4. Sharing short relevant punchy pieces

5. Proactive sign-ups for trainings unrelated to ToR 
TABLE 4: Survey responses

\begin{tabular}{|l|c|}
\hline Type & Number of Surveys \\
\hline Staff surveys & 256 (34\% response rate) \\
\hline Topics & \\
\hline KDB1: Handover package—Staff creates an adequate handover package & 41 \\
\hline $\begin{array}{l}\text { KDB2: Joint mission—Outgoing TTL goes on joint mission with } \\
\text { incoming TTL }\end{array}$ & 44 \\
\hline $\begin{array}{l}\text { KDB3: Top 10 issues to tackle—Staff creates a list of Top 10 issues to } \\
\text { tackle during a handover }\end{array}$ & 64 \\
\hline $\begin{array}{l}\text { KDB4: Sharing relevant short posts—Staff shares short relevant punchy } \\
\text { pieces }\end{array}$ & \\
\hline $\begin{array}{l}\text { KDB5: Proactive sign-ups for trainings-Staff engages in training } \\
\text { unrelated to their ToR }\end{array}$ & 54 \\
\hline
\end{tabular}

\section{Codification of Drivers and Barriers within KDBs}

The identified Drivers and Barriers were codified according to Behavior Change Frameworks which identify them as: opportunistic (Physical or Social), motivational (Reflective or Automatic) or related to capability (Psychological or Physical (Capability)). In the following results sections the drivers and barriers are codified following the same color scheme (Table 5).

TABLE 5: Coding guide for behavioral change framework classifications

\begin{tabular}{|c|c|c|}
\hline Opportunity & Motivation & Capability \\
\hline Physical & Reflective & Psychological \\
\hline Social & Automatic & Physical (capability) \\
\hline
\end{tabular}




\section{Key Findings}

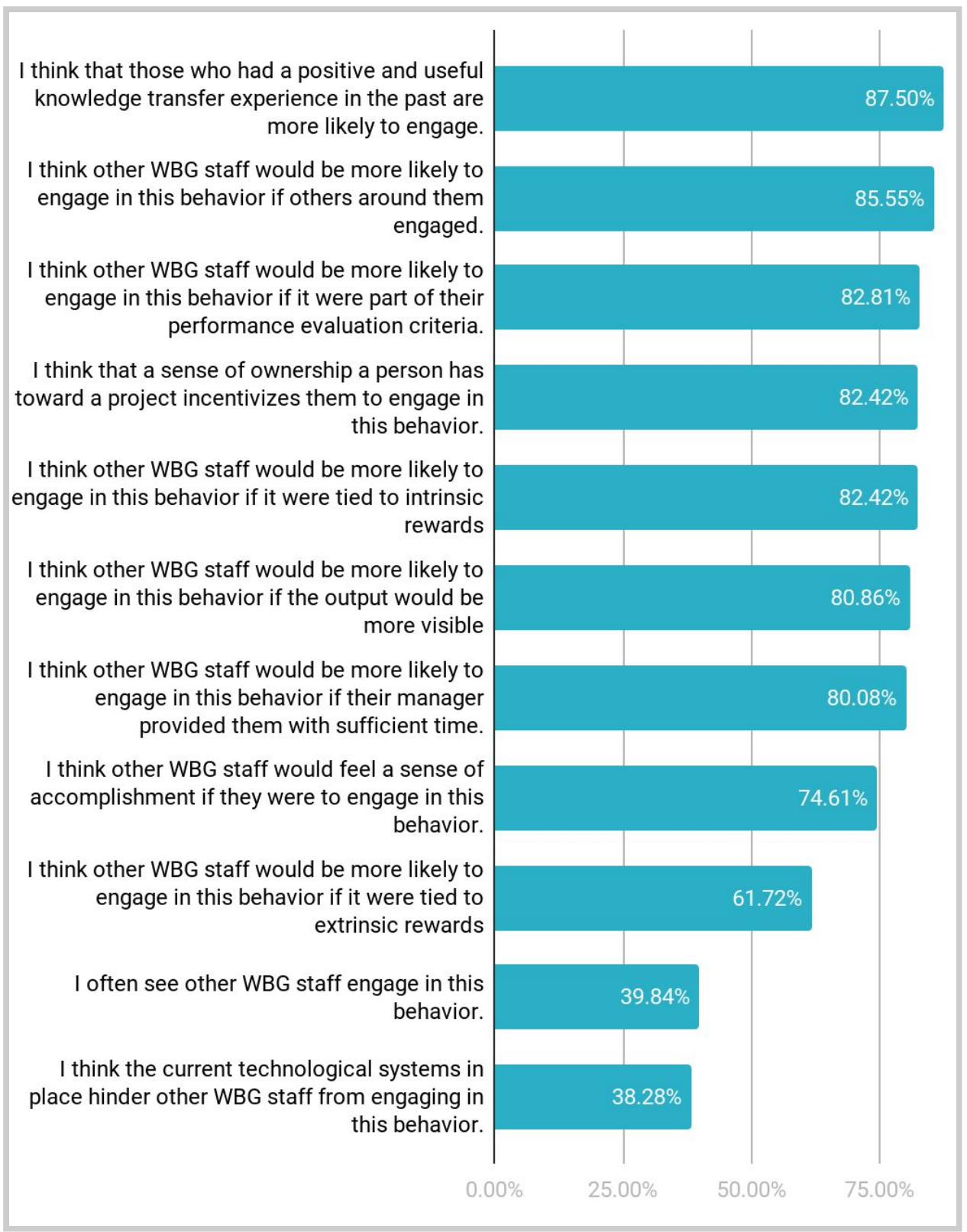

GRAPH 1: Top \% of respondents who agreed with statements related to KM. 


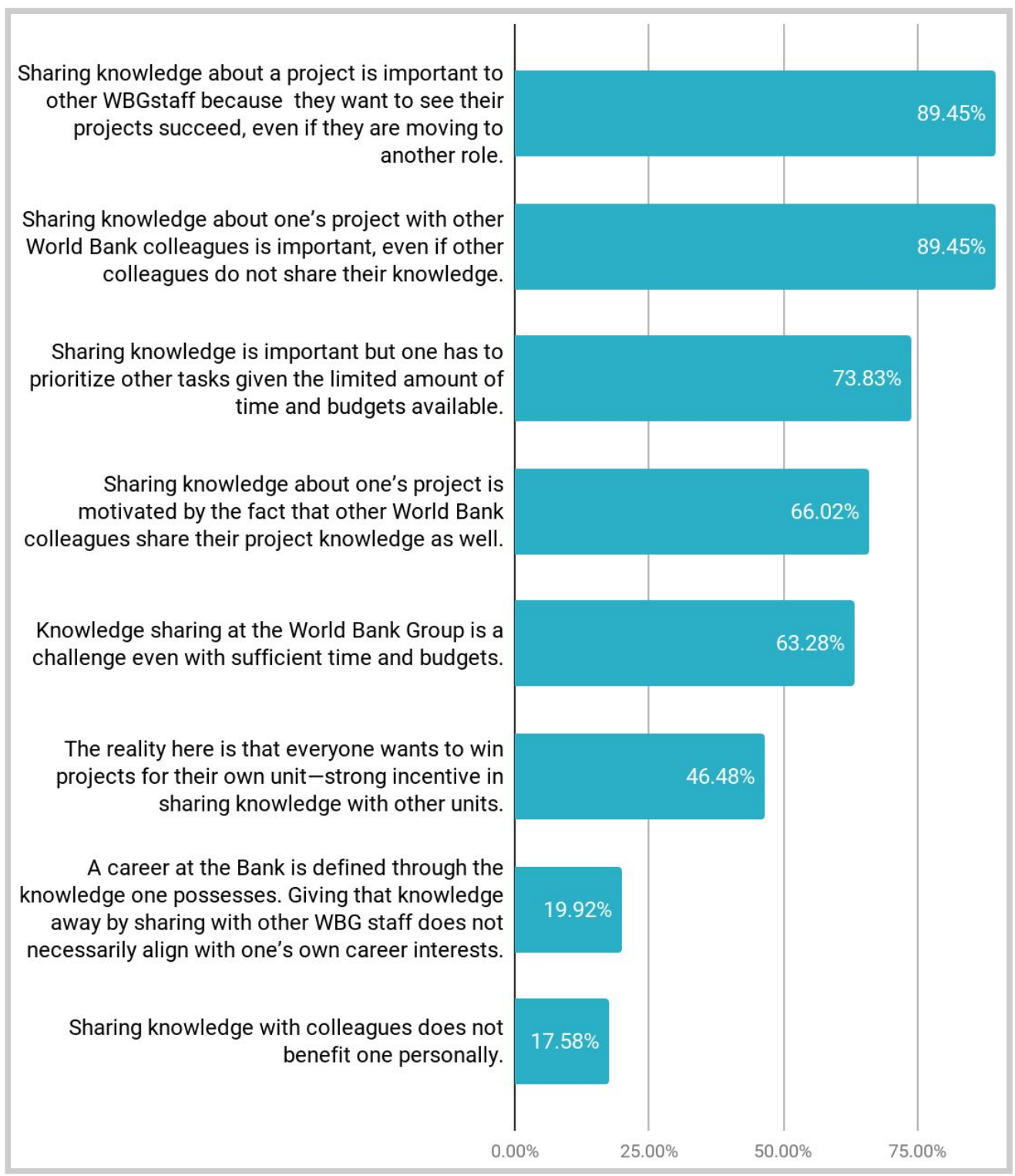

GRAPH 2: Top \% of respondents who agreed with statements related to KM. 


\section{KDB1-Handover Package}

\section{Barriers to Behavior}

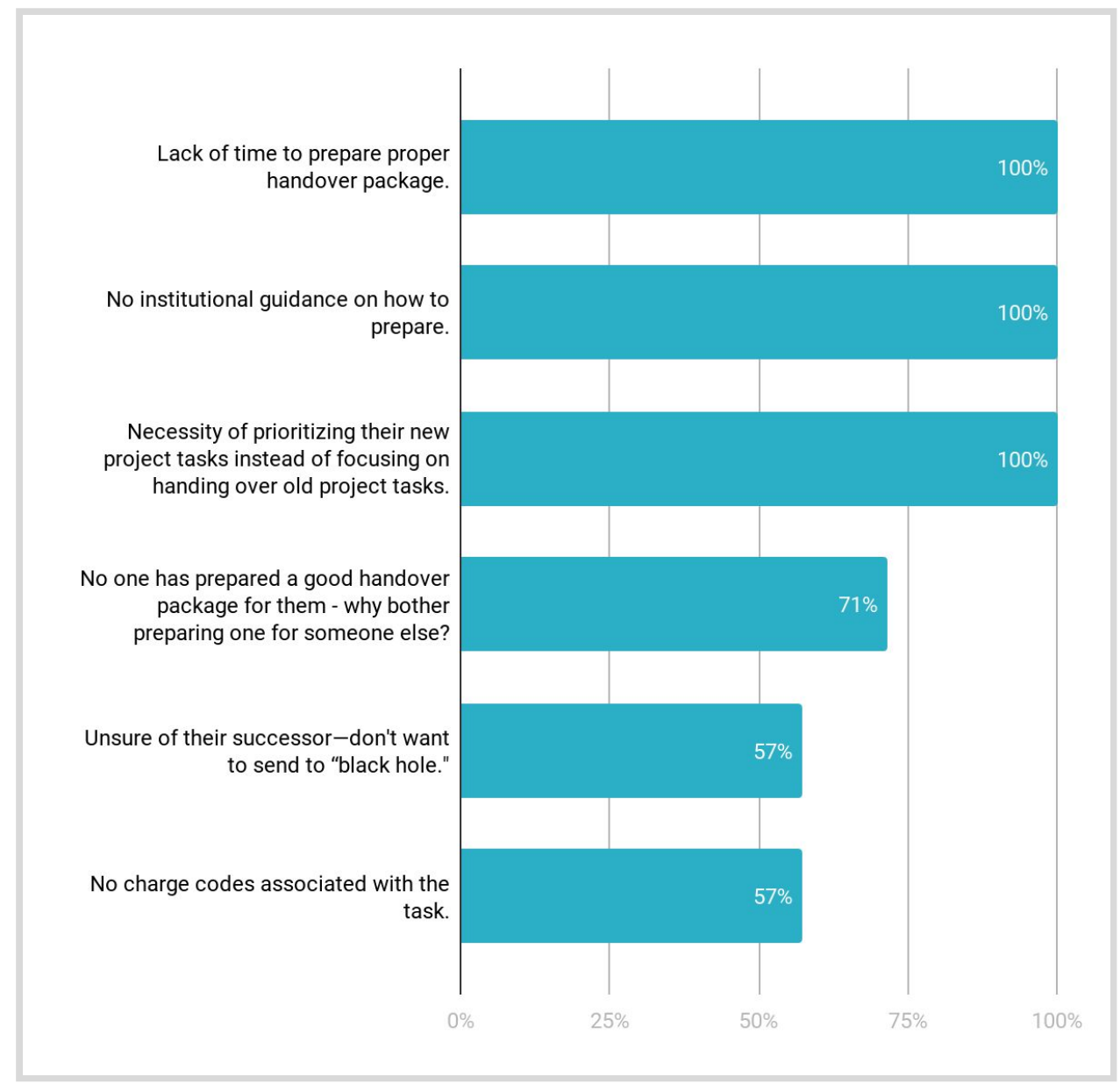

GRAPH 3: GRAPH 2: Top \% of respondents who agreed with statements related to KM. 
TABLE 6: Barriers to handover packages identified by respondents and their corresponding behavior change category based on the COM-B behavioral diagnostic framework

\begin{tabular}{l|l|l|l|l|l}
$\begin{array}{l}\text { No strong } \\
\text { extrinsic } \\
\text { incentive }\end{array}$ & $\begin{array}{l}\text { Reciprocity is } \\
\text { fairly limited }\end{array}$ & $\begin{array}{l}\text { Lack of a } \\
\text { standard } \\
\text { template for } \\
\text { sharing } \\
\text { information }\end{array}$ & $\begin{array}{l}\text { Large work } \\
\text { programs }\end{array}$ & $\begin{array}{l}\text { Delaying the } \\
\text { task until } \\
\text { everything else } \\
\text { is done }\end{array}$ & Silo culture \\
\hline Negligence & $\begin{array}{l}\text { Someone else } \\
\text { will eventually } \\
\text { do it }\end{array}$ & $\begin{array}{l}\text { Not considering } \\
\text { the task to be a } \\
\text { priority }\end{array}$ & $\begin{array}{l}\text { Misconceptions } \\
\text { of some of the } \\
\text { Bank's senior } \\
\text { management }\end{array}$ & $\begin{array}{l}\text { More direct } \\
\text { rewards needed }\end{array}$ & $\begin{array}{l}\text { Lack of clarity } \\
\text { on what is } \\
\text { useful/expected }\end{array}$ \\
\hline $\begin{array}{l}\text { Organizational } \\
\text { structure }\end{array}$ & $\begin{array}{l}\text { Limited budget } \\
\text { resources }\end{array}$ & $\begin{array}{l}\text { Fear of exposing } \\
\text { weaknesses }\end{array}$ & $\begin{array}{l}\text { Inequities due to } \\
\text { lack of candor in } \\
\text { staff evaluation }\end{array}$ & $\begin{array}{l}\text { Small number of } \\
\text { role models }\end{array}$ & $\begin{array}{l}\text { DECK and } \\
\text { operational } \\
\text { units are } \\
\text { divorced }\end{array}$ \\
\hline $\begin{array}{l}\text { Short transition } \\
\text { times }\end{array}$ & $\begin{array}{l}\text { Limited } \\
\text { dedicated staff } \\
\text { time }\end{array}$ & $\begin{array}{l}\text { Lack of team } \\
\text { spirit }\end{array}$ & $\begin{array}{l}\text { No concern of } \\
\text { continuity }\end{array}$ & $\begin{array}{l}\text { Lack of cross GP } \\
\text { collaboration }\end{array}$ & $\begin{array}{l}\text { Pressure to } \\
\text { deliver own ops }\end{array}$ \\
\hline
\end{tabular}

TABLE 7: Barriers by Com-B category

\begin{tabular}{|l|c|}
\hline Behavior Change Category & Count \\
\hline Automatic & 0 \\
\hline Reflective & 6 \\
\hline Social & 7 \\
\hline Physical & 11 \\
\hline
\end{tabular}




\section{Drivers of Behavior}

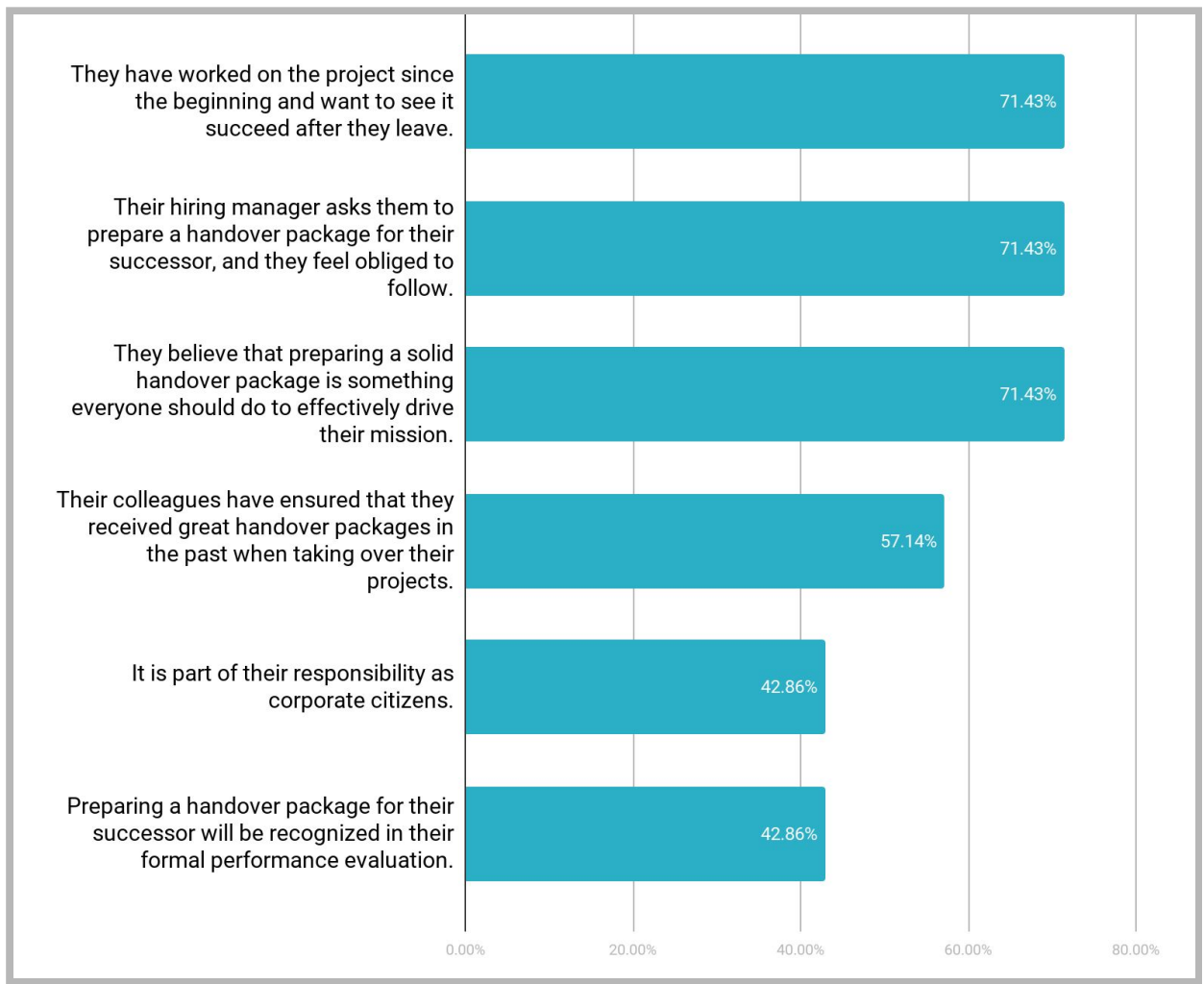

GRAPH 4: Top \% of respondents who agreed with statements related to drivers to Handover Packages.

TABLE 8: Drivers to handover packages identified by respondents and their corresponding behavior change category based on the COM-B behavioral diagnostic framework

\begin{tabular}{|l|l|l|l|l|l}
\hline $\begin{array}{l}\text { Tech system } \\
\text { can be } \\
\text { improved }\end{array}$ & $\begin{array}{l}\text { Better } \\
\text { collaboration } \\
\text { environments }\end{array}$ & $\begin{array}{l}\text { A proper } \\
\text { transition } \\
\text { manual has } \\
\text { been created }\end{array}$ & $\begin{array}{l}\text { Make it a part } \\
\text { of PM } \\
\text { performance }\end{array}$ & $\begin{array}{l}\text { Important for } \\
\text { networking }\end{array}$ & $\begin{array}{l}\text { Sense of } \\
\text { ownership }\end{array}$ \\
\hline $\begin{array}{l}\text { Recognition of } \\
\text { effort }\end{array}$ & Reciprocity & $\begin{array}{l}\text { Standard } \\
\text { templates and } \\
\text { tech systems }\end{array}$ & $\begin{array}{l}\text { True } \\
\text { motivation }\end{array}$ & $\begin{array}{l}\text { Active } \\
\text { counterpart }\end{array}$ & $\begin{array}{l}\text { Provide } \\
\text { adequate ACS }\end{array}$ \\
\hline $\begin{array}{l}\text { Monetary } \\
\text { compensation/ } \\
\text { incentive }\end{array}$ & $\begin{array}{l}\text { Boost ACS } \\
\text { capacity for } \\
\text { TTLs handover }\end{array}$ & $\begin{array}{l}\text { A supportive } \\
\text { manager }\end{array}$ & $\begin{array}{l}\text { A proactive } \\
\text { communication } \\
\text { sofficer }\end{array}$ & $\begin{array}{l}\text { Boost } \\
\text { appreciation }\end{array}$ & $\begin{array}{l}\text { Change silo } \\
\text { culture }\end{array}$ \\
\hline $\begin{array}{l}\text { Collaboration } \\
\text { and networking }\end{array}$ & $\begin{array}{l}\text { Manager } \\
\text { leading by } \\
\text { example }\end{array}$ & $\begin{array}{l}\text { Formal } \\
\text { knowledge-sha } \\
\text { ring process }\end{array}$ & $\begin{array}{l}\text { IT facilities for } \\
\text { knowledge } \\
\text { sharing }\end{array}$ & $\begin{array}{l}\text { Better balance } \\
\text { of workload }\end{array}$ & $\begin{array}{l}\text { More } \\
\text { gatherings of } \\
\text { staff }\end{array}$ \\
\hline
\end{tabular}




\begin{tabular}{|c|c|c|c|c|c|}
\hline $\begin{array}{l}\text { Fewer } \\
\text { helpdesks }\end{array}$ & $\begin{array}{l}\text { More candid } \\
\text { feedback in } \\
\text { evaluation }\end{array}$ & $\begin{array}{l}\text { Rewards } \\
\text { offered for } \\
\text { completion }\end{array}$ & Time afforded & $\begin{array}{l}\text { Early } \\
\text { knowledge of } \\
\text { the transition }\end{array}$ & $\begin{array}{l}\text { Early } \\
\text { introduction to } \\
\text { the team/TTL } \\
\text { taking over the } \\
\text { task }\end{array}$ \\
\hline $\begin{array}{l}\text { Better planned } \\
\text { pre-assignment } \\
\text { missions }\end{array}$ & $\begin{array}{l}\text { Early } \\
\text { introduction of } \\
\text { new members } \\
\text { to the wider } \\
\text { team }\end{array}$ & $\begin{array}{l}\text { Dedicated staff } \\
\text { time for } \\
\text { knowledge } \\
\text { sharing }\end{array}$ & $\begin{array}{l}\text { Clear } \\
\text { promotion } \\
\text { criteria for } \\
\text { senior level } \\
\text { technical } \\
\text { experts }\end{array}$ & Self-interest & Oversight \\
\hline $\begin{array}{l}\text { Penalty for } \\
\text { failure to create } \\
\text { a package }\end{array}$ & $\begin{array}{l}\text { Opportunities } \\
\text { for promotion } \\
\text { or } \\
\text { advancement }\end{array}$ & $\begin{array}{l}\text { Requirement or } \\
\text { regulation }\end{array}$ & $\begin{array}{l}\text { Increased } \\
\text { budget }\end{array}$ & $\begin{array}{l}\text { DECK more } \\
\text { accountable to } \\
\text { operations and } \\
\text { countries }\end{array}$ & Include in OPE \\
\hline $\begin{array}{l}\text { Give specific } \\
\text { budget lines to } \\
\text { the task }\end{array}$ & $\begin{array}{l}\text { Make it part of } \\
\text { project KPI }\end{array}$ & $\begin{array}{l}\text { Explicit } \\
\text { encouragement } \\
\text { from your } \\
\text { director/VP to } \\
\text { work on } \\
\text { knowledge } \\
\text { sharing }\end{array}$ & $\begin{array}{l}\text { Easier } \\
\text { procedures to } \\
\text { file }\end{array}$ & $\begin{array}{l}\text { More creativity } \\
\text { from Bank, i.e., } \\
\text { innovate in } \\
\text { social networks }\end{array}$ & $\begin{array}{l}\text { Belief that } \\
\text { sharing } \\
\text { knowledge } \\
\text { leads to better } \\
\text { outcomes/ } \\
\text { impacts }\end{array}$ \\
\hline
\end{tabular}

\section{TABLE 9: Drivers by Com-B category}

\begin{tabular}{|l|c|}
\hline Behavior Change Category & Count \\
\hline Automatic & 0 \\
\hline Reflective & 6 \\
\hline Social & 26 \\
\hline Physical & 16 \\
\hline
\end{tabular}




\section{KDB2-Joint Missions}

\section{Barriers to Joint Missions}

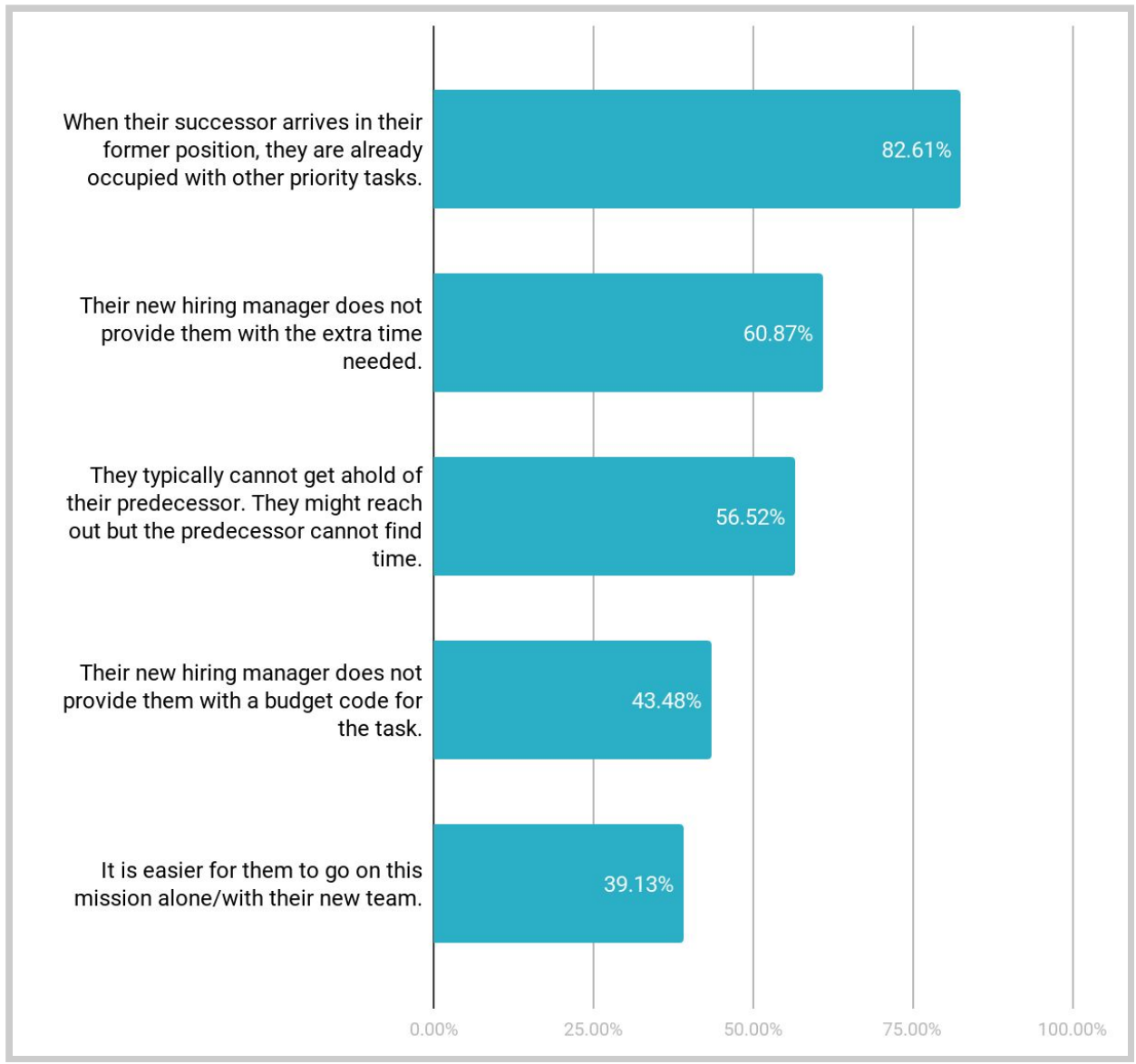

GRAPH 5: Top \% of respondents who agreed with statements related to barriers to Joint Missions.

TABLE 10: Barriers to joint missions identified by respondents and their corresponding behavior change category based on the COM-B behavioral diagnostic framework

\begin{tabular}{l|l|l|l|l|l}
$\begin{array}{l}\text { SRI curve } \\
\text { creates } \\
\text { perverse/competi } \\
\text { tive behaviors }\end{array}$ & $\begin{array}{l}\text { Lack of formal } \\
\text { and informal } \\
\text { recognition }\end{array}$ & $\begin{array}{l}\text { Lack of formal } \\
\text { process to } \\
\text { conduct } \\
\text { transition }\end{array}$ & $\begin{array}{l}\text { Lack of } \\
\text { accountability to } \\
\text { conduct } \\
\text { handover }\end{array}$ & $\begin{array}{l}\text { Misalignment } \\
\text { between } \\
\text { performance } \\
\text { objectives and } \\
\text { knowledge } \\
\text { sharing }\end{array}$ & $\begin{array}{l}\text { No formal } \\
\text { knowledge- } \\
\text { sharing } \\
\text { protocols/guideli } \\
\text { nes of good } \\
\text { practices }\end{array}$ \\
\hline $\begin{array}{l}\text { Knowledge } \\
\text { sharing looks } \\
\text { like bragging }\end{array}$ & Time costs & $\begin{array}{l}\text { 'Bandwidth'- } \\
\text { limited time } \\
\text { available relative } \\
\text { to other priorities }\end{array}$ & $\begin{array}{l}\text { It can be treated } \\
\text { as imposing } \\
\text { one's viewpoint } \\
\text { upon the } \\
\text { incoming team }\end{array}$ & $\begin{array}{l}\text { Organizational } \\
\text { job insecurity } \\
\text { triggering } \\
\text { competitive and } \\
\text { individualistic } \\
\text { behaviors }\end{array}$ & $\begin{array}{l}\text { Management } \\
\text { interest and } \\
\text { attention on } \\
\text { encouraging this } \\
\text { behavior widely } \\
\text { across teams }\end{array}$ \\
\hline
\end{tabular}




\begin{tabular}{|c|c|c|c|c|c|}
\hline $\begin{array}{l}\text { Insufficient } \\
\text { recognition }\end{array}$ & $\begin{array}{l}\text { Handovers } \\
\text { between TTLs } \\
\text { can be hampered } \\
\text { by limited } \\
\text { budgets for } \\
\text { mission travel }\end{array}$ & $\begin{array}{l}\text { Lack of } \\
\text { incentives }\end{array}$ & $\begin{array}{l}\text { No punishment if } \\
\text { there is no } \\
\text { knowledge } \\
\text { sharing }\end{array}$ & $\begin{array}{l}\text { Insufficient time } \\
\text { and skills to } \\
\text { document } \\
\text { learning } \\
\text { systematically by } \\
\text { self }\end{array}$ & $\begin{array}{l}\text { Budget to bring } \\
\text { in an external } \\
\text { resource person } \\
\text { to capture the } \\
\text { learning and put } \\
\text { it in a } \\
\text { ready-to-use } \\
\text { format }\end{array}$ \\
\hline $\begin{array}{l}\text { Overlapping staff } \\
\text { positions during } \\
\text { transition }\end{array}$ & Lack of interest & $\begin{array}{l}\text { Unwillingness to } \\
\text { share knowledge }\end{array}$ & $\begin{array}{l}\text { Undervaluing of } \\
\text { knowledge } \\
\text { sharing in } \\
\text { professional } \\
\text { evaluations/reput } \\
\text { ation }\end{array}$ & $\begin{array}{l}\text { Greater emphasis } \\
\text { at Bank on } \\
\text { working on } \\
\text { many different } \\
\text { projects rather } \\
\text { than doing fewer } \\
\text { things well }\end{array}$ & $\begin{array}{l}\text { Hard to make } \\
\text { people care } \\
\text { about it }\end{array}$ \\
\hline $\begin{array}{l}\text { Different sets of } \\
\text { priorities in new } \\
\text { role }\end{array}$ & $\begin{array}{l}\text { No culture of } \\
\text { information } \\
\text { sharing }\end{array}$ & $\begin{array}{l}\text { Competition } \\
\text { between the units }\end{array}$ & $\begin{array}{l}\text { Absence of a } \\
\text { clear recording } \\
\text { mechanism }\end{array}$ & $\begin{array}{l}\text { Fragmented } \\
\text { approach }\end{array}$ & $\begin{array}{l}\text { Lack of broad } \\
\text { country } \\
\text { perspective }\end{array}$ \\
\hline $\begin{array}{l}\text { Lack of } \\
\text { sequencing and } \\
\text { synergies }\end{array}$ & $\begin{array}{l}\text { Siloed approach } \\
\text { from GPs }\end{array}$ & $\begin{array}{l}\text { Lack of strong } \\
\text { managerial } \\
\text { oversight }\end{array}$ & $\begin{array}{l}\text { Lack of intrinsic } \\
\text { motivation }\end{array}$ & $\begin{array}{l}\text { Personal reasons } \\
\text { that may keep } \\
\text { people from } \\
\text { traveling }\end{array}$ & $\begin{array}{l}\text { Accountability } \\
\text { and } \\
\text { Decision-Making } \\
\text { cannot be shared }\end{array}$ \\
\hline $\begin{array}{l}\text { Territoriality; } \\
\text { people can act } \\
\text { immaturely in } \\
\text { their roles }\end{array}$ & $\begin{array}{l}\text { Lack of team } \\
\text { spirit }\end{array}$ & $\begin{array}{l}\text { There is less } \\
\text { accountability } \\
\text { for failing to } \\
\text { deliver } \\
\text { knowledge } \\
\text { components }\end{array}$ & $\begin{array}{l}\text { Knowledge } \\
\text { resources are not } \\
\text { monitored as } \\
\text { seriously as } \\
\text { investment } \\
\text { resources }\end{array}$ & $\begin{array}{l}\text { You worry that } \\
\text { the knowledge } \\
\text { you helped to } \\
\text { create is not of } \\
\text { any use }\end{array}$ & \\
\hline
\end{tabular}

TABLE 11: Barriers by Com-B category

\begin{tabular}{|l|c|}
\hline Behavior Change Category & Count \\
\hline Automatic & 1 \\
\hline Reflective & 9 \\
\hline Social & 23 \\
\hline Physical & 8 \\
\hline
\end{tabular}




\section{Drivers for Joint Missions}

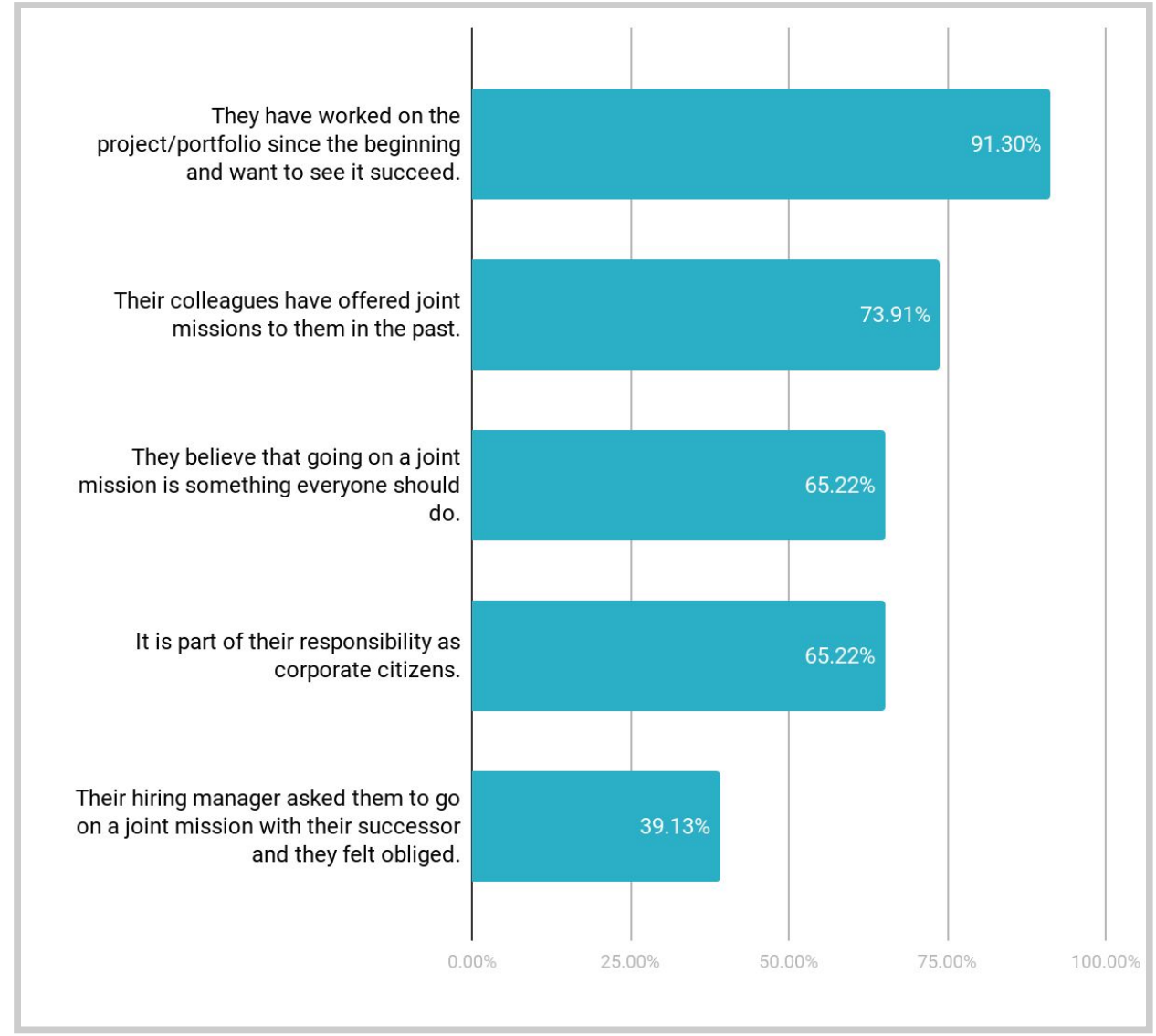

GRAPH 6: Top \% of respondents who agreed with statements related to drivers to Joint Missions

TABLE 12: Drivers to joint mission identified by respondents and their corresponding behavior change category based on the COM-B behavioral diagnostic framework

\begin{tabular}{|c|c|c|c|c|c|}
\hline $\begin{array}{l}\text { Structured } \\
\text { approach for } \\
\text { transition } \\
\text { handover }\end{array}$ & $\begin{array}{l}\text { Recognition of } \\
\text { staff who did a } \\
\text { good job handing } \\
\text { over knowledge }\end{array}$ & $\begin{array}{l}\text { Specific } \\
\text { reference to } \\
\text { knowledge } \\
\text { sharing and } \\
\text { inclusion in the } \\
\text { year-end } \\
\text { performance } \\
\text { summary }\end{array}$ & $\begin{array}{l}\text { Engaged team to } \\
\text { be part of } \\
\text { transition process }\end{array}$ & $\begin{array}{l}\text { Recognition by } \\
\text { management and } \\
\text { peers }\end{array}$ & $\begin{array}{l}\text { Somewhere in } \\
\text { OPE form to } \\
\text { document the } \\
\text { actions }\end{array}$ \\
\hline $\begin{array}{l}\text { A fund for } \\
\text { learning missions }\end{array}$ & $\begin{array}{l}\text { Management } \\
\text { encourages and } \\
\text { recognizes such } \\
\text { behaviors }\end{array}$ & $\begin{array}{l}\text { Peers recognize } \\
\text { and value } \\
\text { collaboration }\end{array}$ & $\begin{array}{l}\text { Collaboration } \\
\text { and knowledge } \\
\text { sharing seen as } \\
\text { integral to } \\
\text { mentoring role }\end{array}$ & $\begin{array}{l}\text { Clear } \\
\text { information } \\
\text { sharing } \\
\text { organizational } \\
\text { rituals with } \\
\text { associated } \\
\text { incentives }\end{array}$ & $\begin{array}{l}\text { Value added } \\
\text { sharing }\end{array}$ \\
\hline $\begin{array}{l}\text { Tribe, } \\
\text { community, } \\
\text { "family," sorority } \\
\text { sense - one for } \\
\text { all, all for one } \\
\text { culture }\end{array}$ & $\begin{array}{l}\text { A sense that their } \\
\text { efforts would be } \\
\text { continued }\end{array}$ & $\begin{array}{l}\text { Better systems to } \\
\text { implement the } \\
\text { program }\end{array}$ & $\begin{array}{l}\text { Culture of } \\
\text { openness and } \\
\text { celebration of } \\
\text { mistakes }\end{array}$ & $\begin{array}{l}\text { Making it part of } \\
\text { OPE targets and } \\
\text { professional } \\
\text { development }\end{array}$ & $\begin{array}{l}\text { Making it part } \\
\text { and parcel of } \\
\text { staff learning } \\
\text { week (extend the } \\
\text { days allowed if } \\
\text { necessary) }\end{array}$ \\
\hline
\end{tabular}




\begin{tabular}{|l|l|l|l|l|l}
\hline Teamwork & Shared budgets & $\begin{array}{l}\text { Sense of } \\
\text { belonging }\end{array}$ & Compensation & $\begin{array}{l}\text { A working } \\
\text { culture that } \\
\text { recognizes all the } \\
\text { people who } \\
\text { contribute }\end{array}$ & $\begin{array}{l}\text { Great potential } \\
\text { for professional } \\
\text { growth }\end{array}$ \\
\hline $\begin{array}{l}\text { Affects monetary } \\
\text { compensation/ } \\
\text { award }\end{array}$ & $\begin{array}{l}\text { Give proper } \\
\text { credit/visibility }\end{array}$ & $\begin{array}{l}\text { Sense of } \\
\text { responsibility to } \\
\text { share }\end{array}$ & $\begin{array}{l}\text { Sense of helping } \\
\text { out as much as } \\
\text { possible to } \\
\text { colleagues }\end{array}$ & $\begin{array}{l}\text { Willing to share } \\
\text { one's knowledge }\end{array}$ & $\begin{array}{l}\text { Great source of } \\
\text { learning }\end{array}$ \\
\hline $\begin{array}{l}\text { Bring country } \\
\text { program } \\
\text { visibility }\end{array}$ & $\begin{array}{l}\text { Value both client } \\
\text { and staff } \\
\text { achievements }\end{array}$ & $\begin{array}{l}\text { Visibility for } \\
\text { staff }\end{array}$ & $\begin{array}{l}\text { Intrinsic } \\
\text { motivation }\end{array}$ & $\begin{array}{l}\text { Client } \\
\text { expectation }\end{array}$ & $\begin{array}{l}\text { Push from } \\
\text { management }\end{array}$ \\
\hline $\begin{array}{l}\text { Sufficient funds } \\
\text { for missions }\end{array}$ & $\begin{array}{l}\text { Make action a } \\
\text { part of } \\
\text { performance } \\
\text { evaluations }\end{array}$ & Share ADM & $\begin{array}{l}\text { Career } \\
\text { advancement }\end{array}$ & Generosity & $\begin{array}{l}\text { Examples from } \\
\text { senior } \\
\text { management and } \\
\text { leaders }\end{array}$ \\
\hline
\end{tabular}

TABLE 13: Drivers by Com-B category

\begin{tabular}{|l|c|}
\hline Behavior Change Category & Count \\
\hline Automatic & 0 \\
\hline Reflective & 9 \\
\hline Social & 19 \\
\hline Physical & 14 \\
\hline
\end{tabular}


3. KDB3-Top 10 Issues to Tackle

\section{Barriers to Top 10 Issues to Tackle}

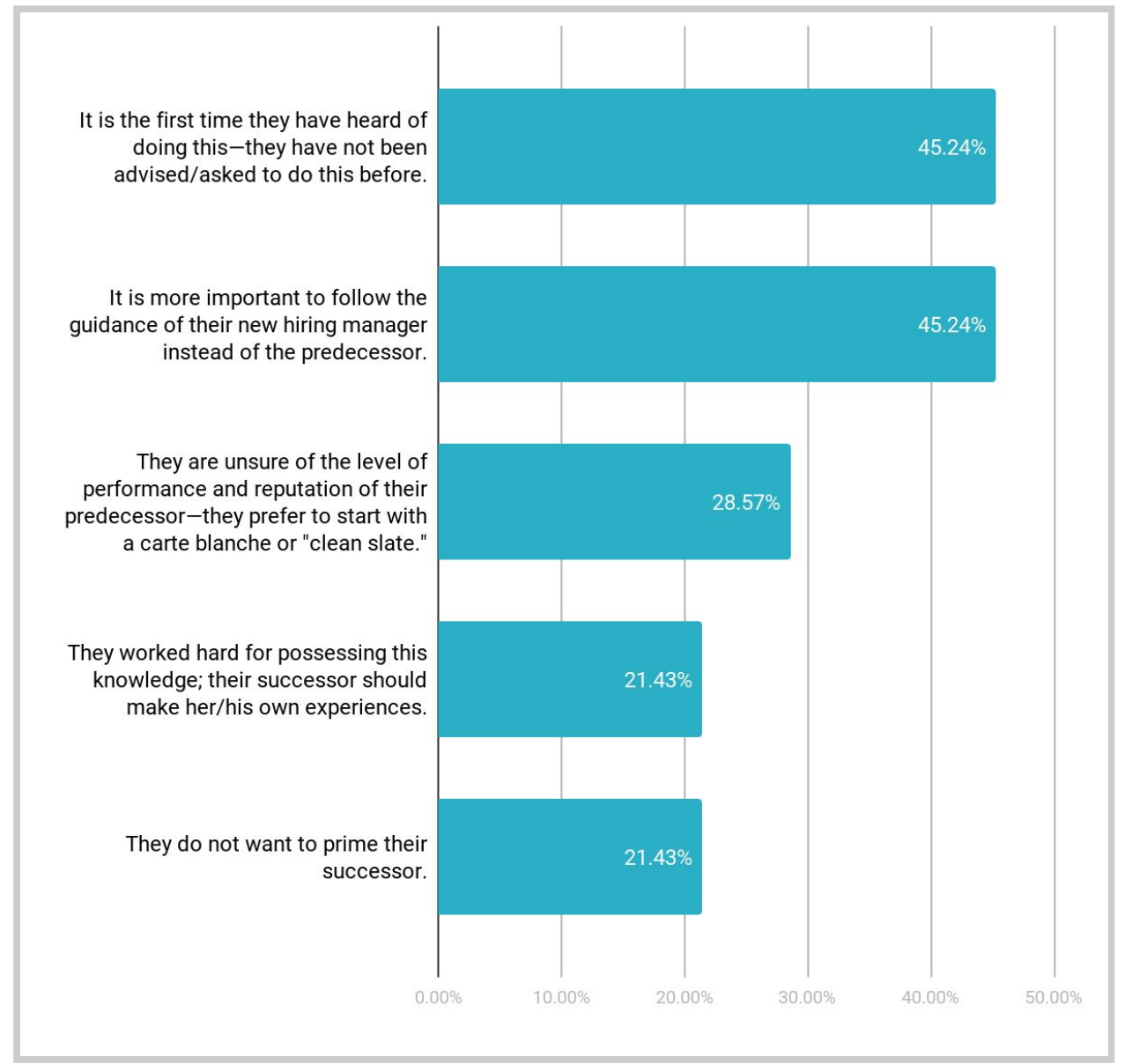

GRAPH 7: Top \% of respondents who agreed with statements related to barriers to Top 10 List of Issues 
TABLE 14: Barriers to Top 10 List of issues as identified by respondents and their corresponding behavior change category based on the COM-B behavioral diagnostic framework

\begin{tabular}{|c|c|c|c|c|c|}
\hline $\begin{array}{l}\text { Insufficient time } \\
\text { given to } \\
\text { operational } \\
\text { priorities }\end{array}$ & $\begin{array}{l}\text { Overlap at time } \\
\text { of transition }\end{array}$ & $\begin{array}{l}\text { Lack of } \\
\text { awareness of this } \\
\text { practice and how } \\
\text { it can assist } \\
\text { incoming staff }\end{array}$ & $\begin{array}{l}\text { Poor } \\
\text { documentation of } \\
\text { real knowledge } \\
\text { in Bank systems }\end{array}$ & $\begin{array}{l}\text { Lack of } \\
\text { transmission } \\
\text { mechanisms }\end{array}$ & $\begin{array}{l}\text { No significant } \\
\text { efforts have } \\
\text { been made to } \\
\text { realize the } \\
\text { importance of } \\
\text { knowledge } \\
\text { sharing } \\
\text { systematically }\end{array}$ \\
\hline $\begin{array}{l}\text { Lack of } \\
\text { technology for } \\
\text { transmitting the } \\
\text { knowledge }\end{array}$ & $\begin{array}{l}\text { No fixed } \\
\text { template on how } \\
\text { to do knowledge } \\
\text { sharing }\end{array}$ & $\begin{array}{l}\text { Easy-to-access } \\
\text { online categories } \\
\text { of knowledge } \\
\text { would help make } \\
\text { it easier to find } \\
\text { relevant } \\
\text { information }\end{array}$ & $\begin{array}{l}\text { There is no } \\
\text { systematic } \\
\text { system of } \\
\text { gathering } \\
\text { knowledge }\end{array}$ & $\begin{array}{l}\text { Limited intrinsic } \\
\text { recognition, if at } \\
\text { all }\end{array}$ & $\begin{array}{l}\text { Individual desire } \\
\text { to seem } \\
\text { indispensable }\end{array}$ \\
\hline $\begin{array}{l}\text { Career/reward } \\
\text { incentives } \\
\text { insufficient }\end{array}$ & $\begin{array}{l}\text { Lacking contact } \\
\text { with a person to } \\
\text { handover when } \\
\text { you move to } \\
\text { another position }\end{array}$ & $\begin{array}{l}\text { Desire to possess } \\
\text { more knowledge } \\
\text { than others }\end{array}$ & $\begin{array}{l}\text { Constant reliance } \\
\text { on e-mail for } \\
\text { communication } \\
\text { across time } \\
\text { zones }\end{array}$ & $\begin{array}{l}\text { Lack of } \\
\text { awareness of } \\
\text { who else could } \\
\text { benefit from } \\
\text { your knowledge }\end{array}$ & $\begin{array}{l}\text { Intranet search is } \\
\text { poor, so it is } \\
\text { difficult to do a } \\
\text { basic review of } \\
\text { institutional } \\
\text { experience }\end{array}$ \\
\hline $\begin{array}{l}\text { Perception that } \\
\text { asking questions } \\
\text { reveals your lack } \\
\text { of knowledge }\end{array}$ & $\begin{array}{l}\text { Inappropriate } \\
\text { incentive } \\
\text { structure }\end{array}$ & $\begin{array}{l}\text { Lack of } \\
\text { individual } \\
\text { incentives }\end{array}$ & $\begin{array}{l}\text { Lack of } \\
\text { recognition }\end{array}$ & $\begin{array}{l}\text { Scarcity of } \\
\text { budget }\end{array}$ & $\begin{array}{l}\text { Weak } \\
\text { coordination } \\
\text { among } \\
\text { units/GPs }\end{array}$ \\
\hline $\begin{array}{l}\text { Lack of reporting } \\
\text { occurs }\end{array}$ & $\begin{array}{l}\text { Effort required } \\
\text { while rewards } \\
\text { are limited }\end{array}$ & $\begin{array}{l}\text { Lack of } \\
\text { frankness about } \\
\text { problems with } \\
\text { project }\end{array}$ & $\begin{array}{l}\text { Not part of the } \\
\text { normal } \\
\text { handover, } \\
\text { perceived as } \\
\text { bureaucratic } \\
\text { exercise }\end{array}$ & $\begin{array}{l}\text { WB not paying } \\
\text { attention to } \\
\text { transition plans }\end{array}$ & Time constraints \\
\hline $\begin{array}{l}\text { No requirement } \\
\text { to undertake the } \\
\text { task }\end{array}$ & $\begin{array}{l}\text { Individuals don't } \\
\text { feel ownership }\end{array}$ & $\begin{array}{l}\text { Lack of } \\
\text { examples of } \\
\text { good practice }\end{array}$ & $\begin{array}{l}\text { Lack of sharing } \\
\text { in work culture }\end{array}$ & $\begin{array}{l}\text { Not linked with } \\
\text { performance }\end{array}$ & $\begin{array}{l}\text { Problems in } \\
\text { country } \\
\text { communication } \\
\text { systems (i.e., } \\
\text { connectivity) }\end{array}$ \\
\hline Time zones & $\begin{array}{l}\text { Time availability } \\
\text { constrained }\end{array}$ & $\begin{array}{l}\text { Resource } \\
\text { availability }\end{array}$ & $\begin{array}{l}\text { Lack of support } \\
\text { staff }\end{array}$ & $\begin{array}{l}\text { Lack of support } \\
\text { platforms }\end{array}$ & $\begin{array}{l}\text { Client issues } \\
\text { interfere }\end{array}$ \\
\hline $\begin{array}{l}\text { Colleague } \\
\text { response levels } \\
\text { weak }\end{array}$ & $\begin{array}{l}\text { Available } \\
\text { communication } \\
\text { insufficient } \\
\text { (applications) }\end{array}$ & $\begin{array}{l}\text { No change in } \\
\text { culture toward } \\
\text { investments }\end{array}$ & $\begin{array}{l}\text { No cushioning } \\
\text { for overlap in } \\
\text { training } \\
\text { schedules }\end{array}$ & $\begin{array}{l}\text { No standard } \\
\text { approach }\end{array}$ & $\begin{array}{l}\text { No desire to } \\
\text { contribute }\end{array}$ \\
\hline $\begin{array}{l}\text { No equal } \\
\text { approach for } \\
\text { Country Office } \\
\text { and Headquarters } \\
\text { Staff }\end{array}$ & $\begin{array}{l}\text { No access from } \\
\text { newcomers to } \\
\text { existing systems }\end{array}$ & $\begin{array}{l}\text { Lack of } \\
\text { registration or } \\
\text { procedures }\end{array}$ & $\begin{array}{l}\text { No punishment } \\
\text { for not doing the } \\
\text { task }\end{array}$ & & \\
\hline
\end{tabular}


TABLE 15: Barriers by Com-B category

\begin{tabular}{|l|l|}
\hline Behavior Change Category & Count \\
\hline Automatic & 1 \\
\hline Reflective & 9 \\
\hline Social & 16 \\
\hline Physical & 26 \\
\hline
\end{tabular}

\section{Top Drivers for Top 10 List of Issues}

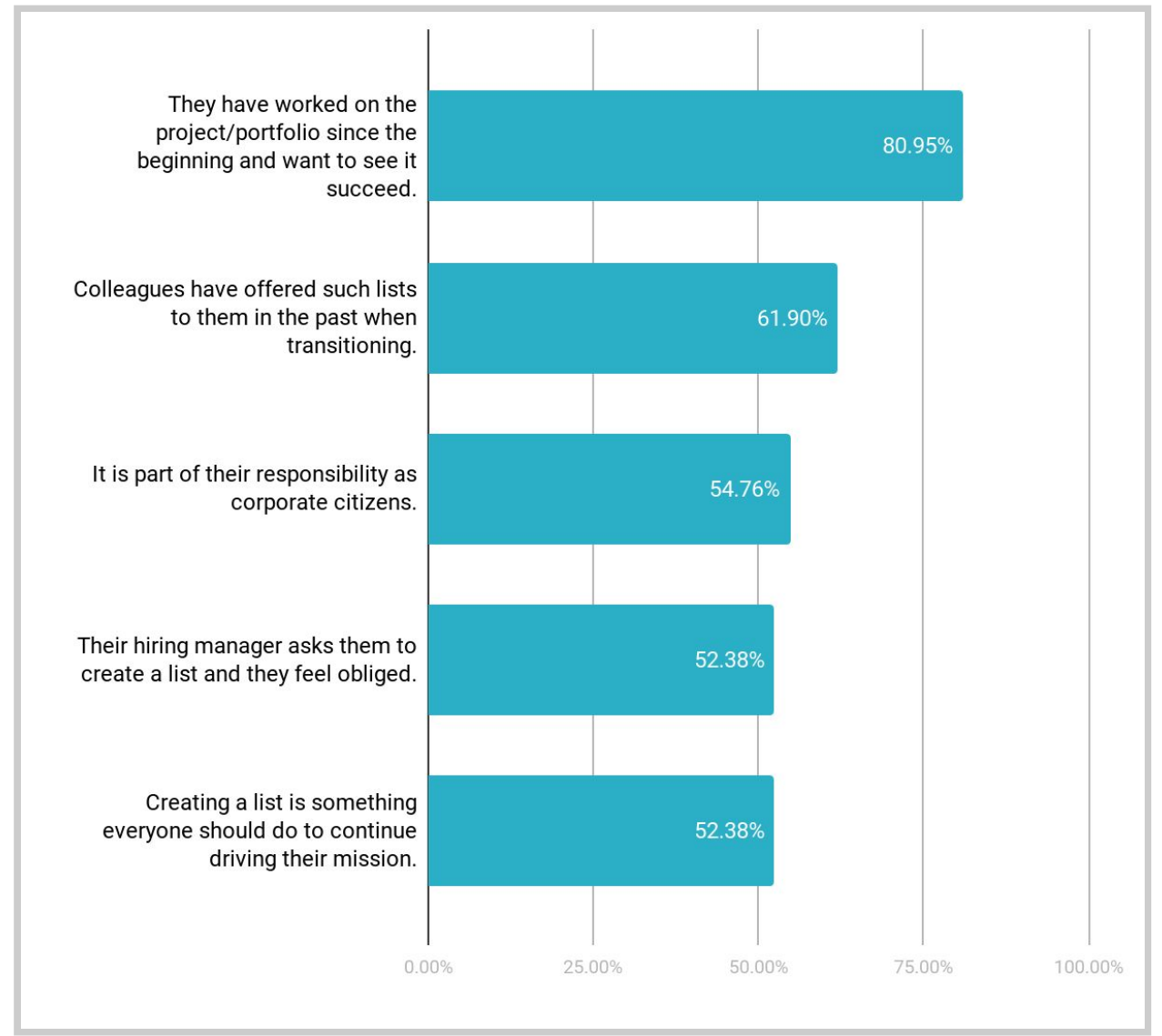

GRAPH 8: Top \% of respondents who agreed with statements related to drivers to Top 10 List of Issues. 
TABLE 16: Drivers for Top 10 List of issues as identified by respondents and their corresponding behavior change category based on the COM-B behavioral diagnostic framework

\begin{tabular}{|c|c|c|c|c|c|}
\hline $\begin{array}{l}\text { Attitudes about } \\
\text { knowledge as a } \\
\text { valuable input }\end{array}$ & $\begin{array}{l}\text { Make it a } \\
\text { management } \\
\text { requirement }\end{array}$ & $\begin{array}{l}\text { Written note } \\
\text { combined with } \\
\text { face-to-face } \\
\text { discussion to } \\
\text { elaborate on } \\
\text { nuances }\end{array}$ & $\begin{array}{l}\text { Have managers } \\
\text { give an annual } \\
\text { award for } \\
\text { knowledge } \\
\text { sharing }\end{array}$ & $\begin{array}{l}\text { Have managers } \\
\text { share widely } \\
\text { recognized } \\
\text { knowledge-shari } \\
\text { ng best practices }\end{array}$ & $\begin{array}{l}\text { Managers } \\
\text { emphasize how } \\
\text { important } \\
\text { knowledge } \\
\text { sharing is }\end{array}$ \\
\hline $\begin{array}{l}\text { Facilitate via tech: } \\
\text { pre-populate a } \\
10 \text {-issues list and } \\
\text { let TTL edit }\end{array}$ & $\begin{array}{l}\text { Give a } \\
\text { significant } \\
\text { monetary prize } \\
\text { for the VPU's } \\
\text { best knowledge } \\
\text { handovers }\end{array}$ & $\begin{array}{l}\text { Explore } \\
\text { publication } \\
\text { options of good } \\
\text { knowledge } \\
\text { transfer, with a } \\
\text { social media } \\
\text { support package } \\
\text { attached }\end{array}$ & $\begin{array}{l}\text { Career } \\
\text { recognition }\end{array}$ & $\begin{array}{l}\text { Personal } \\
\text { recognition }\end{array}$ & $\begin{array}{l}\text { Allocate time } \\
\text { for the activities }\end{array}$ \\
\hline $\begin{array}{l}\text { Desire to ensure } \\
\text { that future } \\
\text { knowledge work } \\
\text { is informed by and } \\
\text { builds on what has } \\
\text { already been done }\end{array}$ & $\begin{array}{l}\text { Desire to ensure } \\
\text { consistency and } \\
\text { continuity in } \\
\text { client messaging }\end{array}$ & $\begin{array}{l}\text { Give staff fewer } \\
\text { tasks that they } \\
\text { can spend more } \\
\text { time on }\end{array}$ & $\begin{array}{l}\text { Improve how all } \\
\text { types of } \\
\text { knowledge are } \\
\text { captured and } \\
\text { accessed }\end{array}$ & $\begin{array}{l}\text { Management } \\
\text { signaling of } \\
\text { openness to } \\
\text { questions and } \\
\text { open } \\
\text { nonjudgmental } \\
\text { discussion }\end{array}$ & $\begin{array}{l}\text { Better intranet } \\
\text { search function } \\
\text { to do basic } \\
\text { research on } \\
\text { available } \\
\text { institutional } \\
\text { activities }\end{array}$ \\
\hline $\begin{array}{l}\text { Periodic team } \\
\text { meetings to share } \\
\text { project updates }\end{array}$ & $\begin{array}{l}\text { Reduction in silo } \\
\text { mentality }\end{array}$ & $\begin{array}{l}\text { Psychological } \\
\text { value of } \\
\text { knowledge } \\
\text { contribution }\end{array}$ & $\begin{array}{l}\text { Sense of } \\
\text { ownership of } \\
\text { twin goals }\end{array}$ & $\begin{array}{l}\text { Youth members } \\
\text { are more prone } \\
\text { to engage }\end{array}$ & $\begin{array}{l}\text { Technology } \\
\text { advances }\end{array}$ \\
\hline $\begin{array}{l}\text { Monetary } \\
\text { incentives }\end{array}$ & $\begin{array}{l}\text { Visibility in } \\
\text { public or internal } \\
\text { events }\end{array}$ & Budget & $\begin{array}{l}\text { Automated } \\
\text { reporting }\end{array}$ & Collegiality & $\begin{array}{l}\text { Explicit demand } \\
\text { and recognition }\end{array}$ \\
\hline $\begin{array}{l}\text { Encourage staff } \\
\text { toward this } \\
\text { behavior } \\
\text { throughout their } \\
\text { career }\end{array}$ & $\begin{array}{l}\text { Have } \\
\text { management } \\
\text { lead by example } \\
\text { on this }\end{array}$ & $\begin{array}{l}\text { Have an exit } \\
\text { checklist }\end{array}$ & $\begin{array}{l}\text { Automated } \\
\text { handover } \\
\text { template }\end{array}$ & $\begin{array}{l}\text { System trigger to } \\
\text { show when } \\
\text { individuals are } \\
\text { ready for } \\
\text { transition }\end{array}$ & $\begin{array}{l}\text { Clearly set as } \\
\text { objective and } \\
\text { approved with } \\
\text { manager }\end{array}$ \\
\hline
\end{tabular}




\begin{tabular}{|l|l|l|l|l|l|}
\hline $\begin{array}{l}\text { Share best practice } \\
\text { examples to follow }\end{array}$ & $\begin{array}{l}\text { Request from } \\
\text { person taking } \\
\text { over task }\end{array}$ & $\begin{array}{l}\text { Individual } \\
\text { personality }\end{array}$ & $\begin{array}{l}\text { Rewards for } \\
\text { collaboration }\end{array}$ & $\begin{array}{l}\text { Create standard } \\
\text { format for this } \\
\text { knowledge } \\
\text { sharing }\end{array}$ & $\begin{array}{l}\text { Invest in } \\
\text { knowledge-shar } \\
\text { ing training for } \\
\text { staff }\end{array}$ \\
\hline Connectivity & Collaboration & Respect & Take interest & $\begin{array}{l}\text { Propose and } \\
\text { suggest }\end{array}$ & Take the lead \\
\hline Learning & Performance & $\begin{array}{l}\text { Growing } \\
\text { business }\end{array}$ & Recognition & Motivation & Resources \\
\hline
\end{tabular}

TABLE 17: Drivers by Com-B category

\begin{tabular}{|l|c|}
\hline Behavior Change Category & Count \\
\hline Automatic & 0 \\
\hline Reflective & 12 \\
\hline Social & 16 \\
\hline Physical & 26 \\
\hline
\end{tabular}




\section{KDB 4-Sharing Short Relevant Punchy Pieces}

\section{Barriers to Short Relevant Punchy Pieces}

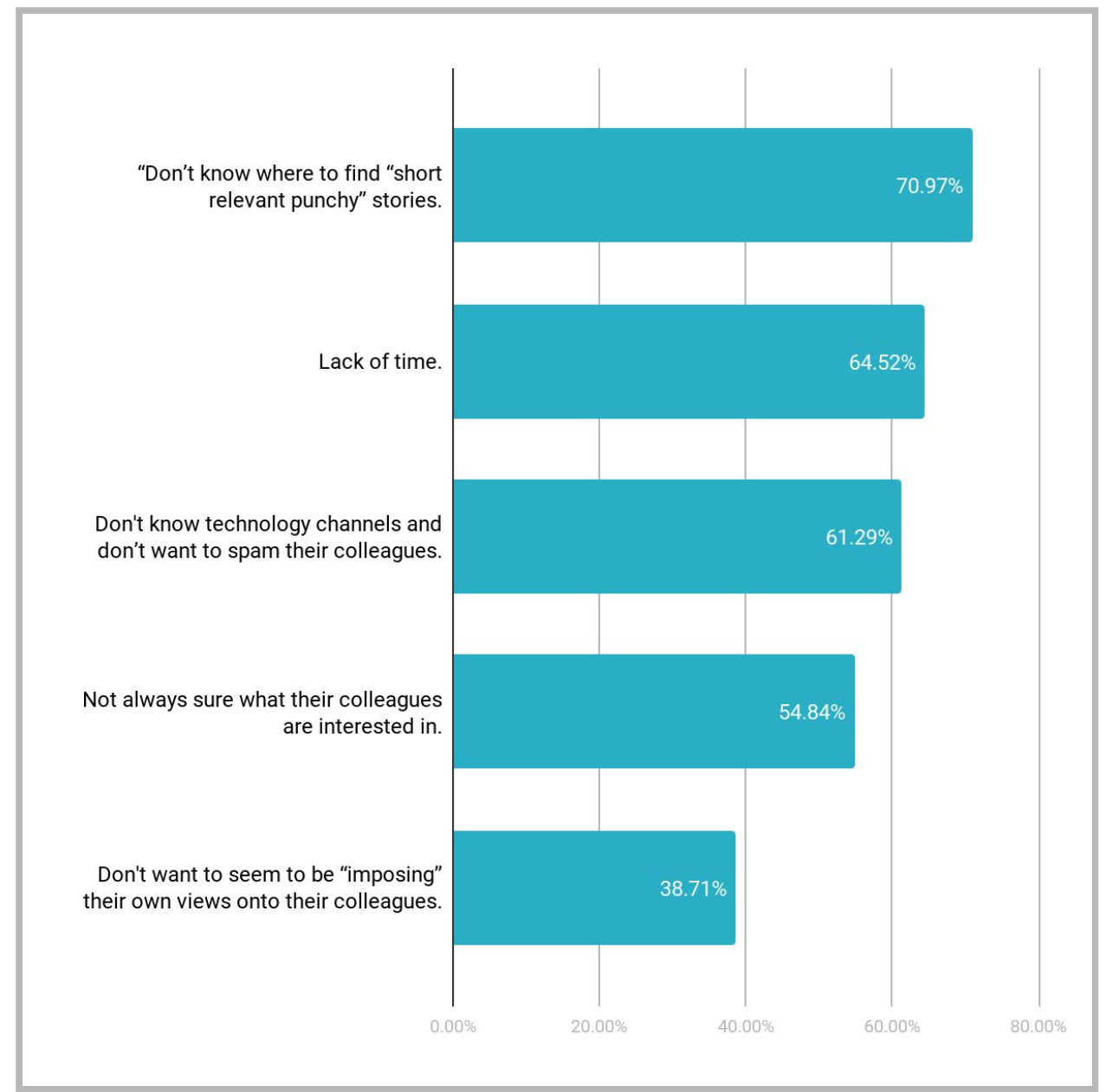

GRAPH 9: Top \% of respondents who agreed with statements relating to barriers to Sharing Short Relevant Punchy Pieces 
TABLE 18: Barriers to Top 10 List of issues identified by respondents and their corresponding behavior change category based on the COM-B behavioral diagnostic framework

\begin{tabular}{|c|c|c|c|c|c|}
\hline $\begin{array}{l}\text { Managers don't } \\
\text { recognize value }\end{array}$ & $\begin{array}{l}\text { Normal systems } \\
\text { don't support it }\end{array}$ & $\begin{array}{l}\text { Giving away the } \\
\text { whole recipe } \\
\text { can make your } \\
\text { competitors } \\
\text { stronger }\end{array}$ & $\begin{array}{l}\text { Senior staff take } \\
\text { the credit for } \\
\text { inputs and } \\
\text { intellectual } \\
\text { contributions of } \\
\text { junior staff }\end{array}$ & $\begin{array}{l}\text { Individual } \\
\text { perception that } \\
\text { people can learn } \\
\text { about the } \\
\text { project without } \\
\text { support and } \\
\text { others should be } \\
\text { able to as well }\end{array}$ & $\begin{array}{l}\text { Wanting to be } \\
\text { recognized as } \\
\text { the only } \\
\text { expert/specialist } \\
\text { on a project or } \\
\text { in a field }\end{array}$ \\
\hline $\begin{array}{l}\text { No incentives } \\
\text { offered }\end{array}$ & $\begin{array}{l}\text { Lack of } \\
\text { knowledge-sharin } \\
\text { g culture }\end{array}$ & $\begin{array}{l}\text { No personal } \\
\text { gain }\end{array}$ & $\begin{array}{l}\text { Keeping the } \\
\text { ownership of } \\
\text { knowledge }\end{array}$ & $\begin{array}{l}\text { Time barriers } \\
\text { due to poor } \\
\text { planning for } \\
\text { transitioning } \\
\text { staff }\end{array}$ & $\begin{array}{l}\text { One-individual, } \\
\text { one-project } \\
\text { mindset }\end{array}$ \\
\hline $\begin{array}{l}\text { Not having } \\
\text { dedicated time } \\
\text { to support } \\
\text { collaboration }\end{array}$ & $\begin{array}{l}\text { Misaligned } \\
\text { incentives }\end{array}$ & $\begin{array}{l}\text { Lack of } \\
\text { motivation }\end{array}$ & $\begin{array}{l}\text { Lack of } \\
\text { requirement }\end{array}$ & $\begin{array}{l}\text { Poor role } \\
\text { modeling }\end{array}$ & $\begin{array}{l}\text { Individual } \\
\text { recognition }\end{array}$ \\
\hline $\begin{array}{l}\text { Lacks } \\
\text { authenticity - of } \\
\text { ten reads like } \\
\text { project team and } \\
\text { Bank } \\
\text { propaganda }\end{array}$ & $\begin{array}{l}\text { Nothing critical is } \\
\text { written/shared }\end{array}$ & $\begin{array}{l}\text { Difficulty in } \\
\text { using } \\
\text { technology } \\
\text { resources }\end{array}$ & $\begin{array}{l}\text { Managers support } \\
\text { knowledge } \\
\text { sharing only at } \\
\text { the declarative } \\
\text { level }\end{array}$ & $\begin{array}{l}\text { No punishment } \\
\text { for NOT } \\
\text { sharing }\end{array}$ & $\begin{array}{l}\text { Lack of time, } \\
\text { resources, and } \\
\text { incentives }\end{array}$ \\
\hline $\begin{array}{l}\text { High amounts of } \\
\text { TTL turn around }\end{array}$ & $\begin{array}{l}\text { No clear structure } \\
\text { for knowledge } \\
\text { sharing in GPs }\end{array}$ & $\begin{array}{l}\text { Don't have the } \\
\text { necessary skills } \\
\text { to communicate } \\
\text { short, clear, } \\
\text { crisp messages }\end{array}$ & $\begin{array}{l}\text { No coordinated } \\
\text { knowledge-sharin } \\
\text { g activities and } \\
\text { overlapping } \\
\text { activities }\end{array}$ & Competitiveness & $\begin{array}{l}\text { Staff are } \\
\text { pressured with } \\
\text { other priorities } \\
\text { and deliverables }\end{array}$ \\
\hline $\begin{array}{l}\text { Inward looking } \\
\text { management } \\
\text { and rewards } \\
\text { structure }\end{array}$ & $\begin{array}{l}\text { Lack of explicit } \\
\text { monetary rewards }\end{array}$ & $\begin{array}{l}\text { GP structured as } \\
\text { silos }\end{array}$ & Stress & & \\
\hline
\end{tabular}

\section{TABLE 19: Barriers by Com-B category}

\begin{tabular}{|l|l|}
\hline Behavior Change Category & Count \\
\hline Automatic & 1 \\
\hline Reflective & 7 \\
\hline Social & 11 \\
\hline Physical & 14 \\
\hline Psychological & 1 \\
\hline
\end{tabular}




\section{Drivers to Short Relevant Punchy Pieces}

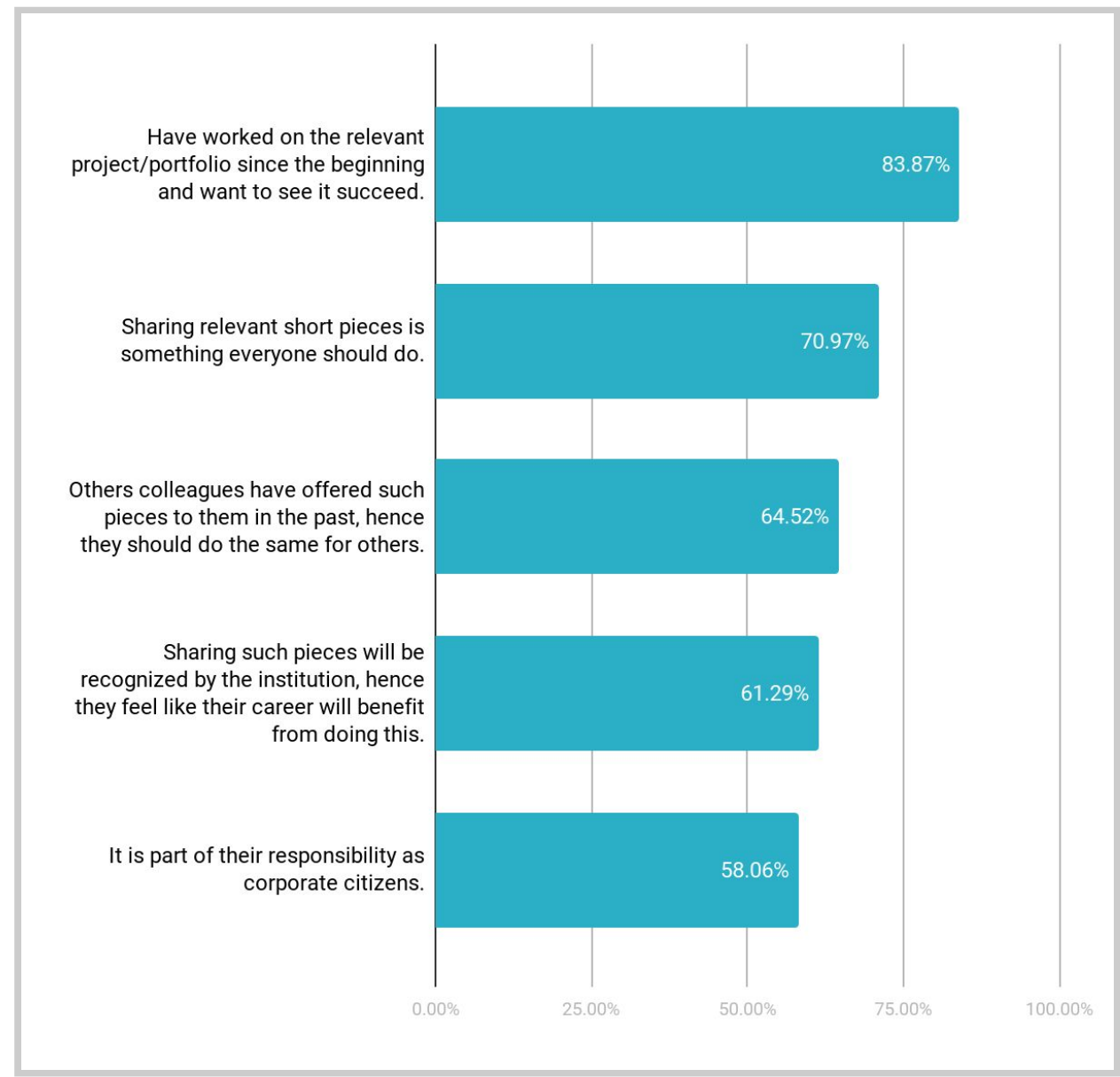

GRAPH 10: Top \% of respondents who agreed with statements relating to drivers to Sharing Short Relevant Punchy Pieces

TABLE 20: Drivers for Top 10 issues identified by respondents and their corresponding behavior change category based on the COM-B behavioral diagnostic framework

\begin{tabular}{l|l|l|l|l|l}
$\begin{array}{l}\text { Helps your } \\
\text { reputation as a } \\
\text { valued staff } \\
\text { member }\end{array}$ & $\begin{array}{l}\text { Sense of } \\
\text { commitment to } \\
\text { seeing the } \\
\text { project succeed }\end{array}$ & $\begin{array}{l}\text { Getting the } \\
\text { contribution } \\
\text { published }\end{array}$ & $\begin{array}{l}\text { Making it a } \\
\text { work-cultural } \\
\text { value }\end{array}$ & $\begin{array}{l}\text { Recognition } \\
\text { (either monetary } \\
\text { or performance) }\end{array}$ & $\begin{array}{l}\text { Goodwill among } \\
\text { peers and } \\
\text { managers }\end{array}$ \\
\hline $\begin{array}{l}\text { Encouragement } \\
\text { by managers }\end{array}$ & $\begin{array}{l}\text { Others sharing it } \\
\text { on a regular } \\
\text { basis }\end{array}$ & $\begin{array}{l}\text { The need to } \\
\text { succinctly } \\
\text { summarize }\end{array}$ & $\begin{array}{l}\text { Make the team } \\
\text { efforts more } \\
\text { known }\end{array}$ & $\begin{array}{l}\text { Provide } \\
\text { professional } \\
\text { incentives for } \\
\text { sharing }\end{array}$ & $\begin{array}{l}\text { Acknowledgeme } \\
\text { nt of } \\
\text { contributions } \\
\text { other than a } \\
\text { project or the }\end{array}$ \\
\hline $\begin{array}{l}\text { Accountability } \\
\text { of projects after } \\
\text { staff has } \\
\text { transitioned out }\end{array}$ & $\begin{array}{l}\text { Team-based } \\
\text { project mindset }\end{array}$ & $\begin{array}{l}\text { More salient } \\
\text { internal } \\
\text { recognition of } \\
\text { knowledge } \\
\text { sharing efforts }\end{array}$ & Incentives & $\begin{array}{l}\text { Usefulness of the } \\
\text { activity is } \\
\text { communicated }\end{array}$ & \begin{tabular}{l} 
Requirement \\
\hline
\end{tabular}
\end{tabular}




\begin{tabular}{|c|c|c|c|c|c|}
\hline $\begin{array}{l}\text { Ease of } \\
\text { technology }\end{array}$ & $\begin{array}{l}\text { Incentives (real } \\
\text { not nominal) }\end{array}$ & $\begin{array}{l}\text { Institutional } \\
\text { recognition/ } \\
\text { reward }\end{array}$ & $\begin{array}{l}\text { Define } \\
\text { measurable } \\
\text { "targets," make } \\
\text { people } \\
\text { accountable and } \\
\text { track them }\end{array}$ & $\begin{array}{l}\text { Develop and } \\
\text { regularly } \\
\text { publish } \\
\text { knowledge-shari } \\
\text { ng "scorecard" } \\
\text { to track how } \\
\text { staff are doing } \\
\text { this }\end{array}$ & $\begin{array}{l}\text { Provide } \\
\text { incentives like } \\
\text { participation in } \\
\text { conferences/ } \\
\text { paper in journals, } \\
\text { etc. }\end{array}$ \\
\hline $\begin{array}{l}\text { Make it part of } \\
\text { OPE process }\end{array}$ & $\begin{array}{l}\text { Co-creation } \\
\text { retreats }\end{array}$ & $\begin{array}{l}\text { Evaluation of } \\
\text { best practice } \\
\text { tied up with } \\
\text { incentives }\end{array}$ & $\begin{array}{l}\text { Include as an } \\
\text { agenda once a } \\
\text { month in staff } \\
\text { meeting }\end{array}$ & $\begin{array}{l}\text { Career } \\
\text { development }\end{array}$ & $\begin{array}{l}\text { Demonstrative } \\
\text { effect by } \\
\text { managers }\end{array}$ \\
\hline $\begin{array}{l}\text { Desire for } \\
\text { technical } \\
\text { expertise } \\
\text { recognition }\end{array}$ & $\begin{array}{l}\text { Sense of } \\
\text { ownership }\end{array}$ & $\begin{array}{l}\text { Include as an } \\
\text { agenda once a } \\
\text { month in staff } \\
\text { meeting }\end{array}$ & $\begin{array}{l}\text { Make } \\
\text { knowledge } \\
\text { sharing and } \\
\text { dissemination } \\
\text { explicit OPE } \\
\text { targets }\end{array}$ & $\begin{array}{l}\text { Leadership roles } \\
\text { linked to } \\
\text { knowledge } \\
\text { sharing }\end{array}$ & \\
\hline
\end{tabular}

TABLE 21: Drivers by Com-B category

\begin{tabular}{|l|l|}
\hline Behavior Change Category & Count \\
\hline Automatic & 0 \\
\hline Reflective & 2 \\
\hline Social & 3 \\
\hline Physical & 7 \\
\hline
\end{tabular}




\section{KDB 5-Proactive Sign-ups for Trainings Unrelated to ToR}

\section{Barriers to Sign-ups}

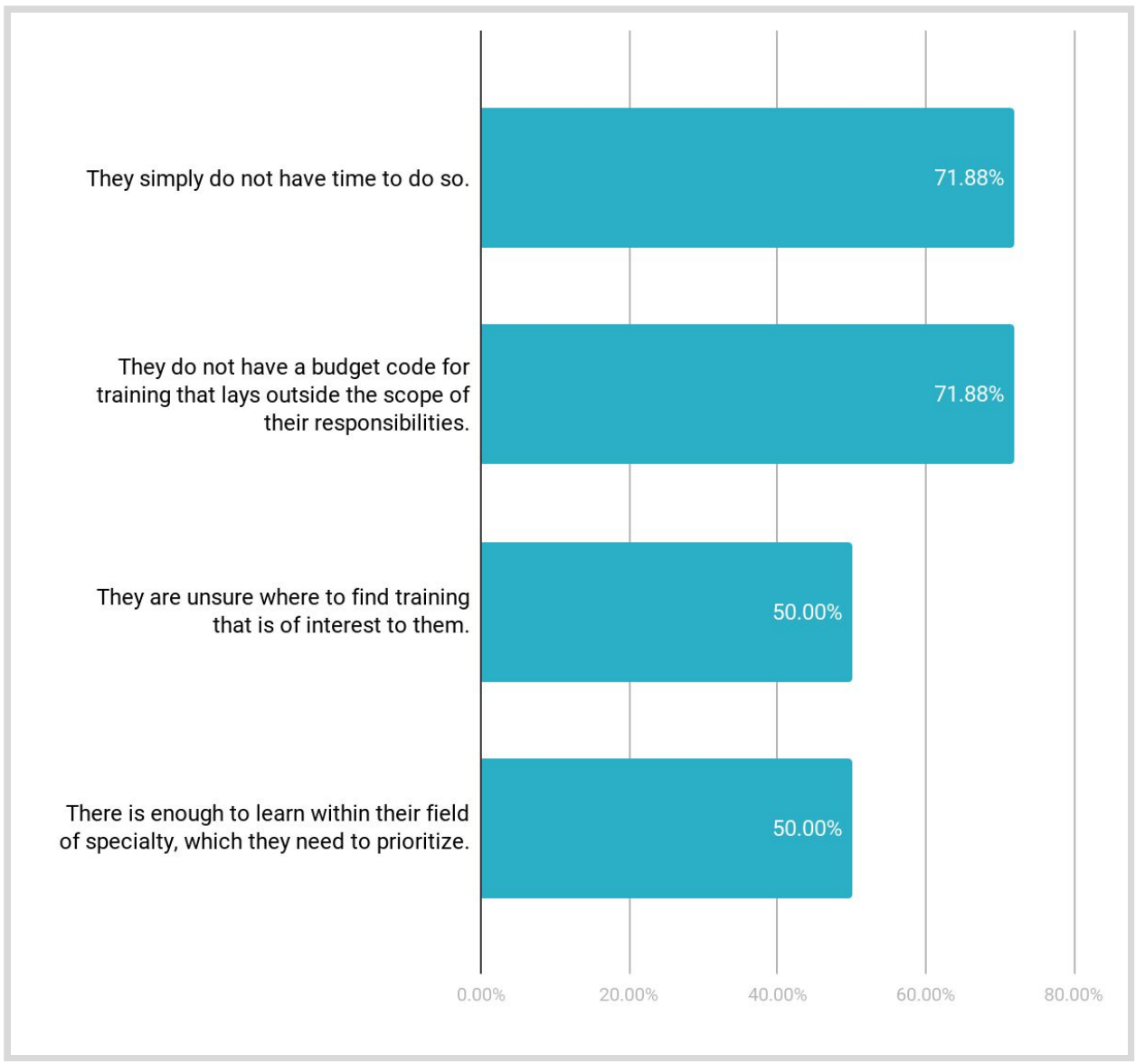

GRAPH 11: Top \% of respondents who agreed with statements related to barriers to Proactive Sign-ups for Trainings Unrelated to ToR included

TABLE 22: Barriers to proactive sign-ups for training unrelated to ToR identified by respondents and their corresponding behavior change category based on the COM-B behavioral diagnostic framework

\begin{tabular}{l|l|l|l|l|l}
$\begin{array}{l}\text { Lack of } \\
\text { knowledge- } \\
\text { sharing } \\
\text { tradition/culture }\end{array}$ & $\begin{array}{l}\text { Insufficient time } \\
\text { and having too } \\
\text { many other } \\
\text { responsibilities }\end{array}$ & $\begin{array}{l}\text { Lack of } \\
\text { technological } \\
\text { facilities to } \\
\text { support } \\
\text { knowledge } \\
\text { sharing }\end{array}$ & $\begin{array}{l}\text { Limited human } \\
\text { resource } \\
\text { opportunities }\end{array}$ & $\begin{array}{l}\text { Too much focus } \\
\text { on continuous } \\
\text { change (as } \\
\text { opposed to } \\
\text { building staff } \\
\text { capacity) }\end{array}$ & $\begin{array}{l}\text { Lack of } \\
\text { leadership from } \\
\text { the top }\end{array}$ \\
\hline $\begin{array}{l}\text { Trainings based } \\
\text { in field }\end{array}$ & $\begin{array}{l}\text { Lack } \\
\text { presentation } \\
\text { skills }\end{array}$ & $\begin{array}{l}\text { Strategic HR } \\
\text { planning } \\
\text { exercise (many } \\
\text { experienced staff } \\
\text { leaving) }\end{array}$ & $\begin{array}{l}\text { Incentive } \\
\text { structure does } \\
\text { not encourage } \\
\text { knowledge } \\
\text { sharing }\end{array}$ & $\begin{array}{l}\text { Management } \\
\text { incentivizes } \\
\text { completing } \\
\text { products not } \\
\text { dissemination }\end{array}$ & Silos \\
\hline
\end{tabular}




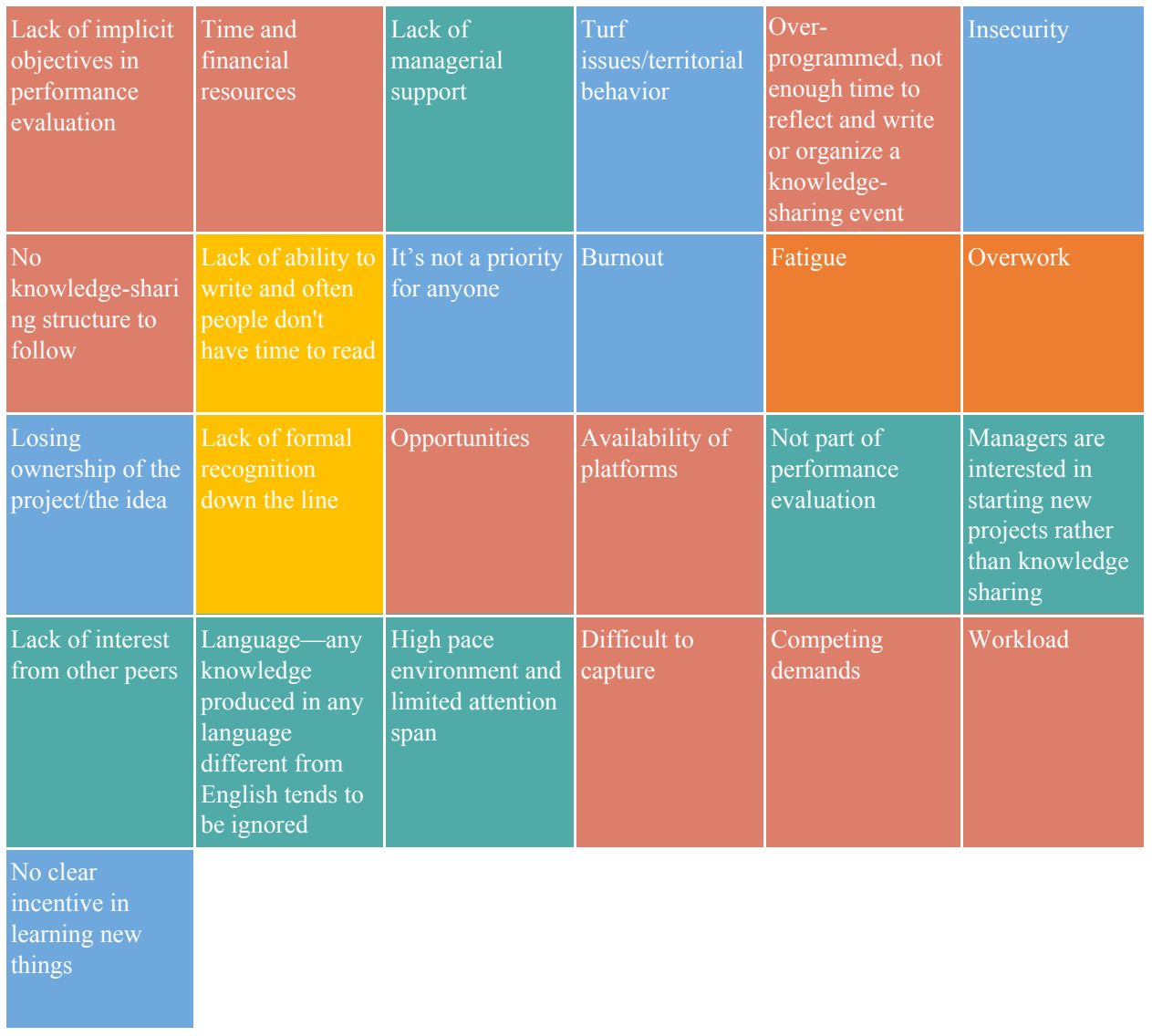

TABLE 23: Barriers by Com-B category

\begin{tabular}{|l|l|}
\hline Behavior Change Category & Count \\
\hline Automatic & 2 \\
\hline Reflective & 6 \\
\hline Social & 13 \\
\hline Physical & 14 \\
\hline Psychological & 2 \\
\hline
\end{tabular}




\section{Top Drivers for Proactive Sign-ups for Trainings Unrelated to ToR}

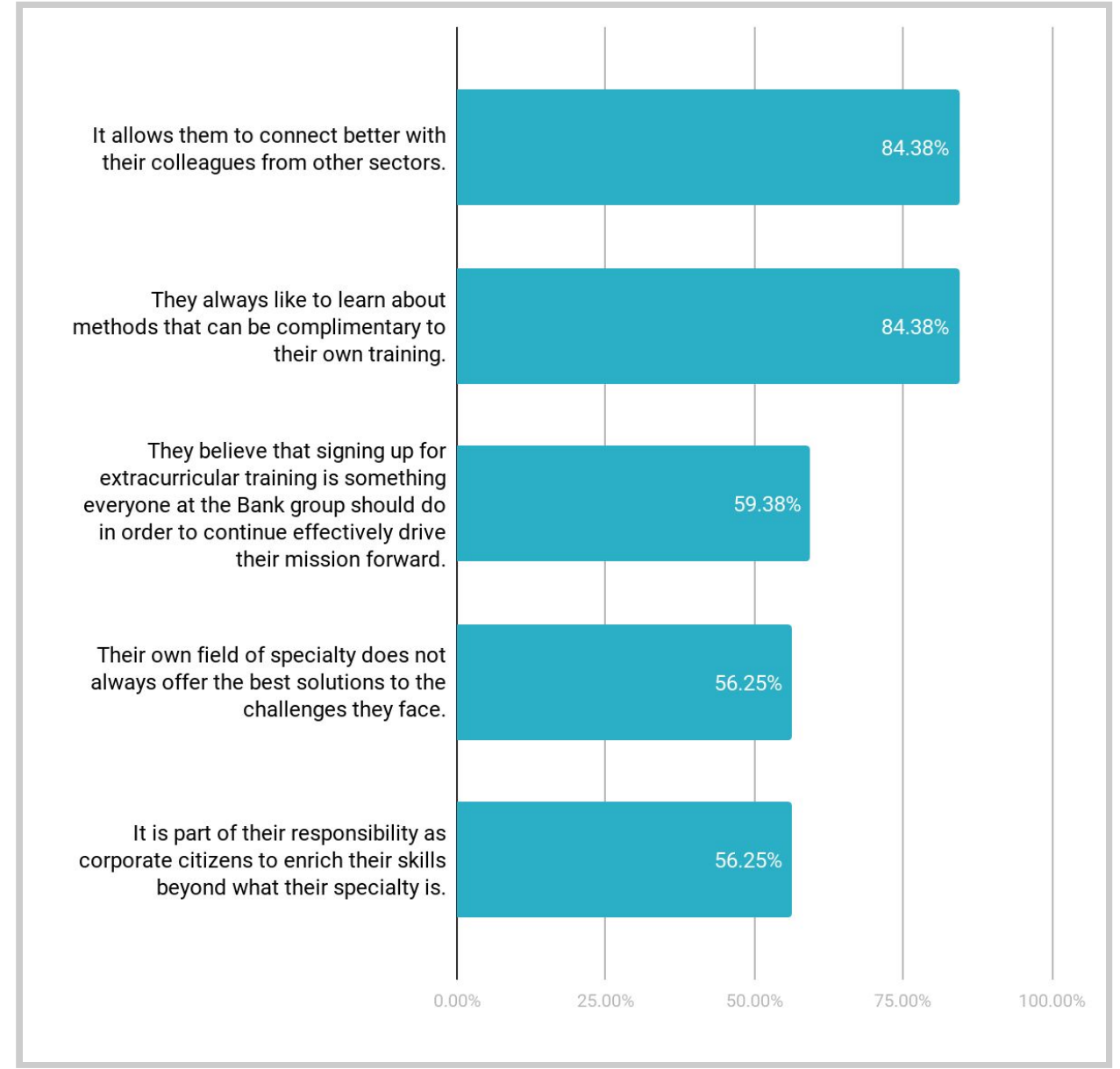

GRAPH 12: Top \% of respondents who agreed with statements related to drivers to Proactive Sign-ups for Trainings Unrelated to ToR included

TABLE 24: Drivers to proactive sign-ups for training unrelated to ToR identified by respondents and their corresponding behavior change category based on the COM-B behavioral diagnostic framework

\begin{tabular}{l|l|l|l|l|l}
$\begin{array}{l}\text { Recognition by } \\
\text { management }\end{array}$ & $\begin{array}{l}\text { Recognition for } \\
\text { knowledge } \\
\text { sharing and } \\
\text { applying lessons } \\
\text { learned from } \\
\text { other projects }\end{array}$ & $\begin{array}{l}\text { Providing } \\
\text { opportunity (e.g., } \\
\text { brown bags) }\end{array}$ & $\begin{array}{l}\text { Should be part of } \\
\text { OPE/PEP of } \\
\text { project manager } \\
\text { level and higher } \\
\text { staff }\end{array}$ & $\begin{array}{l}\text { Resources to } \\
\text { screen and } \\
\text { systematize } \\
\text { knowledge in an } \\
\text { easily accessible } \\
\text { way }\end{array}$ & $\begin{array}{l}\text { Rotate } \\
\text { experienced staff } \\
\text { through }\end{array}$ \\
$\begin{array}{l}\text { knowledge unit } \\
\text { (DA) }\end{array}$ \\
\hline New learning \\
opportunities & $\begin{array}{l}\text { Part of } \\
\text { professional } \\
\text { profile }\end{array}$ & $\begin{array}{l}\text { Strong } \\
\text { commitments } \\
\text { from staff }\end{array}$ & $\begin{array}{l}\text { Interest to bring } \\
\text { innovation to } \\
\text { projects }\end{array}$ & $\begin{array}{l}\text { Interest to } \\
\text { improve design } \\
\text { by learning from } \\
\text { others }\end{array}$ & $\begin{array}{l}\text { Desire to } \\
\text { collaborate }\end{array}$ \\
\hline
\end{tabular}




\begin{tabular}{|c|c|c|c|c|c|}
\hline $\begin{array}{l}\text { Own belief that } \\
\text { one benefits } \\
\text { from sharing }\end{array}$ & $\begin{array}{l}\text { Understanding } \\
\text { of the value } \\
\text { added to the } \\
\text { person's } \\
\text { reputation }\end{array}$ & $\begin{array}{l}\text { Include sharing } \\
\text { of knowledge in } \\
\text { performance } \\
\text { evaluation }\end{array}$ & $\begin{array}{l}\text { An app or some } \\
\text { digital platform } \\
\text { that allows staff } \\
\text { to share quickly }\end{array}$ & $\begin{array}{l}\text { Clear metrics to } \\
\text { measure } \\
\text { knowledge } \\
\text { sharing }\end{array}$ & $\begin{array}{l}\text { Make it easy for } \\
\text { people to do it } \\
\text { and find it hard } \\
\text { to say no when } \\
\text { asked }\end{array}$ \\
\hline $\begin{array}{l}\text { Establish } \\
\text { dedicated unit of } \\
\text { consultants to do } \\
\text { this }\end{array}$ & $\begin{array}{l}\text { Stop repeating } \\
\text { what has never } \\
\text { worked in } \\
\text { decades }\end{array}$ & More time & $\begin{array}{l}\text { Genuine } \\
\text { leadership }\end{array}$ & $\begin{array}{l}\text { Behavioral } \\
\text { changes from } \\
\text { the top }\end{array}$ & $\begin{array}{l}\text { Encouraging } \\
\text { behavior of } \\
\text { sharing and } \\
\text { accepting } \\
\text { mistakes as part } \\
\text { of the learning } \\
\text { process }\end{array}$ \\
\hline $\begin{array}{l}\text { Success should } \\
\text { be replicated }\end{array}$ & $\begin{array}{l}\text { A platform of } \\
\text { exchanges } \\
\text { where you also } \\
\text { gain from } \\
\text { others' } \\
\text { knowledge }\end{array}$ & $\begin{array}{l}\text { A strong } \\
\text { motivator to } \\
\text { pass the } \\
\text { knowledge to } \\
\text { others and in } \\
\text { the process } \\
\text { improve on it }\end{array}$ & Visibility & Ownership & Ease of access \\
\hline $\begin{array}{l}\text { Official } \\
\text { communication } \\
\text { to all staff on } \\
\text { the need to } \\
\text { share } \\
\text { data/informatio } \\
\text { n/knowledge } \\
\text { widely }\end{array}$ & $\begin{array}{l}\text { Encourage } \\
\text { sharing } \\
\text { formally } \\
\text { (e-mails) or } \\
\text { informally } \\
\text { (WhatsApp). }\end{array}$ & $\begin{array}{l}\text { Should be part } \\
\text { of performance } \\
\text { target }\end{array}$ & $\begin{array}{l}\text { Rewarding } \\
\text { collaboration }\end{array}$ & $\begin{array}{l}\text { Promoting } \\
\text { Co-TTLship }\end{array}$ & $\begin{array}{l}\text { Stressing on } \\
\text { corporate } \\
\text { mandate for } \\
\text { knowledge } \\
\text { production and } \\
\text { sharing }\end{array}$ \\
\hline Incentives & $\begin{array}{l}\text { Relevance and } \\
\text { impact on } \\
\text { one's own } \\
\text { career }\end{array}$ & $\begin{array}{l}\text { Make it part of } \\
\text { the culture }\end{array}$ & $\begin{array}{l}\text { Innovate and } \\
\text { make } \\
\text { knowledge } \\
\text { sharing easier }\end{array}$ & & \\
\hline
\end{tabular}

TABLE 25: Drivers by Com-B category

\begin{tabular}{|l|l|}
\hline Behavior Change Category & Count \\
\hline Automatic & 0 \\
\hline Reflective & 9 \\
\hline Social & 15 \\
\hline Physical & 16 \\
\hline
\end{tabular}




\section{Appendix VI: Survey Results-Descriptive Statistics}

TABLE 26: Knowledge sharing overall

\begin{tabular}{|c|c|c|c|}
\hline Behavior Statement & Mean & $\begin{array}{l}\text { Standard } \\
\text { deviation }\end{array}$ & $\%$ Agree \\
\hline I often see other WB staff engage in this behavior. & 3.883 & 1.582 & $39.84 \%$ \\
\hline $\begin{array}{l}\text { I think other WB staff would feel a sense of } \\
\text { accomplishment if they were to engage in this } \\
\text { behavior. }\end{array}$ & 5.238 & 1.281 & $74.61 \%$ \\
\hline $\begin{array}{l}\text { I think that a sense of ownership a person has toward } \\
\text { a project incentivizes them to engage in this behavior. }\end{array}$ & 5.648 & 1.237 & $82.42 \%$ \\
\hline $\begin{array}{l}\text { I think the current technological systems in place } \\
\text { hinder other WB staff from engaging in this behavior. }\end{array}$ & 4.020 & 1.494 & $38.28 \%$ \\
\hline $\begin{array}{l}\text { I think that those who had a positive and useful } \\
\text { knowledge transfer experience in the past are more } \\
\text { likely to engage in this behavior. }\end{array}$ & 5.750 & 1.088 & $87.50 \%$ \\
\hline $\begin{array}{l}\text { I think other WB staff would be more likely to engage } \\
\text { in this behavior if the output would be more visible } \\
\text { (i.e., seen and recognized by a larger number of } \\
\text { colleagues). }\end{array}$ & 5.484 & 1.262 & $80.86 \%$ \\
\hline $\begin{array}{l}\text { I think other WB staff would be more likely to engage } \\
\text { in this behavior if their manager provided them with } \\
\text { sufficient time. }\end{array}$ & 5.492 & 1.296 & $80.08 \%$ \\
\hline $\begin{array}{l}\text { I think other WB staff would be more likely to engage } \\
\text { in this behavior if it were part of their performance } \\
\text { evaluation criteria. }\end{array}$ & 5.609 & 1.276 & $82.81 \%$ \\
\hline $\begin{array}{l}\text { I think other WB staff would be more likely to engage } \\
\text { in this behavior if others around them engaged in it. }\end{array}$ & 5.531 & 0.994 & $85.55 \%$ \\
\hline $\begin{array}{l}\text { I think other WB staff would be more likely to engage } \\
\text { in this behavior if it were tied to extrinsic rewards } \\
\text { (performance bonus and other monetary rewards). }\end{array}$ & 4.930 & 1.507 & $61.72 \%$ \\
\hline $\begin{array}{l}\text { I think other WB staff would be more likely to engage } \\
\text { in this behavior if it were tied to intrinsic rewards } \\
\text { (e.g., sense of accomplishment, social recognition, } \\
\text { sense of ownership, etc.). }\end{array}$ & 5.477 & 1.120 & $82.42 \%$ \\
\hline $\begin{array}{l}\text { Sharing knowledge about a project is important to } \\
\text { other WB staff because when they have worked on the } \\
\text { project from the beginning they want to see it } \\
\text { succeed, even if they are moving on to another role. }\end{array}$ & 5.852 & 0.991 & $89.45 \%$ \\
\hline
\end{tabular}




\begin{tabular}{|l|l|l|l|}
\hline $\begin{array}{l}\text { Sharing knowledge about one's project is motivated } \\
\text { by the fact that other World Bank colleagues share } \\
\text { their project knowledge as well. }\end{array}$ & 4.867 & 1.325 & $66.02 \%$ \\
\hline $\begin{array}{l}\text { Sharing knowledge about one's project with other } \\
\text { World Bank colleagues is important, even if other } \\
\text { colleagues do not share their knowledge. }\end{array}$ & 5.781 & 0.978 & $89.45 \%$ \\
\hline $\begin{array}{l}\text { Sharing knowledge is important, but one has to } \\
\text { prioritize other tasks given the limited amount of time } \\
\text { and budgets available to dedicate on their own } \\
\text { projects. }\end{array}$ & 5.156 & 1.599 & $73.83 \%$ \\
\hline $\begin{array}{l}\text { Knowledge sharing at the World Bank is a challenge } \\
\text { even when sufficient time and budgets are provided. }\end{array}$ & 4.719 & 1.566 & $63.28 \%$ \\
\hline $\begin{array}{l}\text { Sharing knowledge with colleagues does not benefit } \\
\text { one personally. }\end{array}$ & 2.918 & 1.452 & $17.58 \%$ \\
\hline $\begin{array}{l}\text { A career at the Bank is defined through the knowledge } \\
\text { one possesses. Giving that knowledge away by } \\
\text { sharing with other WB staff does not necessarily align } \\
\text { with one's own career interests. }\end{array}$ & 2.832 & 1.717 & $19.92 \%$ \\
\hline $\begin{array}{l}\text { The reality here is that everyone wants to win projects } \\
\text { for their own unit. There is no strong incentive in } \\
\text { sharing knowledge with other units. }\end{array}$ & 4.063 & 1.763 & $46.48 \%$ \\
\hline
\end{tabular}

TABLE 27: KDB1 handover package rating data

\begin{tabular}{|l|l|l|}
\hline Behavior Statement & Mean & \% Agree \\
\hline $\begin{array}{l}\text { I often see other WB staff at the Bank engage in this } \\
\text { behavior. }\end{array}$ & 3.883 & $39.84 \%$ \\
\hline $\begin{array}{l}\text { I think other WB staff would feel a sense of } \\
\text { accomplishment if they were to engage in this } \\
\text { behavior. }\end{array}$ & 5.238 & $74.61 \%$ \\
\hline $\begin{array}{l}\text { I think that a sense of ownership a person has toward } \\
\text { a project incentivizes them to engage in this behavior. }\end{array}$ & 5.648 & $82.42 \%$ \\
\hline $\begin{array}{l}\text { I think the current technological systems in place } \\
\text { hinder other WB staff from engaging in this behavior. }\end{array}$ & 4.020 & $38.28 \%$ \\
\hline $\begin{array}{l}\text { I think that those who had a positive and useful } \\
\text { knowledge transfer experience in the past are more } \\
\text { likely to engage in this behavior. }\end{array}$ & 5.750 & $87.50 \%$ \\
\hline
\end{tabular}




\begin{tabular}{|c|c|c|}
\hline $\begin{array}{l}\text { I think other WB staff would be more likely to engage } \\
\text { in this behavior if the output would be more visible } \\
\text { (i.e., seen and recognized by a larger number of } \\
\text { colleagues). }\end{array}$ & 5.484 & $80.86 \%$ \\
\hline $\begin{array}{l}\text { I think other WB staff would be more likely to engage } \\
\text { in this behavior if their manager provided them with } \\
\text { sufficient time. }\end{array}$ & 5.492 & $80.08 \%$ \\
\hline $\begin{array}{l}\text { I think other WB staff would be more likely to engage } \\
\text { in this behavior if it were part of their performance } \\
\text { evaluation criteria. }\end{array}$ & 5.609 & $82.81 \%$ \\
\hline $\begin{array}{l}\text { I think other WB staff would be more likely to engage } \\
\text { in this behavior if others around them engaged in it. }\end{array}$ & 5.531 & $85.55 \%$ \\
\hline $\begin{array}{l}\text { I think other WB staff would be more likely to engage } \\
\text { in this behavior if it were tied to extrinsic rewards } \\
\text { (performance bonus and other monetary rewards). }\end{array}$ & 4.930 & $61.72 \%$ \\
\hline $\begin{array}{l}\text { I think other WB staff would be more likely to engage } \\
\text { in this behavior if it were tied to intrinsic rewards } \\
\text { (e.g., sense of accomplishment, social recognition, } \\
\text { sense of ownership, etc.). }\end{array}$ & 5.477 & $82.42 \%$ \\
\hline $\begin{array}{l}\text { Sharing knowledge about a project is important to } \\
\text { other WB staff because when they have worked on } \\
\text { the project from the beginning they want to see it } \\
\text { succeed, even if they are moving on to another role. }\end{array}$ & 5.852 & $89.45 \%$ \\
\hline $\begin{array}{l}\text { Sharing knowledge about one's project is motivated } \\
\text { by the fact that other World Bank colleagues share } \\
\text { their project knowledge as well. }\end{array}$ & 4.867 & $66.02 \%$ \\
\hline $\begin{array}{l}\text { Sharing knowledge about one's project with other } \\
\text { World Bank colleagues is important, even if other } \\
\text { colleagues do not share their knowledge. }\end{array}$ & 5.781 & $89.45 \%$ \\
\hline $\begin{array}{l}\text { Sharing knowledge is important, but one has to } \\
\text { prioritize other tasks given the limited amount of time } \\
\text { and budgets available to dedicate on their own } \\
\text { projects. }\end{array}$ & 5.156 & $73.83 \%$ \\
\hline $\begin{array}{l}\text { Knowledge sharing at the World Bank is a challenge } \\
\text { even when sufficient time and budgets are provided. }\end{array}$ & 4.719 & $63.28 \%$ \\
\hline $\begin{array}{l}\text { Sharing knowledge with colleagues does not benefit } \\
\text { one personally. }\end{array}$ & 2.918 & $17.58 \%$ \\
\hline
\end{tabular}




\begin{tabular}{|c|c|c|}
\hline $\begin{array}{l}\text { A career at the Bank is defined through the } \\
\text { knowledge one possesses. Giving that knowledge } \\
\text { away by sharing with other WB staff does not } \\
\text { necessarily align with one's own career interests. }\end{array}$ & 2.832 & $19.92 \%$ \\
\hline $\begin{array}{l}\text { The reality here is that everyone wants to win projects } \\
\text { for their own unit. There is no strong incentive in } \\
\text { sharing knowledge with other units. }\end{array}$ & 4.063 & $46.48 \%$ \\
\hline $\begin{array}{l}\text { Other WB staff rarely engage in this behavior because } \\
\text { they lack the time needed to prepare a proper } \\
\text { handover package. }\end{array}$ & 6.00 & $100.00 \%$ \\
\hline $\begin{array}{l}\text { Other WB staff rarely engage in this behavior because } \\
\text { there is no institutional guidance on how to prepare a } \\
\text { good handover package. }\end{array}$ & 6.29 & $100.00 \%$ \\
\hline $\begin{array}{l}\text { Other WB staff rarely engage in this behavior because } \\
\text { they are not sure who the successor is for their role. } \\
\text { Therefore, they do not see a point in preparing a } \\
\text { handover package that will be sent to a "black hole." }\end{array}$ & 4.86 & $57.14 \%$ \\
\hline $\begin{array}{l}\text { Other WB staff rarely engage in this behavior because } \\
\text { they need to prioritize their new project tasks instead } \\
\text { of focusing on handing over old project tasks. }\end{array}$ & 5.86 & $100.00 \%$ \\
\hline $\begin{array}{l}\text { Other WB staff rarely engage in this behavior because } \\
\text { there are no charge codes associated with the time } \\
\text { that they have to spend on preparing a handover } \\
\text { package. }\end{array}$ & 4.43 & $57.14 \%$ \\
\hline $\begin{array}{l}\text { Other WB staff rarely engage in this behavior because } \\
\text { they do not know how the successor likes to learn; } \\
\text { hence, their efforts may be ignored. They'd prefer to } \\
\text { leave it up to her or him to learn what is required of } \\
\text { the role on their own. }\end{array}$ & 3.86 & $42.86 \%$ \\
\hline $\begin{array}{l}\text { Other WB staff rarely engage in this behavior because } \\
\text { this should be the hiring manager's responsibility. } \\
\text { They are moving on to a new assignment and should } \\
\text { not be responsible for this task. }\end{array}$ & 3.14 & $42.86 \%$ \\
\hline $\begin{array}{l}\text { Other WB staff rarely engage in this behavior because } \\
\text { no one has ever prepared a good handover package } \\
\text { for them. Consequently, why should they bother } \\
\text { preparing a handover package for someone else? }\end{array}$ & 4.86 & $71.43 \%$ \\
\hline
\end{tabular}




\begin{tabular}{|c|c|c|}
\hline $\begin{array}{l}\text { Other WB staff rarely engage in this behavior because } \\
\text { they believe this should be the responsibility of } \\
\text { support staff/consultants/KM staff. They have other } \\
\text { urgent tasks to prioritize. }\end{array}$ & 3.86 & $42.86 \%$ \\
\hline $\begin{array}{l}\text { Other WB staff engage in this behavior because they } \\
\text { have worked on the project since the beginning and } \\
\text { want to see it succeed after they leave. }\end{array}$ & 5.00 & $71.43 \%$ \\
\hline $\begin{array}{l}\text { Other WB staff engage in this behavior because their } \\
\text { colleagues have ensured that they have received great } \\
\text { handover packages in the past when taking over their } \\
\text { projects. Therefore, they feel like they should do the } \\
\text { same for their colleagues. }\end{array}$ & 4.57 & $57.14 \%$ \\
\hline $\begin{array}{l}\text { Other WB staff engage in this behavior because } \\
\text { preparing a strong handover package will be } \\
\text { recognized by the institution. Therefore, they feel like } \\
\text { their career will benefit from completing this task. }\end{array}$ & 3.29 & $14.29 \%$ \\
\hline $\begin{array}{l}\text { Other WB staff engage in this behavior because it is } \\
\text { part of their responsibility as corporate citizens. }\end{array}$ & 4.14 & $42.86 \%$ \\
\hline $\begin{array}{l}\text { Other WB staff engage in this behavior because } \\
\text { preparing a handover package for their successor will } \\
\text { be recognized in their formal performance evaluation. }\end{array}$ & 3.57 & $42.86 \%$ \\
\hline $\begin{array}{l}\text { Other WB staff engage in this behavior because their } \\
\text { hiring manager asks them to prepare a handover } \\
\text { package for their successor, and they feel obliged to } \\
\text { follow these instructions. }\end{array}$ & 5.43 & $71.43 \%$ \\
\hline $\begin{array}{l}\text { Other WB staff engage in this behavior because they } \\
\text { believe that preparing a solid handover package is } \\
\text { something everyone at the Bank group should do in } \\
\text { order to effectively drive their mission forward. }\end{array}$ & 5.14 & $71.43 \%$ \\
\hline
\end{tabular}


TABLE 28: KDB1 handover package listing data

\begin{tabular}{|c|c|}
\hline Barriers & Drivers \\
\hline 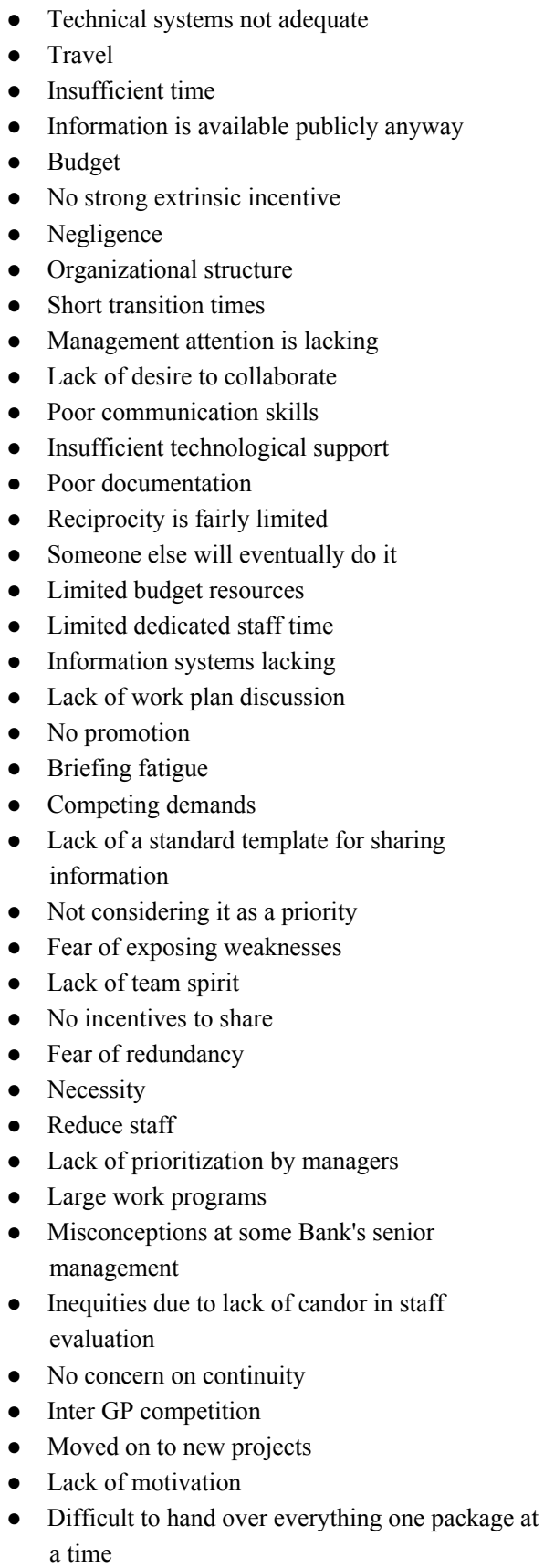 & 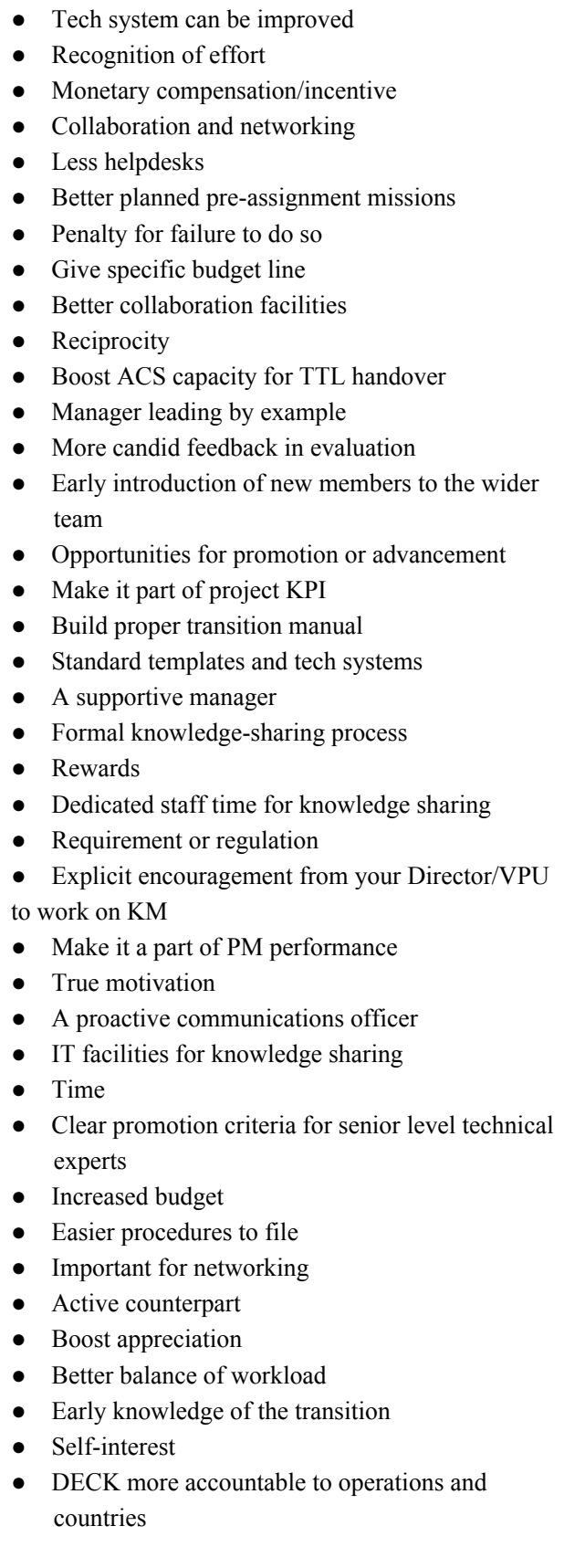 \\
\hline
\end{tabular}


- Little Co-TTL recognition for promotions

- Delaying until everything else is done

- More direct rewards needed

- Not enough role models

- Lack of cross GP collaboration

- Competition

- Personality hinders collaboration

- Lack of acknowledgment/recognition

- Lack of positive examples
- More creativity from Bank, i.e., innovate in social networks

- Sense of ownership

- Provide adequate ACS support

- Change silo culture

- More gatherings of staff

- Early introduction to the team/TTL taking over the task

- Oversight

- Include in OPE

\section{TABLE 29: KDB2 Joint Missions-Rating Data}

\begin{tabular}{|c|c|c|}
\hline Behavior Statement & Mean & $\%$ Agree \\
\hline $\begin{array}{l}\text { I often see other WB staff at the Bank engage in this } \\
\text { behavior. }\end{array}$ & 4.80 & $67.44 \%$ \\
\hline $\begin{array}{l}\text { I think other WB staff would feel a sense of } \\
\text { accomplishment if they were to engage in this } \\
\text { behavior. }\end{array}$ & 6.02 & $95.35 \%$ \\
\hline $\begin{array}{l}\text { I think that a sense of ownership a person has toward a } \\
\text { project incentivizes them to engage in this behavior. }\end{array}$ & 6.00 & $90.70 \%$ \\
\hline $\begin{array}{l}\text { I think the current technological systems in place } \\
\text { hinder other WB staff from engaging in this behavior. }\end{array}$ & 4.20 & $41.86 \%$ \\
\hline $\begin{array}{l}\text { I think that those who had a positive and useful } \\
\text { knowledge transfer experience in the past are more } \\
\text { likely to engage in this behavior. }\end{array}$ & 6.09 & $95.35 \%$ \\
\hline $\begin{array}{l}\text { I think other WB staff would be more likely to engage } \\
\text { in this behavior if the output would be more visible } \\
\text { (i.e., seen and recognized by a larger number of } \\
\text { colleagues). }\end{array}$ & 5.36 & $79.07 \%$ \\
\hline $\begin{array}{l}\text { I think other WB staff would be more likely to engage } \\
\text { in this behavior if their manager provided them with } \\
\text { sufficient time. }\end{array}$ & 5.68 & $88.37 \%$ \\
\hline $\begin{array}{l}\text { I think other WB staff would be more likely to engage } \\
\text { in this behavior if it were part of their performance } \\
\text { evaluation criteria. }\end{array}$ & 5.84 & $90.70 \%$ \\
\hline $\begin{array}{l}\text { I think other WB staff would be more likely to engage } \\
\text { in this behavior if others around them engaged in it. }\end{array}$ & 5.61 & $83.72 \%$ \\
\hline
\end{tabular}




\begin{tabular}{|c|c|c|}
\hline $\begin{array}{l}\text { I think other WB staff would be more likely to engage } \\
\text { in this behavior if it were tied to extrinsic rewards } \\
\text { (performance bonus and other monetary rewards). }\end{array}$ & 4.36 & $44.19 \%$ \\
\hline $\begin{array}{l}\text { I think other WB staff would be more likely to engage } \\
\text { in this behavior if it were tied to intrinsic rewards } \\
\text { (e.g., sense of accomplishment, social recognition, } \\
\text { sense of ownership, etc.). }\end{array}$ & 5.80 & $95.35 \%$ \\
\hline $\begin{array}{l}\text { Sharing knowledge about a project is important to } \\
\text { other WB staff because when they have worked on the } \\
\text { project from the beginning they want to see it succeed, } \\
\text { even if they are moving on to another role. }\end{array}$ & 6.11 & $97.67 \%$ \\
\hline $\begin{array}{l}\text { Sharing knowledge about one's project is motivated } \\
\text { by the fact that other World Bank colleagues share } \\
\text { their project knowledge as well. }\end{array}$ & 4.86 & $72.09 \%$ \\
\hline $\begin{array}{l}\text { Sharing knowledge about one's project with other } \\
\text { World Bank colleagues is important, even if other } \\
\text { colleagues do not share their knowledge. }\end{array}$ & 6.14 & $102.33 \%$ \\
\hline $\begin{array}{l}\text { Sharing knowledge is important, but one has to } \\
\text { prioritize other tasks given the limited amount of time } \\
\text { and budgets available to dedicate to their own projects. }\end{array}$ & 4.45 & $58.14 \%$ \\
\hline $\begin{array}{l}\text { Knowledge sharing at the World Bank is a challenge } \\
\text { even when sufficient time and budgets are provided. }\end{array}$ & 4.68 & $58.14 \%$ \\
\hline $\begin{array}{l}\text { Sharing knowledge with colleagues does not benefit } \\
\text { one personally. }\end{array}$ & 2.68 & $18.60 \%$ \\
\hline $\begin{array}{l}\text { A career at the Bank is defined through the knowledge } \\
\text { one possesses. Giving that knowledge away by sharing } \\
\text { with other WB staff does not necessarily align with } \\
\text { one's own career interests. }\end{array}$ & 2.91 & $25.58 \%$ \\
\hline $\begin{array}{l}\text { The reality here is that everyone wants to win projects } \\
\text { for their own unit. There is no strong incentive in } \\
\text { sharing knowledge with other units. }\end{array}$ & 3.91 & $44.19 \%$ \\
\hline $\begin{array}{l}\text { Other WB staff rarely engage in this behavior because } \\
\text { they do not know who their predecessor/successor is. }\end{array}$ & 3.83 & $34.78 \%$ \\
\hline
\end{tabular}




\begin{tabular}{|c|c|c|}
\hline $\begin{array}{l}\text { Other WB staff rarely engage in this behavior because } \\
\text { they think it's more cost effective to convey all } \\
\text { necessary handover information on the phone. }\end{array}$ & 3.35 & $26.09 \%$ \\
\hline $\begin{array}{l}\text { Outgoing WB staff rarely engage in this behavior } \\
\text { because by the time their successor arrives in their } \\
\text { former position they are already occupied with other } \\
\text { tasks that they have to prioritize. }\end{array}$ & 5.35 & $82.61 \%$ \\
\hline $\begin{array}{l}\text { Outgoing WB staff rarely engage in this behavior } \\
\text { because their new hiring manager does not provide } \\
\text { them with a budget code to complete a handover } \\
\text { mission for their old project. }\end{array}$ & 4.04 & $43.48 \%$ \\
\hline $\begin{array}{l}\text { Outgoing WB staff rarely engage in this behavior } \\
\text { because their new hiring manager does not provide } \\
\text { them with the extra time needed to go on a handover } \\
\text { mission for their old project. }\end{array}$ & 4.65 & $60.87 \%$ \\
\hline $\begin{array}{l}\text { Incoming WB staff rarely engage in this behavior as } \\
\text { they do not see a lot of value in conducting a joint } \\
\text { mission with their predecessor. }\end{array}$ & 3.17 & $21.74 \%$ \\
\hline $\begin{array}{l}\text { Incoming WB staff rarely engage in this behavior } \\
\text { because they typically cannot get hold of their } \\
\text { predecessor. They might reach out and never hear } \\
\text { back. }\end{array}$ & 3.65 & $34.78 \%$ \\
\hline $\begin{array}{l}\text { Incoming WB staff rarely engage in this behavior } \\
\text { because they typically cannot get ahold of their } \\
\text { predecessor. They might reach out but the predecessor } \\
\text { cannot find time for a joint mission. }\end{array}$ & 4.39 & $56.52 \%$ \\
\hline $\begin{array}{l}\text { Incoming WB staff rarely engage in this behavior } \\
\text { because it is easier for them to go on this mission } \\
\text { alone/with their new team mates. }\end{array}$ & 3.78 & $39.13 \%$ \\
\hline $\begin{array}{l}\text { Other WB staff engage in this behavior because they } \\
\text { have worked on the project/portfolio since the } \\
\text { beginning and want to see it succeed after they leave. }\end{array}$ & 5.83 & $91.30 \%$ \\
\hline $\begin{array}{l}\text { Other WB staff engage in this behavior because their } \\
\text { colleagues have offered joint missions to them in the } \\
\text { past when they were taking over their projects. } \\
\text { Therefore, they feel like they should do the same for } \\
\text { others. }\end{array}$ & 5.35 & $73.91 \%$ \\
\hline $\begin{array}{l}\text { Other WB staff engage in this behavior because going } \\
\text { on a joint mission will be recognized by the institution, } \\
\text { hence they feel like their career will benefit from } \\
\text { doing this. }\end{array}$ & 3.78 & $34.78 \%$ \\
\hline
\end{tabular}




\begin{tabular}{|l|l|l|}
\hline $\begin{array}{l}\text { Other WB staff engage in this behavior because it is } \\
\text { part of their responsibility as corporate citizens. }\end{array}$ & 4.87 & $65.22 \%$ \\
\hline $\begin{array}{l}\text { Other WB staff engage in this behavior because } \\
\text { whether they went on a joint mission with their } \\
\text { successor will be recognized in their formal } \\
\text { performance evaluation. }\end{array}$ & 3.61 & $30.43 \%$ \\
\hline $\begin{array}{l}\text { Other WB staff engage in this behavior because their } \\
\text { hiring manager asks them to go on a joint mission with } \\
\text { their successor and they feel that they should oblige. }\end{array}$ & 4.04 & $39.13 \%$ \\
\hline $\begin{array}{l}\text { Others engage in this behavior because they believe } \\
\text { that going on a joint mission is something everyone at } \\
\text { the Bank Group should do in order to effectively drive } \\
\text { their mission forward. }\end{array}$ & 5.17 & $65.22 \%$ \\
\hline
\end{tabular}

\section{TABLE 30: KDB2 Joint Missions-Rating Data}

\begin{tabular}{|c|c|}
\hline Barriers & Drivers \\
\hline 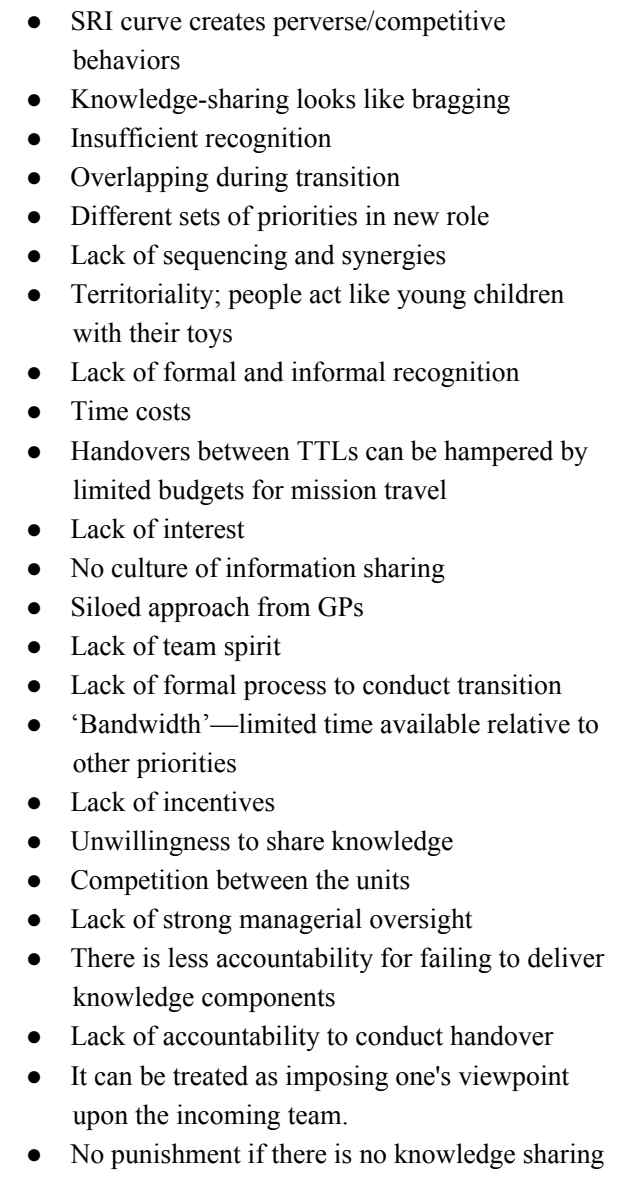 & 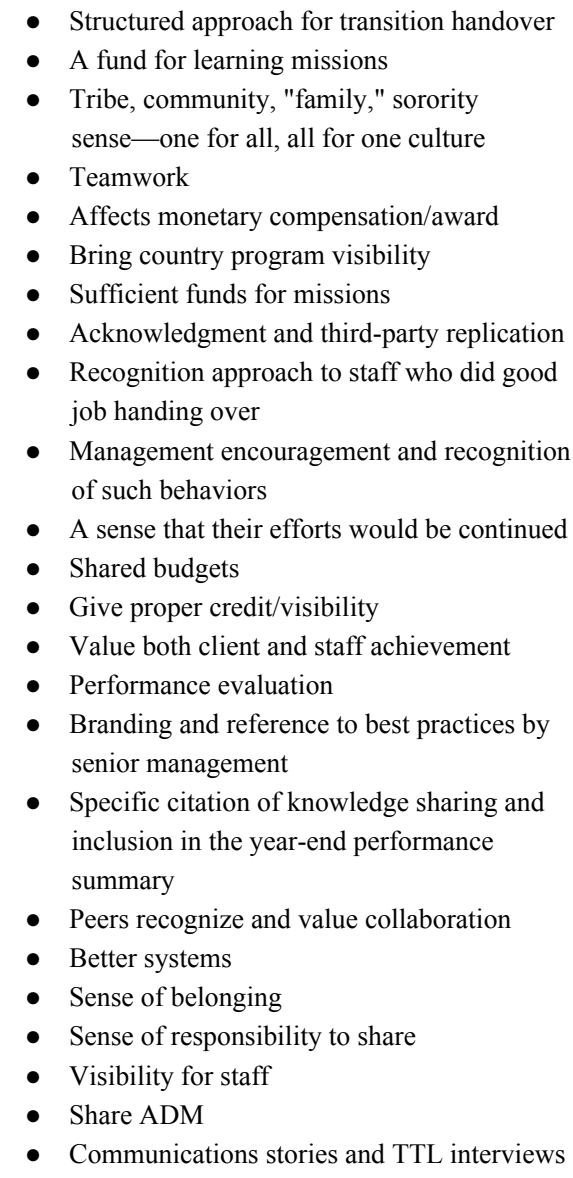 \\
\hline
\end{tabular}


- Undervaluing of knowledge sharing in professional evaluations/reputation

- Absence of a clear recording mechanism

- Lack of intrinsic motivation

- Knowledge resources are not monitored as seriously as investment resources

- Misalignment between performance objectives and knowledge sharing

- Organizational job insecurity triggering competitive and individualistic behaviors

- Insufficient time and skills to document learning systematically by self

- Greater emphasis at Bank on working on many different projects rather than doing fewer things well

- Fragmented approach

- Personal reasons that may keep people from traveling

- You worry that the knowledge you helped to create is of any use

- No formal knowledge-sharing protocols/guidelines of good practices
- Engaged team to be part of transition process

- Collaboration and knowledge sharing seen as integral to mentoring role

- Culture of openness and celebration of mistakes

- Compensation

- Sense of helping out as much as possible to colleagues

- Intrinsic motivation

- Career advancement

- Sense of ownership

- Recognition by management and peers

- Clear information sharing organizational rituals with associated incentives

- Making it part of OPE targets and professional development

- A working culture that recognizes all the people who contribute

- Willing to share one's knowledge

- Client expectation

- Generosity

- Spread awareness of own technical reputation

- Somewhere in OPE form to document it

\section{TABLE 31: KDB3 Top 10 Issues-Rating Data}

\begin{tabular}{|l|l|l|}
\hline Behavior Statement & Mean & \% Agree \\
\hline $\begin{array}{l}\text { I often see other WB staff at the Bank engage in this } \\
\text { behavior. }\end{array}$ & 3.30 & $21.88 \%$ \\
\hline $\begin{array}{l}\text { I think other WB staff would feel a sense of } \\
\text { accomplishment if they were to engage in this behavior. }\end{array}$ & 5.25 & $76.56 \%$ \\
\hline $\begin{array}{l}\text { I think that a sense of ownership a person has toward a } \\
\text { project incentivizes them to engage in this behavior. }\end{array}$ & 5.48 & $79.69 \%$ \\
\hline $\begin{array}{l}\text { I think the current technological systems in place hinder } \\
\text { other WB staff from engaging in this behavior. }\end{array}$ & 4.02 & $34.38 \%$ \\
\hline $\begin{array}{l}\text { I think that those who had a positive and useful } \\
\text { knowledge transfer experience in the past are more } \\
\text { likely to engage in this behavior. }\end{array}$ & 5.56 & $85.94 \%$ \\
\hline $\begin{array}{l}\text { I think other WB staff would be more likely to engage } \\
\text { in this behavior if the output would be more visible (i.e., } \\
\text { seen and recognized by a larger number of colleagues). }\end{array}$ & 5.45 & $79.69 \%$ \\
\hline $\begin{array}{l}\text { I think other WB staff would be more likely to engage } \\
\text { in this behavior if their manager provided them with } \\
\text { sufficient time. }\end{array}$ & 5.33 & $82.81 \%$ \\
\hline
\end{tabular}




\begin{tabular}{|c|c|c|}
\hline $\begin{array}{l}\text { I think other WB staff would be more likely to engage } \\
\text { in this behavior if it were part of their performance } \\
\text { evaluation criteria. }\end{array}$ & 5.61 & $81.25 \%$ \\
\hline $\begin{array}{l}\text { I think other WB staff would be more likely to engage } \\
\text { in this behavior if others around them engaged in it. }\end{array}$ & 5.53 & $84.38 \%$ \\
\hline $\begin{array}{l}\text { I think other WB staff would be more likely to engage } \\
\text { in this behavior if it were tied to extrinsic rewards } \\
\text { (performance bonus and other monetary rewards). }\end{array}$ & 5.00 & $65.63 \%$ \\
\hline $\begin{array}{l}\text { I think other WB staff would be more likely to engage } \\
\text { in this behavior if it were tied to intrinsic rewards (e.g., } \\
\text { sense of accomplishment, social recognition, sense of } \\
\text { ownership, etc.). }\end{array}$ & 5.34 & $79.69 \%$ \\
\hline $\begin{array}{l}\text { Sharing knowledge about a project is important to other } \\
\text { WB staff because when they have worked on the project } \\
\text { from the beginning they want to see it succeed, even if } \\
\text { they are moving on to another role. }\end{array}$ & 5.78 & $87.50 \%$ \\
\hline $\begin{array}{l}\text { Sharing knowledge about one's project is motivated by } \\
\text { the fact that other World Bank colleagues share their } \\
\text { project knowledge as well. }\end{array}$ & 4.73 & $60.94 \%$ \\
\hline $\begin{array}{l}\text { Sharing knowledge about one's project with other } \\
\text { World Bank colleagues is important, even if other } \\
\text { colleagues do not share their knowledge. }\end{array}$ & 5.73 & $89.06 \%$ \\
\hline $\begin{array}{l}\text { Sharing knowledge is important but one has to prioritize } \\
\text { other tasks given the limited amount of time and } \\
\text { budgets available to dedicate to their own projects. }\end{array}$ & 4.94 & $71.88 \%$ \\
\hline $\begin{array}{l}\text { Knowledge sharing at the World Bank is a challenge } \\
\text { even when sufficient time and budgets are provided. }\end{array}$ & 4.73 & $65.63 \%$ \\
\hline $\begin{array}{l}\text { Sharing knowledge with colleagues does not benefit one } \\
\text { personally. }\end{array}$ & 3.27 & $28.13 \%$ \\
\hline $\begin{array}{l}\text { A career at the Bank is defined through the knowledge } \\
\text { one possesses. Giving that knowledge away by sharing } \\
\text { with other WB staff does not necessarily align with } \\
\text { one's own career interests. }\end{array}$ & 3.02 & $23.44 \%$ \\
\hline $\begin{array}{l}\text { The reality here is that everyone wants to win projects } \\
\text { for their own unit. There is no strong incentive in } \\
\text { sharing knowledge with other units. }\end{array}$ & 4.45 & $57.81 \%$ \\
\hline $\begin{array}{l}\text { Outgoing WB staff rarely engage in this behavior } \\
\text { because they worked hard for possessing this } \\
\text { knowledge; their successor should make her/his own } \\
\text { experiences. }\end{array}$ & 3.17 & $21.43 \%$ \\
\hline
\end{tabular}




\begin{tabular}{|c|c|c|}
\hline $\begin{array}{l}\text { Outgoing WB staff rarely engage in this behavior } \\
\text { because they do not want to prime their successor. }\end{array}$ & 3.36 & $21.43 \%$ \\
\hline $\begin{array}{l}\text { Outgoing WB staff rarely engage in this behavior } \\
\text { because it is almost impossible to prioritize the top } 10 \\
\text { issues their successor should focus on. }\end{array}$ & 2.74 & $7.14 \%$ \\
\hline $\begin{array}{l}\text { Outgoing WB staff rarely engage in this behavior } \\
\text { because it is the first time they have heard of doing } \\
\text { this-they have not been advised/asked to do this } \\
\text { before. }\end{array}$ & 4.33 & $45.24 \%$ \\
\hline $\begin{array}{l}\text { Incoming WB staff rarely engage in this behavior } \\
\text { because they would not review such a list as it may } \\
\text { prime their thinking - it is important for them to create } \\
\text { their own picture of the situation and challenges. }\end{array}$ & 3.05 & $19.05 \%$ \\
\hline $\begin{array}{l}\text { Incoming WB staff rarely engage in this behavior } \\
\text { because it is more important to them to follow the } \\
\text { guidance of their new hiring manager instead of the } \\
\text { predecessor. }\end{array}$ & 4.00 & $45.24 \%$ \\
\hline $\begin{array}{l}\text { Incoming WB staff rarely engage in this behavior } \\
\text { because they are unsure of the level of performance and } \\
\text { reputation of their predecessor- - they prefer to start with } \\
\text { carte blanche or "clean slate." }\end{array}$ & 3.71 & $28.57 \%$ \\
\hline $\begin{array}{l}\text { Other WB staff engage in this behavior because they } \\
\text { have worked on the project/portfolio since the } \\
\text { beginning and want to see it succeed after they leave. }\end{array}$ & 5.40 & $80.95 \%$ \\
\hline $\begin{array}{l}\text { Other WB staff engage in this behavior because } \\
\text { colleagues have offered such lists to them in the past } \\
\text { when they were taking over their projects, hence they } \\
\text { feel like they should do the same for others. }\end{array}$ & 4.79 & $61.90 \%$ \\
\hline $\begin{array}{l}\text { Other WB staff engage in this behavior because creating } \\
\text { such a list will be recognized by the institution, hence } \\
\text { they feel like their career will benefit from doing this. }\end{array}$ & 3.83 & $33.33 \%$ \\
\hline $\begin{array}{l}\text { WB staff engage in this behavior because it is part of } \\
\text { their responsibility as corporate citizens. }\end{array}$ & 4.81 & $54.76 \%$ \\
\hline $\begin{array}{l}\text { Other WB staff engage in this behavior because whether } \\
\text { or not they created good documents for their successor } \\
\text { will be recognized in their formal performance } \\
\text { evaluation. }\end{array}$ & 3.43 & $26.19 \%$ \\
\hline
\end{tabular}




\begin{tabular}{|l|l|l|}
\hline $\begin{array}{l}\text { Other WB staff engage in this behavior because their } \\
\text { hiring manager asks them to create a list of top 10 } \\
\text { issues for their successor, and they feel that they should } \\
\text { oblige. }\end{array}$ & 4.62 & $52.38 \%$ \\
\hline $\begin{array}{l}\text { Others engage in this behavior because they believe that } \\
\text { creating a list of top } 10 \text { issues is something everyone at } \\
\text { the Bank Group should do in order to continue } \\
\text { effectively driving their mission forward. }\end{array}$ & 4.88 & $52.38 \%$ \\
\hline
\end{tabular}

\section{TABLE 32: KDB3 Top 10 Issues-Listing Data}

\begin{tabular}{|c|c|}
\hline Barriers & Drivers \\
\hline 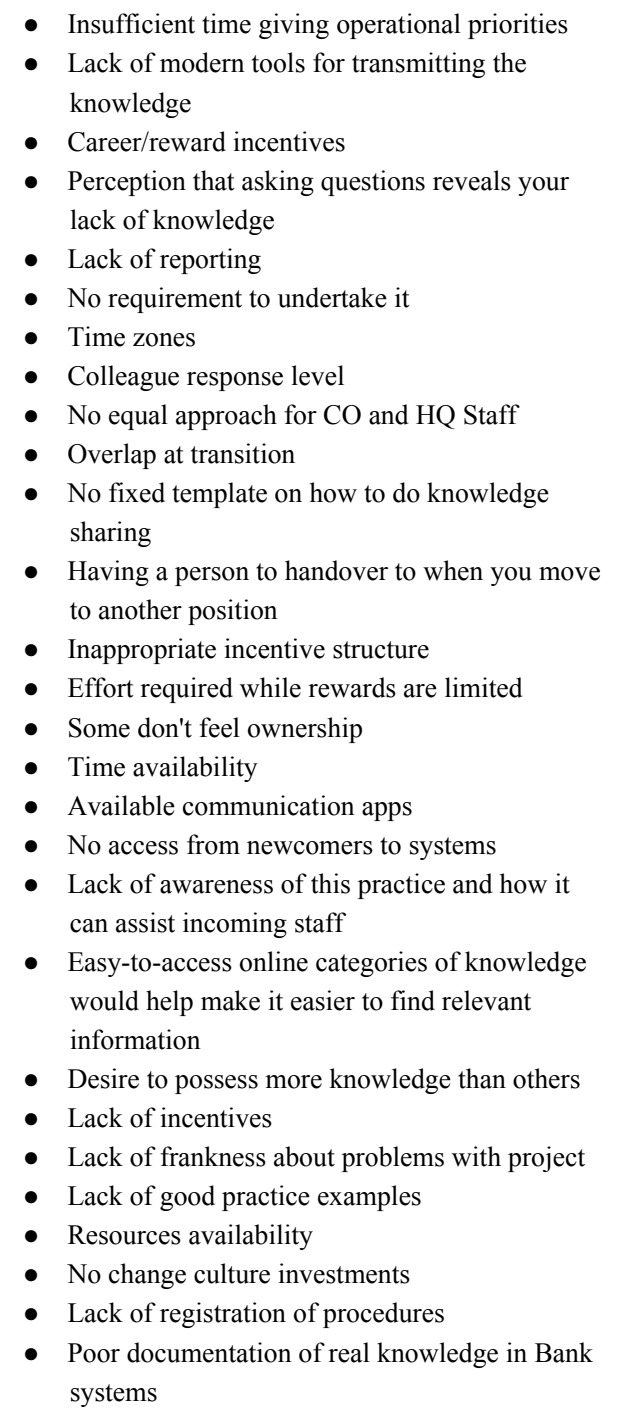 & 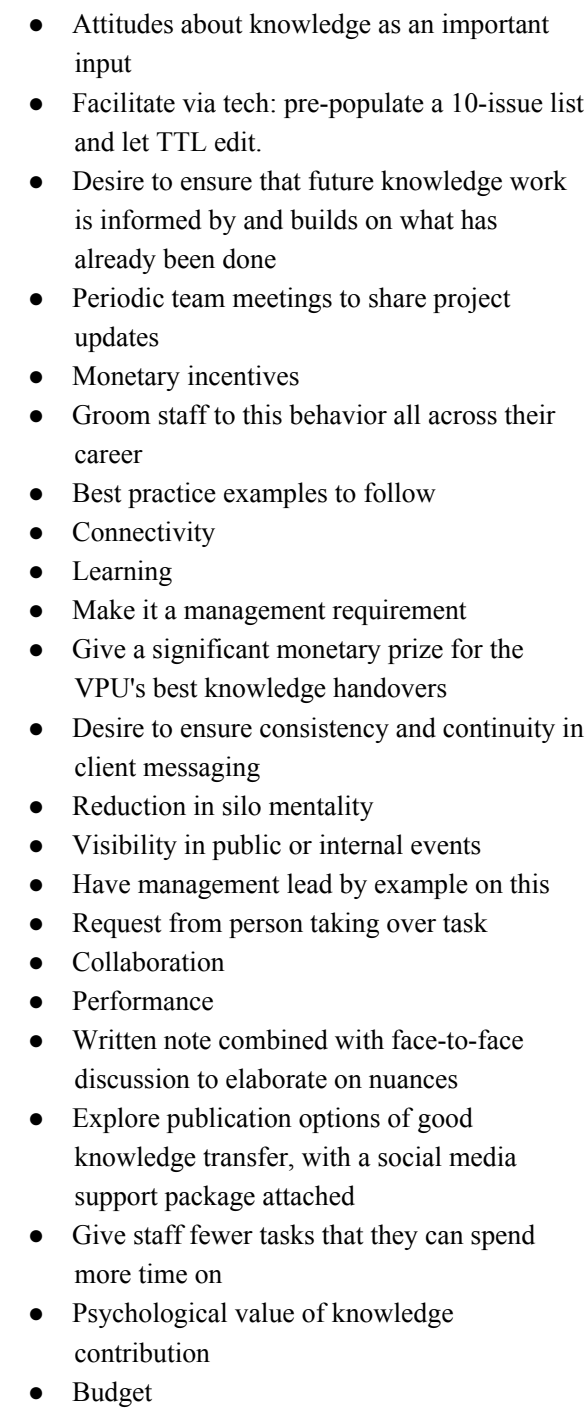 \\
\hline
\end{tabular}


- There is no systematic system of gathering knowledge

- Constant reliance on e-mail for communication across time zones

- Lack of recognition

- Not part of the normal handover, perceived as bureaucratic exercise

- Lack of sharing culture

- Lack of support staff

- No cushioning for overlap training

- No punishment for not doing it

- Lack of transmission mechanisms

- Limited intrinsic recognition, if at all

- Lack of awareness of who else could benefit from your knowledge

- Scarcity of budget

- WB not paying attention to transition plans

- Not linked with performance

- Lack of support platforms

- No standard approach

- No significant efforts have been made to realize knowledge sharing systematically

- Desire to seem indispensable

- Intranet search is so bad it is hard to do basic review of institutional experience

- Weak coordination among units/GPs

- Takes too much time

- Problems in country communication systems - connectivity

- Client issues
- Have an exit checklist

- Individual personality

- Respect

- Growing business

- Have managers give an annual award for knowledge sharing

- Career recognition

- Improve how all types of knowledge are captured and accessed

- Sense of ownership of twin goals

- Automated reporting

- Automated handover template

- Rewards for collaboration

- Take interest

- Recognition

- Have managers widely share knowledge-sharing examples

- Personal recognition

- Management signaling of openness to questions and open nonjudgmental discussion

- Youth are more prone to engage

- Collegiality

- System trigger to show they are ready for exit

- Create standard format for this knowledge sharing

- Propose and suggest

- Motivation

- Managers emphasize how important knowledge sharing is

- Allocate time for it

\section{TABLE 33: KDB4 Short Posts-Rating Data}

\begin{tabular}{|l|l|l|}
\hline Behavior Statement & Mean & \% Agree \\
\hline $\begin{array}{l}\text { I often see other WB staff at the Bank engage in this } \\
\text { behavior. }\end{array}$ & 4.17 & $51.85 \%$ \\
\hline $\begin{array}{l}\text { I think other WB staff would feel a sense of } \\
\text { accomplishment if they were to engage in this behavior. }\end{array}$ & 5.26 & $79.63 \%$ \\
\hline $\begin{array}{l}\text { I think that a sense of ownership a person has toward a } \\
\text { project incentivizes them to engage in this behavior. }\end{array}$ & 5.52 & $83.33 \%$ \\
\hline $\begin{array}{l}\text { I think the current technological systems in place hinder } \\
\text { other WB staff from engaging in this behavior. }\end{array}$ & 3.89 & $35.19 \%$ \\
\hline $\begin{array}{l}\text { I think that those who had a positive and useful } \\
\text { knowledge transfer experience in the past are more likely } \\
\text { to engage in this behavior. }\end{array}$ & 5.65 & $85.19 \%$ \\
\hline
\end{tabular}




\begin{tabular}{|c|c|c|}
\hline $\begin{array}{l}\text { I think other WB staff would be more likely to engage in } \\
\text { this behavior if the output would be more visible (i.e., } \\
\text { seen and recognized by a larger number of colleagues). }\end{array}$ & 5.74 & $87.04 \%$ \\
\hline $\begin{array}{l}\text { I think other WB staff would be more likely to engage in } \\
\text { this behavior if their manager provided them with } \\
\text { sufficient time. }\end{array}$ & 5.74 & $75.93 \%$ \\
\hline $\begin{array}{l}\text { I think other WB staff would be more likely to engage in } \\
\text { this behavior if it were part of their performance } \\
\text { evaluation criteria. }\end{array}$ & 5.63 & $81.48 \%$ \\
\hline $\begin{array}{l}\text { I think other WB staff would be more likely to engage in } \\
\text { this behavior if others around them engaged in it. }\end{array}$ & 5.63 & $90.74 \%$ \\
\hline $\begin{array}{l}\text { I think other WB staff would be more likely to engage in } \\
\text { this behavior if it were tied to extrinsic rewards } \\
\text { (performance bonus and other monetary rewards). }\end{array}$ & 5.19 & $70.37 \%$ \\
\hline $\begin{array}{l}\text { I think other WB staff would be more likely to engage in } \\
\text { this behavior if it were tied to intrinsic rewards (e.g., } \\
\text { sense of accomplishment, social recognition, sense of } \\
\text { ownership, etc.). }\end{array}$ & 5.56 & $79.63 \%$ \\
\hline $\begin{array}{l}\text { Sharing knowledge about a project is important to other } \\
\text { WB staff because when they have worked on the project } \\
\text { from the beginning they want to see it succeed, even if } \\
\text { they are moving on to another role. }\end{array}$ & 5.81 & $88.89 \%$ \\
\hline $\begin{array}{l}\text { Sharing knowledge about one's project is motivated by } \\
\text { the fact that other World Bank colleagues share their } \\
\text { project knowledge as well. }\end{array}$ & 4.76 & $61.11 \%$ \\
\hline $\begin{array}{l}\text { Sharing knowledge about one's project with other World } \\
\text { Bank colleagues is important, even if other colleagues do } \\
\text { not share their knowledge. }\end{array}$ & 5.70 & $88.89 \%$ \\
\hline $\begin{array}{l}\text { Sharing knowledge is important, but one has to prioritize } \\
\text { other tasks given the limited amount of time and budgets } \\
\text { available to dedicate to their own projects. }\end{array}$ & 5.67 & $85.19 \%$ \\
\hline $\begin{array}{l}\text { Knowledge sharing at the World Bank is a challenge } \\
\text { even when sufficient time and budgets are provided. }\end{array}$ & 5.04 & $77.78 \%$ \\
\hline $\begin{array}{l}\text { Sharing knowledge with colleagues does not benefit one } \\
\text { personally. }\end{array}$ & 2.87 & $16.67 \%$ \\
\hline $\begin{array}{l}\text { A career at the Bank is defined through the knowledge } \\
\text { one possesses. Giving that knowledge away by sharing } \\
\text { with other WB staff does not necessarily align with one's } \\
\text { own career interests. }\end{array}$ & 2.83 & $22.22 \%$ \\
\hline
\end{tabular}




\begin{tabular}{|c|c|c|}
\hline $\begin{array}{l}\text { The reality here is that everyone wants to win projects } \\
\text { for their own unit. There is no strong incentive in sharing } \\
\text { knowledge with other units. }\end{array}$ & 3.93 & $42.59 \%$ \\
\hline $\begin{array}{l}\text { Other WB staff rarely engage in this behavior because } \\
\text { they simply do not have time to do so. }\end{array}$ & 4.71 & $64.52 \%$ \\
\hline $\begin{array}{l}\text { Other WB staff rarely engage in this behavior because } \\
\text { they do not know which technology channels they should } \\
\text { use and don't want to spam their colleagues. }\end{array}$ & 4.52 & $61.29 \%$ \\
\hline $\begin{array}{l}\text { Other WB staff rarely engage in this behavior because } \\
\text { they are worried it may annoy some of their colleagues. }\end{array}$ & 3.77 & $32.26 \%$ \\
\hline $\begin{array}{l}\text { Other WB staff rarely engage in this behavior because } \\
\text { they are not always sure what their colleagues are } \\
\text { interested in. }\end{array}$ & 4.35 & $54.84 \%$ \\
\hline $\begin{array}{l}\text { Other WB staff rarely engage in this behavior as they do } \\
\text { not want to seem to be "imposing" their own views on to } \\
\text { their colleagues. }\end{array}$ & 3.65 & $38.71 \%$ \\
\hline $\begin{array}{l}\text { Other WB staff rarely engage in this behavior as they do } \\
\text { not know where to find "short, punchy and relevant" } \\
\text { stories that are easily shareable }\end{array}$ & 5.00 & $70.97 \%$ \\
\hline $\begin{array}{l}\text { Other WB staff engage in this behavior because they } \\
\text { have worked on the relevant project/portfolio since the } \\
\text { beginning and want to see it succeed. They believe the } \\
\text { knowledge they share helps their colleagues. }\end{array}$ & 5.35 & $83.87 \%$ \\
\hline $\begin{array}{l}\text { Other WB staff engage in this behavior because other } \\
\text { colleagues have offered such pieces to them in the past, } \\
\text { hence they feel like they should do the same for others. }\end{array}$ & 4.97 & $64.52 \%$ \\
\hline $\begin{array}{l}\text { Other WB staff engage in this behavior because sharing } \\
\text { such pieces will be recognized by the institution, hence } \\
\text { they feel like their career will benefit from doing this. }\end{array}$ & 4.65 & $61.29 \%$ \\
\hline $\begin{array}{l}\text { Other WB staff engage in this behavior because it is part } \\
\text { of their responsibility as corporate citizens. }\end{array}$ & 4.71 & $58.06 \%$ \\
\hline $\begin{array}{l}\text { Other WB staff engage in this behavior because whether } \\
\text { they share relevant knowledge with their colleagues will } \\
\text { be recognized in their formal performance evaluation. }\end{array}$ & 3.97 & $32.26 \%$ \\
\hline $\begin{array}{l}\text { Other WB staff engage in this behavior because they } \\
\text { believe that sharing relevant short pieces is something } \\
\text { everyone at the Bank group should do in order to } \\
\text { effectively drive their mission forward. }\end{array}$ & 5.16 & $70.97 \%$ \\
\hline
\end{tabular}




\begin{tabular}{|c|c|}
\hline Barriers & Privers \\
\hline 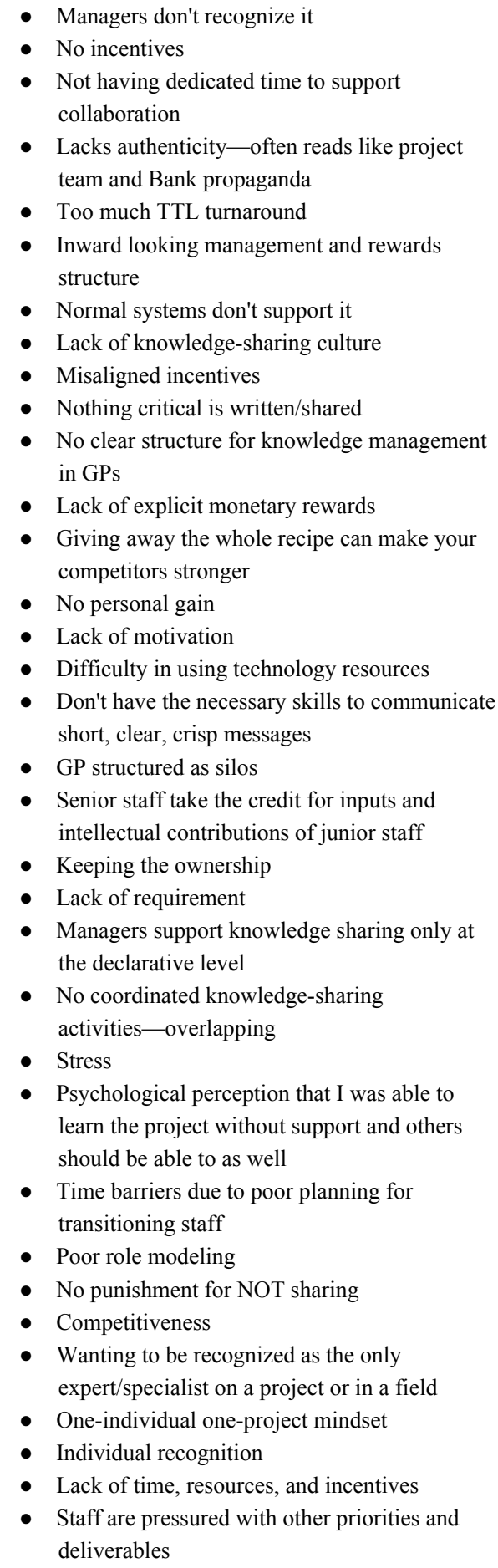 & 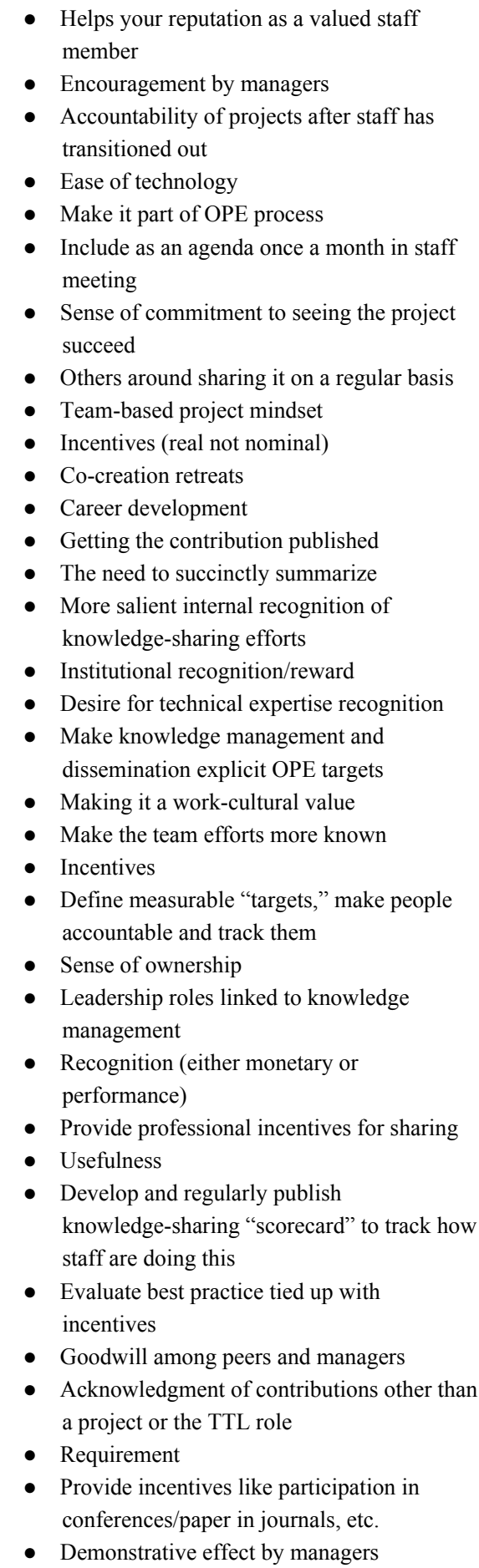 \\
\hline
\end{tabular}


TABLE 35: KDB5 Trainings-Rating Data

\begin{tabular}{|c|c|c|}
\hline Behavior Statement & Mean & $\%$ Agree \\
\hline $\begin{array}{l}\text { I often see other WB staff at the Bank engage in this } \\
\text { behavior. }\end{array}$ & 3.96 & $38.46 \%$ \\
\hline $\begin{array}{l}\text { I think other WB staff would feel a sense of } \\
\text { accomplishment if they were to engage in this } \\
\text { behavior. }\end{array}$ & 4.81 & $57.69 \%$ \\
\hline $\begin{array}{l}\text { I think that a sense of ownership a person has } \\
\text { toward a project incentivizes them to engage in this } \\
\text { behavior. }\end{array}$ & 5.52 & $78.85 \%$ \\
\hline $\begin{array}{l}\text { I think the current technological systems in place } \\
\text { hinder other WB staff from engaging in this } \\
\text { behavior. }\end{array}$ & 3.83 & $40.38 \%$ \\
\hline $\begin{array}{l}\text { I think that those who had a positive and useful } \\
\text { knowledge transfer experience in the past are more } \\
\text { likely to engage in this behavior. }\end{array}$ & 5.62 & $84.62 \%$ \\
\hline $\begin{array}{l}\text { I think other WB staff would be more likely to } \\
\text { engage in this behavior if the output would be more } \\
\text { visible (i.e., seen and recognized by a larger number } \\
\text { of colleagues). }\end{array}$ & 5.35 & $76.92 \%$ \\
\hline $\begin{array}{l}\text { I think other WB staff would be more likely to } \\
\text { engage in this behavior if their manager provided } \\
\text { them with sufficient time. }\end{array}$ & 5.29 & $76.92 \%$ \\
\hline $\begin{array}{l}\text { I think other WB staff would be more likely to } \\
\text { engage in this behavior if it were part of their } \\
\text { performance evaluation criteria. }\end{array}$ & 5.19 & $80.77 \%$ \\
\hline $\begin{array}{l}\text { I think other WB staff would be more likely to } \\
\text { engage in this behavior if others around them } \\
\text { engaged in it. }\end{array}$ & 5.29 & $82.69 \%$ \\
\hline $\begin{array}{l}\text { I think other WB staff would be more likely to } \\
\text { engage in this behavior if it were tied to extrinsic } \\
\text { rewards (performance bonus and other monetary } \\
\text { rewards). }\end{array}$ & 4.90 & $59.62 \%$ \\
\hline $\begin{array}{l}\text { I think other WB staff would be more likely to } \\
\text { engage in this behavior if it were tied to intrinsic } \\
\text { rewards (e.g., sense of accomplishment, social } \\
\text { recognition, sense of ownership, etc.). }\end{array}$ & 5.46 & $84.62 \%$ \\
\hline $\begin{array}{l}\text { Sharing knowledge about a project is important to } \\
\text { other WB staff because when they have worked on } \\
\text { the project from the beginning they want to see it } \\
\text { succeed, even if they are moving on to another role. }\end{array}$ & 5.75 & $88.46 \%$ \\
\hline $\begin{array}{l}\text { Sharing knowledge about one's project is motivated } \\
\text { by the fact that other World Bank colleagues share } \\
\text { their project knowledge as well. }\end{array}$ & 4.87 & $65.38 \%$ \\
\hline $\begin{array}{l}\text { Sharing knowledge about one's project with other } \\
\text { World Bank colleagues is important, even if other } \\
\text { colleagues do not share their knowledge. }\end{array}$ & 5.58 & $82.69 \%$ \\
\hline
\end{tabular}




\begin{tabular}{|c|c|c|}
\hline $\begin{array}{l}\text { Sharing knowledge is important, but one has to } \\
\text { prioritize other tasks given the limited amount of } \\
\text { time and budgets available to dedicate to their own } \\
\text { projects. }\end{array}$ & 5.60 & $82.69 \%$ \\
\hline $\begin{array}{l}\text { Knowledge sharing at the World Bank is a challenge } \\
\text { even when sufficient time and budgets are provided. }\end{array}$ & 4.42 & $51.92 \%$ \\
\hline $\begin{array}{l}\text { Sharing knowledge with colleagues does not benefit } \\
\text { one personally. }\end{array}$ & 2.79 & $9.62 \%$ \\
\hline $\begin{array}{l}\text { A career at the Bank is defined through the } \\
\text { knowledge one possesses. Giving that knowledge } \\
\text { away by sharing with other WB staff does not } \\
\text { necessarily align with one's own career interests. }\end{array}$ & 2.52 & $11.54 \%$ \\
\hline $\begin{array}{l}\text { The reality here is that everyone wants to win } \\
\text { projects for their own unit. There is no strong } \\
\text { incentive in sharing knowledge with other units. }\end{array}$ & 3.73 & $38.46 \%$ \\
\hline $\begin{array}{l}\text { Other WB staff rarely engage in this behavior } \\
\text { because they simply do not have time to do so. }\end{array}$ & 5.38 & $71.88 \%$ \\
\hline $\begin{array}{l}\text { Other WB staff rarely engage in this behavior } \\
\text { because they do not have a budget code for training } \\
\text { that lays outside the scope of their responsibilities. }\end{array}$ & 5.00 & $71.88 \%$ \\
\hline $\begin{array}{l}\text { Other WB staff rarely engage in this behavior } \\
\text { because they are unsure where to find training that } \\
\text { is of interest to them. }\end{array}$ & 4.38 & $50.00 \%$ \\
\hline $\begin{array}{l}\text { Other WB staff rarely engage in this behavior } \\
\text { because it does not add value to their career path. }\end{array}$ & 3.72 & $28.13 \%$ \\
\hline $\begin{array}{l}\text { Other WB staff rarely engage in this behavior } \\
\text { because there is enough to learn within their field of } \\
\text { specialty, which they need to prioritize. }\end{array}$ & 4.56 & $50.00 \%$ \\
\hline $\begin{array}{l}\text { Other WB staff engage in this behavior because it } \\
\text { allows them to connect better with their colleagues } \\
\text { from other sectors. }\end{array}$ & 5.25 & $84.38 \%$ \\
\hline $\begin{array}{l}\text { Other WB staff engage in this behavior because it } \\
\text { provides them with more credibility in the eyes of } \\
\text { their clients. }\end{array}$ & 4.75 & $53.13 \%$ \\
\hline $\begin{array}{l}\text { Other WB staff engage in this behavior because they } \\
\text { always like to learn about methods that can be } \\
\text { complementary to their own training. }\end{array}$ & 5.28 & $84.38 \%$ \\
\hline $\begin{array}{l}\text { Other WB staff engage in this behavior because } \\
\text { their own field of specialty does not always offer the } \\
\text { best solutions to the challenges they face. }\end{array}$ & 4.69 & $56.25 \%$ \\
\hline $\begin{array}{l}\text { Other WB staff engage in this behavior because } \\
\text { signing up for such trainings will be recognized by } \\
\text { the institution, hence they feel like their career will } \\
\text { benefit from doing this }\end{array}$ & 3.72 & $25.00 \%$ \\
\hline $\begin{array}{l}\text { Other WB staff engage in this behavior because it is } \\
\text { part of their responsibility as corporate citizens to } \\
\text { enrich their skills beyond what their specialty is. }\end{array}$ & 4.59 & $56.25 \%$ \\
\hline
\end{tabular}




\begin{tabular}{|l|l|l|}
\hline $\begin{array}{l}\text { Other WB staff engage in this behavior because } \\
\text { their hiring manager asks them to sign up for } \\
\text { training that falls outside the scope of their own } \\
\text { duties and responsibilities, and they feel that they } \\
\text { should oblige. }\end{array}$ & 3.69 & $25.00 \%$ \\
\hline $\begin{array}{l}\text { Other WB staff engage in this behavior because they } \\
\text { believe that signing up for extracurricular training is } \\
\text { something everyone at the Bank group should do in } \\
\text { order to continue effectively driving their mission } \\
\text { forward. }\end{array}$ & 4.69 & $59.38 \%$ \\
\hline
\end{tabular}

\section{TABLE 36: KDB5 Trainings-Listing Data}

\begin{tabular}{|c|c|}
\hline Barriers & Drivers \\
\hline 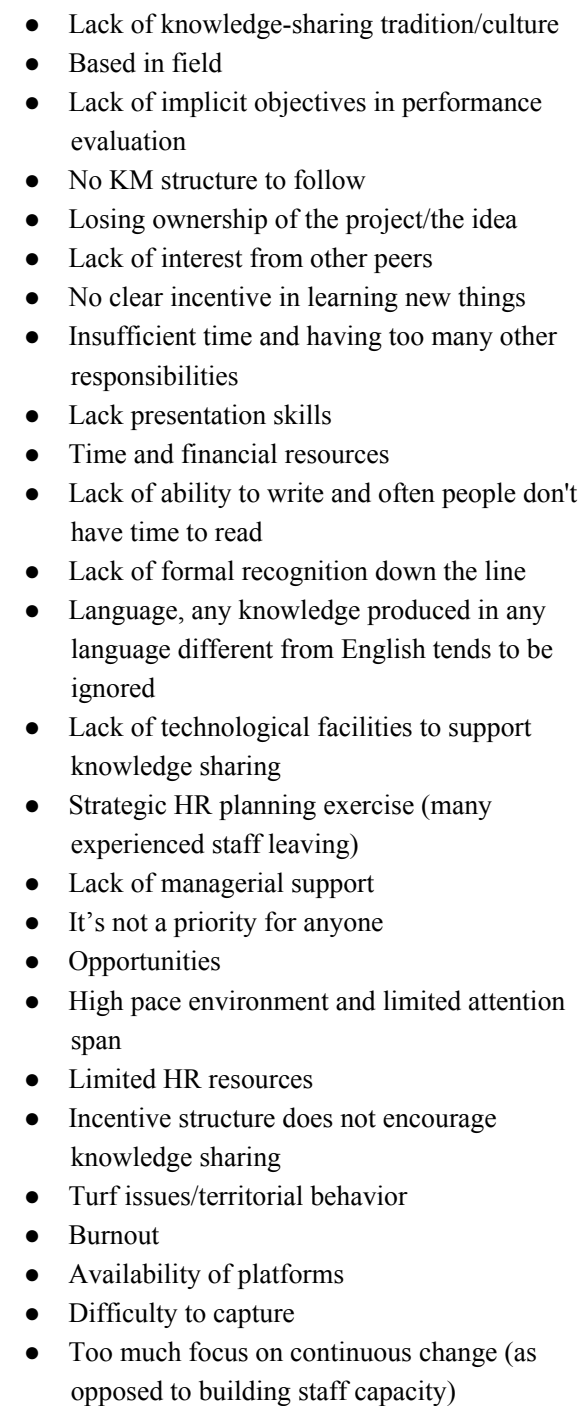 & 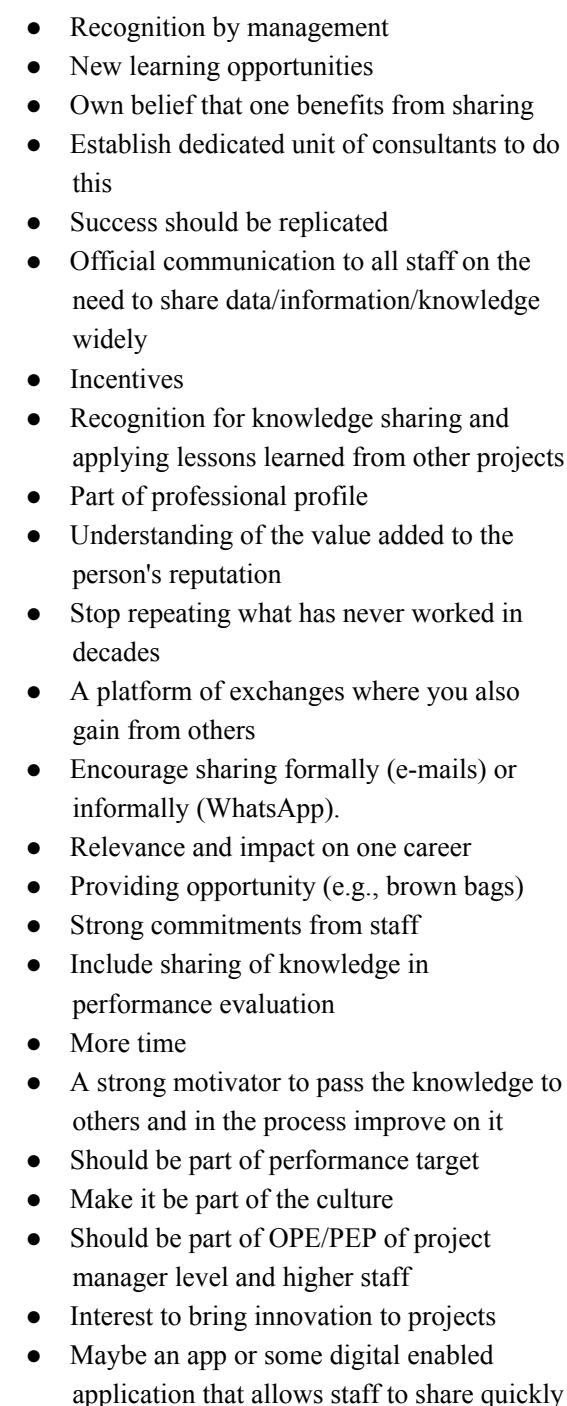 \\
\hline
\end{tabular}


- Management incentivize completion of products not dissemination

- Over programmed, not enough time to reflect and write or organize a KM event

- Fatigue

- Not part of performance evaluation

- Competing demands

- Lack of leadership from the top

- Silos

- Insecurity

- Overworked

- Managers are interested in starting new projects rather than knowledge sharing.

- Workload
- Genuine leadership

- Visibility

- Rewarding collaboration

- Innovate and make knowledge sharing easier

- Resources to screen and systematize knowledge in easily accessible way

- Interest to improve design by learning from others

- Clear metrics to measure knowledge sharing

- Behavioral changes from the top

- Ownership

- Promoting co-TTLship

- Rotate experienced staff through knowledge unit (DA)

- Desire to collaborate

- Make it easy for people to do it and hard to say no when asked

- Encouraging behavior of sharing and accepting mistakes as part of the learning process

- Ease of access

- Stressing on Corporate Mandate for Knowledge Production and Sharing 